Prepared in cooperation with the

Rhode Island Department of Health

\title{
Delineation and Prediction Uncertainty of Areas Contributing Recharge to Selected Well Fields in Wetland and Coastal Settings, Southern Rhode Island
}

Scientific Investigations Report 2010-5060

U.S. Department of the Interior

U.S. Geological Survey 
This page has been left blank intentionally. 


\section{Delineation and Prediction Uncertainty of Areas Contributing Recharge to Selected Well Fields in Wetland and Coastal Settings, Southern Rhode Island}

By Paul J. Friesz

Prepared in cooperation with the Rhode Island Department of Health

Scientific Investigations Report 2010-5060 


\title{
U.S. Department of the Interior \\ KEN SALAZAR, Secretary \\ U.S. Geological Survey \\ Marcia K. McNutt, Director
}

\section{U.S. Geological Survey, Reston, Virginia: 2010}

\begin{abstract}
For more information on the USGS — the Federal source for science about the Earth, its natural and living resources, natural hazards, and the environment, visit http://www.usgs.gov or call 1-888-ASK-USGS

For an overview of USGS information products, including maps, imagery, and publications, visit http://www.usgs.gov/pubprod

To order this and other USGS information products, visit http://store.usgs.gov
\end{abstract}

\begin{abstract}
Any use of trade, product, or firm names is for descriptive purposes only and does not imply endorsement by the U.S. Government.

Although this report is in the public domain, permission must be secured from the individual copyright owners to reproduce any copyrighted materials contained within this report.
\end{abstract}

Suggested citation:

Friesz, P.J., 2010, Delineation and prediction uncertainty of areas contributing recharge to selected well fields in wetland and coastal settings, southern Rhode Island: U.S. Geological Survey Scientific Investigations Report 2010-5060, 69 p. (Also available online at http://pubs.usgs.gov/sir/2010/5060.) 


\section{Contents}

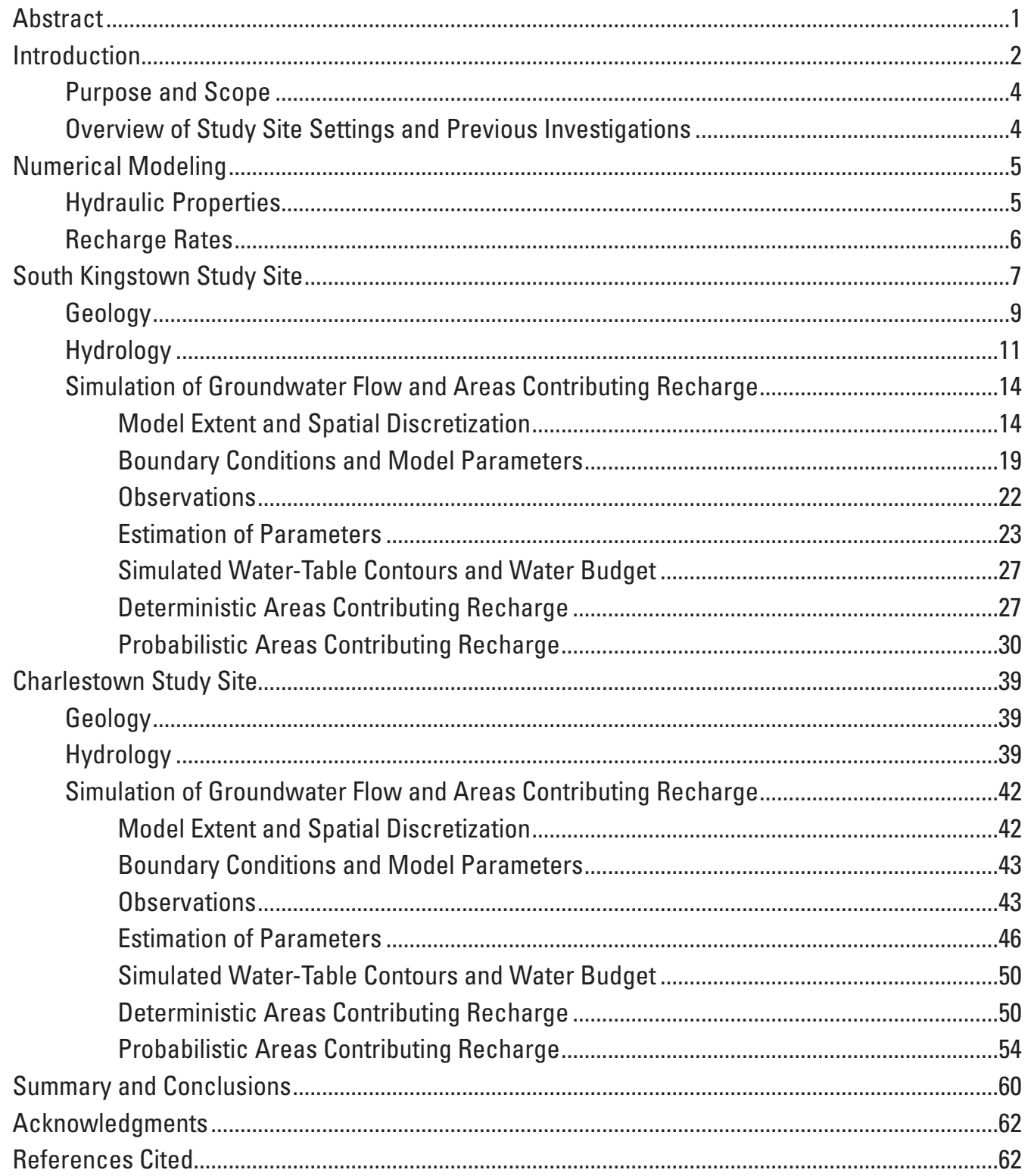

Appendix 1. Water depth, and thickness of peat and organic-rich sediment (location of profiles shown on figures 3 and 20), South Kingstown and Charlestown study sites, southern Rhode Island

Appendix 2. A, Stage of Worden Pond and B, stage of Tucker Pond and water levels in a pond-bottom piezometer, 2006-2008 (location of measurement sites shown on figure 3), South Kingstown study site, southern Rhode Island

Appendix 3. Streamflow measurements made at partial-record sites (location of partial-record sites shown on figures 3 and 20), South Kingstown and Charlestown study sites, southern Rhode Island 


\section{Figures}

1. Map showing study site well fields in South Kingstown and Charlestown, Rhode Island, and selected water-supply districts, U.S. Geological Survey (USGS) long-term network streamgages and observation wells, and a National Oceanic and Atmospheric Administration (NOAA) climatological station

2. Map showing production wells, section line, selected borings, model extent, bedrock-surface contours, and surficial geology, South Kingstown study site, southern Rhode Island. Bedrock-surface contours from Masterson and others (2007).

3. Map showing data-collection network near production wells, South Kingstown study site, southern Rhode Island.

4. Diagram showing geologic cross section, South Kingstown study site, southern Rhode Island.

5. Graph showing streamflow for the Beaver River streamgage (01117468) near Usquepaug, Rhode Island, during 1999-2008 (streamgage location shown on figure 1)

6. Graphs showing water levels measured in observation well CHW18 during 1951-60, 1988-92, and 1999-2008, Charlestown, Rhode Island (well location shown in figure 1)

7. Graph showing stage of wetland and water levels in piezometers screened in peat, and in sand and gravel near A, west well field and B, east well field, 2007-2008, South Kingstown study site, southern Rhode Island

8. Graph showing plot of drawdown with time compared to a Theis type curve and a leaky-aquifer type curve for a piezometer screened beneath the wetland near the east well field, March14-April 3, 2008, South Kingstown study site, southern Rhode Island

9. Map showing model-boundary types and observations, South Kingstown study site, southern Rhode Island

10. Graph showing composite scaled sensitivities for model parameters (parameter information is provided on table 2), South Kingstown study site, southern Rhode Island.

11. Graphs showing relation of $A$, weighted residual to weighted simulated equivalent and of $B$, weighted observation to weighted simulated equivalent, South Kingstown study site, southern Rhode Island.

12. Map showing spatial distribution of weighted residuals and simulated water-table contours for calibrated, steady-state conditions, South Kingstown study site, southern Rhode Island.

13. Map showing simulated areas contributing recharge to the United Water Rhode Island east and west well fields at their total average pumping rate of 2,138 gallons per minute, South Kingstown study site, southern Rhode Island.

14. Map showing simulated areas contributing recharge to the United Water Rhode Island east and west well fields at their total maximum pumping rate of 5,100 gallons per minute, South Kingstown study site, southern Rhode Island.

15. Map showing simulated traveltimes to the United Water Rhode Island well fields at their maximum pumping rate of 5,100 gallons per minute, South Kingstown study site, southern Rhode Island... 
16. Graphs showing frequency distribution of $A$, hydraulic parameters, and of $B$, recharge parameters, before acceptance criteria were applied to determine the probabilistic areas contributing recharge to the United Water Rhode Island well fields (parameter information is provided on table 2), South Kingstown study site, southern Rhode Island...

17. Graphs showing frequency distribution of $A$, hydraulic parameters, and of $B$, recharge parameters, after acceptance criteria were applied to determine the probabilistic areas contributing recharge to the United Water Rhode Island well fields (parameter information is provided on table 2), South Kingstown study site, southern Rhode Island

18. Map showing simulated probabilistic areas contributing recharge to the United Water Rhode Island well fields at their total average pumping rate of 2,138 gallons per minute, South Kingstown study site, southern Rhode Island.

19. Map showing simulated probabilistic areas contributing recharge to the United Water Rhode Island well fields at their total maximum pumping rate of 5,100 gallons per minute, South Kingstown study site, southern Rhode Island

20. Map showing production wells, section lines, selected borings, streamflow partial-record sites, model extent, bedrock-surface contours, and surficial geology, Charlestown study site, southern Rhode Island

21. Diagram showing geologic cross section, Charlestown study site, southern Rhode Island

22. Map showing model-boundary types and observations, Charlestown study site, southern Rhode Island.

23. Graph showing composite scaled sensitivities for model parameters (parameter information is provided on table 4), Charlestown study site, southern Rhode Island.....46

24. Graphs showing relation of $A$, weighted residual to weighted simulated equivalent, and of $B$, weighted observation to weighted simulated equivalent, Charlestown study site, southern Rhode Island.

25. Map showing spatial distribution of weighted residuals and simulated water-table contours for calibrated, steady-state conditions, Charlestown study site, southern Rhode Island

26. Map showing simulated areas contributing recharge to the Central Beach Fire District and East Beach Water Association well fields, at their total average pumping rate of 16 gallons per minute, Charlestown study site, southern Rhode Island

27. Map showing simulated areas contributing recharge to the Central Beach Fire District and East Beach Water Association well fields, at their total maximum pumping rate of 230 gallons per minute, Charlestown study site, southern Rhode Island

28. Map showing simulated traveltimes to the Central Beach Fire District and East Beach Water Association well fields at their maximum pumping rate of 230 gallons per minute, Charlestown study site, southern Rhode Island.

29. Graphs showing frequency distribution of $A$, hydraulic parameters, and of $B$, recharge parameters, before acceptance criteria were applied to determine the probabilistic areas contributing recharge to the Central Beach Fire District and East Beach Water Association well fields (parameter information is provided on table 4), Charlestown study site, southern Rhode Island. 
30. Map showing frequency distribution of $A$, hydraulic parameters, and of $B$, recharge parameters, after acceptance criteria were applied to determine the probabilistic areas contributing recharge to the Central Beach Fire District and East Beach Water Association well fields (parameter information is provided on table 4), Charlestown study site, southern Rhode Island.

31. Map showing simulated probabilistic areas contributing recharge to the Central Beach Fire District and East Beach Water Association well fields at their total average pumping rate of 16 gallons per minute, Charlestown study site, southern Rhode Island.....

32. Map showing simulated probabilistic areas contributing recharge to the Central Beach Fire District and East Beach Water Association well fields at their total maximum pumping rate of 230 gallons per minute, Charlestown study site, southern Rhode Island.

\section{Tables}

1. Characteristics of the production wells for the South Kingstown and Charlestown study sites, southern Rhode Island.

2. Definition of model parameters, optimal parameter value or specified value, and parameter-estimation statistics for the South Kingstown study site, southern Rhode Island.

3. Summary of the Monte Carlo analysis for the South Kingstown study site, southern Rhode Island.

4. Definition of model parameters, optimal parameter value or specified value, and parameter-estimation statistics for the Charlestown study site, southern Rhode Island

5. Summary of the Monte Carlo analysis for the Charlestown study site, southern Rhode Island. 
Conversion Factors, Datums, and Acronyms

\begin{tabular}{lcl}
\hline \multicolumn{1}{c}{ Multiply } & By & \multicolumn{1}{c}{ To obtain } \\
\hline inch (in.) & Length & \\
foot (ft) & 2.54 & centimeter $(\mathrm{cm})$ \\
mile $(\mathrm{mi})$ & 0.3048 & meter $(\mathrm{m})$ \\
\hline & 1.609 & kilometer $(\mathrm{km})$ \\
\hline square mile $\left(\mathrm{mi}^{2}\right)$ & Area & square $\mathrm{kilometer}\left(\mathrm{km}^{2}\right)$ \\
\hline & 2.590 & \\
\hline cubic foot per second $\left(\mathrm{ft}^{3} / \mathrm{s}\right)$ & Flow rate & cubic meter per second $\left(\mathrm{m}^{3} / \mathrm{s}\right)$ \\
gallon per minute $\left(\mathrm{gal} / \mathrm{min}^{2}\right)$ & 0.02832 & liter per second $(\mathrm{L} / \mathrm{s})$ \\
inch per year $(\mathrm{in} / \mathrm{yr})$ & 0.06309 & millimeter per year $\left(\mathrm{mm} / \mathrm{yr}^{2}\right)$ \\
\hline & 25.4 & meter per day $(\mathrm{m} / \mathrm{d})$ \\
\hline foot per day $(\mathrm{ft} / \mathrm{d})$ & Hydraulic conductivity & \\
\hline & 0.3048 & meter squared per day $\left(\mathrm{m}^{2} / \mathrm{d}\right)$ \\
\hline foot squared per day $\left(\mathrm{ft}^{2} / \mathrm{d}\right)$ & Transmissivity & \\
\hline
\end{tabular}

Temperature in degrees Fahrenheit $\left({ }^{\circ} \mathrm{F}\right)$ may be converted to degrees Celsius $\left({ }^{\circ} \mathrm{C}\right)$ as follows:

$$
{ }^{\circ} \mathrm{C}=\left({ }^{\circ} \mathrm{F}-32\right) / 1.8
$$

Vertical coordinate information is referenced to the National Geodetic Vertical Datum of 1929 (NGVD 29).

Horizontal coordinate information is referenced to the North American Datum of 1983 (NAD 83).

Specific conductance is given in microsiemens per centimeter at 25 degrees Celsius $\left(\mu \mathrm{S} / \mathrm{cm}\right.$ at $25^{\circ} \mathrm{C}$ )

\section{ACRONYMS}

CBFD Central Beach Fire District

EBWA East Beach Water Association

RIDEM Rhode Island Department of Environmental Management

RIDOH Rhode Island Department of Health

USGS U.S. Geological Survey

UWRI United Water Rhode Island 
This page has been left blank intentionally. 


\title{
Delineation and Prediction Uncertainty of Areas Contributing Recharge to Selected Well Fields in Wetland and Coastal Settings, Southern Rhode Island
}

\author{
By Paul J. Friesz
}

\section{Abstract}

Areas contributing recharge to four well fields in two study sites in southern Rhode Island were delineated on the basis of steady-state groundwater-flow models representing average hydrologic conditions. The wells are screened in sand and gravel deposits in wetland and coastal settings. The groundwater-flow models were calibrated by inverse modeling using nonlinear regression. Summary statistics from nonlinear regression were used to evaluate the uncertainty associated with the predicted areas contributing recharge to the well fields.

In South Kingstown, two United Water Rhode Island well fields are in Mink Brook watershed and near Worden Pond and extensive wetlands. Wetland deposits of peat near the well fields generally range in thickness from 5 to 8 feet. Analysis of water-level drawdowns in a piezometer screened beneath the peat during a 20-day pumping period indicated vertical leakage and a vertical hydraulic conductivity for the peat of roughly $0.01 \mathrm{ft} / \mathrm{d}$. The simulated area contributing recharge for average withdrawals of 2,138 gallons per minute during 2003-07 extended to groundwater divides in mostly till and morainal deposits, and it encompassed 2.30 square miles. Most of a sand and gravel mining operation between the well fields was in the simulated contributing area. For the maximum pumping capacity (5,100 gallons per minute), the simulated area contributing recharge expanded to 5.54 square miles. The well fields intercepted most of the precipitation recharge in Mink Brook watershed and in an adjacent small watershed, and simulated streams ceased to flow. The simulated contributing area to the well fields included an area beneath Worden Pond and a remote, isolated area in upland till on the opposite side of Worden Pond from the well fields. About 12 percent of the pumped water was derived from Worden Pond.

In Charlestown, the Central Beach Fire District and the East Beach Water Association well fields are on a small (0.85 square mile) peninsula in a coastal setting. The wells are screened in a coarse-grained, ice-proximal part of a morphosequence with saturated thicknesses generally less than 30 feet on the peninsula. The simulated area contributing recharge for the average withdrawal (16 gallons per minute) during 2003-07 was 0.018 square mile. The contributing area extended southwestward from the well fields to a simulated groundwater mound; it underlay part of a small nearby wetland, and it included isolated areas on the side of the wetland opposite the well fields. For the maximum pumping rate (230 gallons per minute), the simulated area contributing recharge ( 0.26 square mile) expanded in all directions; it included a till area on the peninsula, and it underlay part of a nearby pond. Because the well fields are screened in a thin aquifer, simulated groundwater traveltimes from recharge locations to the discharging wells were short: 94 percent of the traveltimes were 10 years or less, and the median traveltime was 1.3 years.

Model-prediction uncertainty was evaluated using a Monte Carlo analysis; the parameter variance-covariance matrix from nonlinear regression was used to create parameter sets for the analysis. Important parameters for model prediction that could not be estimated by nonlinear regression were incorporated into the variance-covariance matrix. For the South Kingstown study site, observations provided enough information to constrain the uncertainty of these parameters within realistic ranges, but for the Charlestown study site, prior information on parameters was required. Thus, the uncertainty analysis for the South Kingstown study site was an outcome of calibrating the model to available observations, but the Charlestown study site was also dependent on information provided by the modeler. A water budget and model-fit statistical criteria were used to assess parameter sets so that prediction uncertainty was not overestimated. For the scenarios using maximum pumping rates at both study sites where the well fields intercepted most of the precipitation recharge that would otherwise have discharged to nearby small streams, results from the probabilistic contributing area indicated that, generally, areas closer to the well fields with shorter traveltimes are associated with higher probabilities and are more likely to coincide with the deterministic contributing area than are areas farther from the well fields with longer 
traveltimes and associated with lower probabilities. For both the maximum pumping rates and for the average pumping rate at the South Kingstown study site, the deterministic contributing areas generally corresponded to areas associated with high probabilities (greater than 50 percent). For the average pumping rate in the South Kingstown study site, areas associated with low probabilities were not only distant from the well fields but were located where simulated streams in the calibrated model intercepted precipitation recharge, thus indicating that this recharge may instead go directly to a well. That part of the sand and gravel mining operation between the well fields that was not in the deterministic contributing area was in the probabilistic contributing area, including some areas associated with high probabilities. For the maximum pumping rate in the South Kingstown study site, some areas on the opposite side of Worden Pond from the well fields that were not in the deterministic contributing area were in the probabilistic contributing area, but mostly low probabilities were associated with such areas. For the average pumping rate in the Charlestown study site, areas associated with high probabilities were limited to the well-field side of a nearby wetland; the deterministic contributing area on this side of the wetland coincided with this area of high probabilities. For both pumping rates, areas associated with low probabilities extended through the middle of the peninsula toward the mainland; for the maximum pumping rate, the low probability areas included small, isolated areas on the mainland.

\section{Introduction}

Accurate delineation of areas contributing recharge to production wells is an important component of Federal, State, and local strategies for protecting drinking-water supplies from contamination (U.S. Environmental Protection Agency, 1991). The Source Water Assessment Program of the Rhode Island Department of Health (RIDOH), Office of Drinking Water Quality, was established by the 1996 Amendments to the Federal Safe Drinking Water Act. Since that time, RIDOH has assessed the susceptibility and risk of public-water supplies to contamination, and the agency encourages land-use planning within the areas contributing recharge to a production well. The Rhode Island Department of Environmental Management (RIDEM), Office of Water Resources, has determined areas contributing recharge to most production wells in Rhode Island, but RIDEM and RIDOH want to more accurately delineate areas contributing recharge to wells in complex hydrologic settings. Numerical groundwater-flow modeling, coupled with a particle-tracking technique, is a more advanced method for delineating areas contributing recharge than the analytical methods that have previously been used for this purpose.

The United Water Rhode Island (UWRI) well fields, in the Town of South Kingstown and near extensive wetlands, are an important groundwater supply in southern Rhode
Island (fig. 1). The UWRI well fields supply the second largest quantity of groundwater in the State (Emily Wild, U.S. Geological Survey, written commun. 2008). UWRI supplies water to about 30,000 people, more than half the combined population of the Towns of South Kingstown and Narragansett, either directly or indirectly, through South Kingstown Water District and Narragansett Water Division (fig. 1). Narragansett Water Division receives all of its water from UWRI. In 2005, a South Kingstown Water District well field was removed from service because of water-quality concerns, requiring this district also to receive all its water from UWRI and thereby increasing the demand for water from the enlarged population served. In the past, the UWRI wells have also been susceptible to water-quality issues. Pesticides from agriculture were detected in several of the UWRI wells, including a well that was removed from service from 1982 to 1988. Land use near the well fields includes a sand and gravel mining operation.

The well fields of the Central Beach Fire District (CBFD) and the East Beach Water Association (EBWA) are in a coastal setting in the Town of Charlestown, southern Rhode Island (fig. 1). The EBWA well field was reclassified as community wells in 2001. Both well fields are on a small peninsula where options for alternate supplies are limited. Water usage is expected to increase because of increased year-round residency and continued housing development. The well fields are screened in a shallow, unconfined aquifer generally less than $30-\mathrm{ft}$ thick where groundwater is relatively susceptible to contamination from activities on the land surface.

The U.S. Geological Survey (USGS), in cooperation with the RIDOH, began a 2-year study in 2006 to increase understanding of groundwater flow and of wetland-aquifer hydraulic connection at the South Kingstown and Charlestown study sites as part of an effort to protect the source of water to the well fields. This information also may be useful in delineation of areas contributing recharge to wells in other wetland and coastal settings in Rhode Island and other areas with similar geohydrologic settings. A numerical groundwaterflow model was designed for each study site and calibrated to hydrologic data by inverse modeling using nonlinear regression. Nonlinear regression estimates the optimal set of model-parameter values. In contrast to calibrating parameter values manually, summary statistics from nonlinear regression can be used to provide a quantitative measure of the uncertainty of the predictions, in this case, of its predictions for the size, location, and shape of the area contributing recharge to the well fields. The uncertainty that this study considers is from the observation dataset used for this calibration and not from the model design. Model design remains an unexplored source of uncertainty. Results of the calibrated model (used for a deterministic contributing area) and the uncertainty analysis (used for a probabilistic contributing area) in these complex settings could be useful to water-resource managers when they assess the risk of contamination and implement land-use plans. In addition, without an evaluation of the uncertainty associated with 

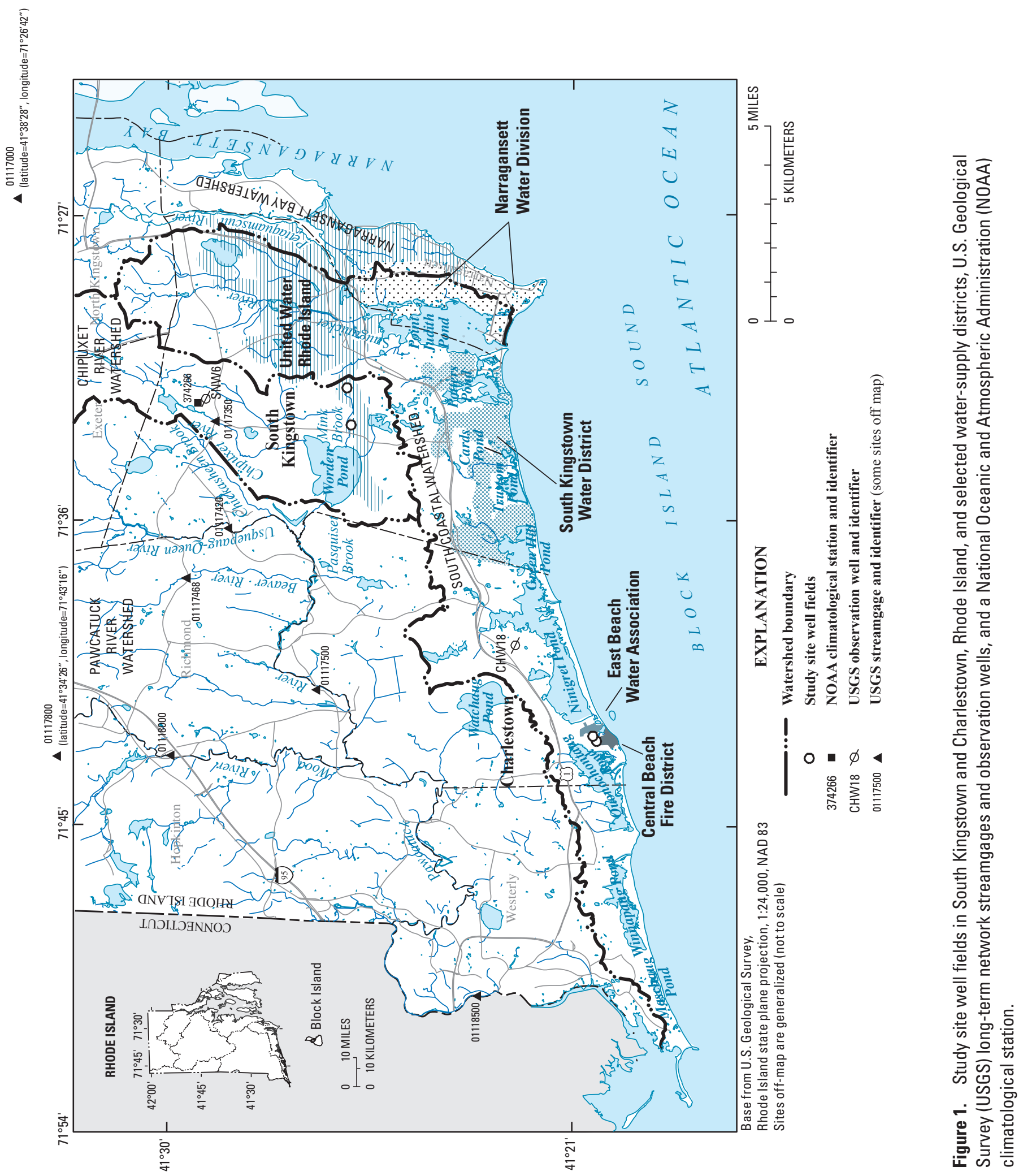
the model predictions, the area contributing recharge to a well may be underestimated, thereby leaving well fields inadequately protected.

The area contributing recharge to a well field based on the optimal set of parameter values from the calibrated model provides the best representation of the contributing area with the available observations. However, the parameter values are estimated with different levels of precision, and some important parameters for model predictions cannot always be estimated with available observations. An evaluation of uncertainty associated with the predicted contributing area was done using a stochastic Monte Carlo analysis. Multiple parameter sets for the Monte Carlo analysis were created using the parameter variance-covariance matrix from nonlinear regression, a method described and applied by Starn and others (2000). The present study applies the uncertainty analysis in different settings and with multiple well fields, exploring issues such as incorporating unestimated parameters into the analysis and assessing parameter sets so prediction uncertainty would not be overestimated.

\section{Purpose and Scope}

This report describes the geohydrology and the areas contributing recharge to 11 production wells in the two study sites of South Kingstown and Charlestown. The South Kingstown study site includes two UWRI well fields (7 wells), and the Charlestown study site includes the CBFD well field ( 2 wells) and the EBWA well field ( 2 wells). Numerical groundwater-flow models were developed and calibrated for each study site on the basis of geologic and hydrologic data collected during this and previous investigations. The groundwater-flow models were calibrated by inverse modeling using nonlinear regression to estimate the optimal set of parameter values. Simulated areas contributing recharge to the well fields based on the optimal set of parameter values (the deterministic contributing area) are shown on maps for selected pumping rates and average, steady-state hydrologic conditions. Summary statistics from nonlinear regression were used to evaluate the uncertainty associated with the predicted areas contributing recharge to the well fields. Issues such as incorporating unestimated parameters into the analysis and assessing parameter sets so prediction uncertainty would not be overestimated were explored. Maps depict the results of the uncertainty analysis of the simulated area contributing recharge expressed as a probability distribution.

Selected pumping rates include average withdrawals during 2003-07 and maximum-rated capacity of the production-well pumps. Maximum pumping rates used in the model simulations are not proposed, long-term (continuous) withdrawal rates. Instead, the simulated areas contributing recharge at these maximum rates are used by RIDOH for implementing land-use planning that protects the quality of the water that the production wells supply. Average withdrawals may change because of changes in water usage or changes in State policies. In addition, areas contributing recharge for the maximum pumping rate represent conservative, or larger, areas for land-use planning than for lower pumping rates.

\section{Overview of Study Site Settings and Previous Investigations}

The study sites in the Towns of South Kingstown and Charlestown are in southern Rhode Island (fig. 1) where the climate is humid and temperate. According to records from 1960 through 2007 for the Kingston (374266), Rhode Island, climatological station (National Oceanic and Atmospheric Administration, 2008) (fig. 1), average annual temperature is $50^{\circ} \mathrm{F}$ and average annual precipitation is 51 inches.

Groundwater at the study sites is stored and transmitted in surficial sediments of glacial origin - till, stratified, and morainal deposits - and in the underlying bedrock. A thin, discontinuous layer of till deposited directly on the bedrock by glacial ice is composed of a poorly sorted mixture of sediments ranging in size from clay to boulders. Stratified deposits consisting of well-sorted, layered sediments ranging in size from clay to gravel were deposited by glacial meltwater and overlie the till in the valleys and lowlands in coastal areas. Mixed sediments of till and stratified deposits are present in moraines, which formed at the ice margin when the retreating glacier paused for a period of time. Postglacial deposits of peat and alluvium locally overlie glacial deposits. The production wells are screened in coarse-grained stratified deposits composed of sand and gravel. Sand and gravel deposits, which have higher storage and transmissive properties than other geologic units, are the primary aquifers in Rhode Island.

The South Kingstown study site is characterized by wetlands, including Great Swamp, one of the largest wetlands in New England. The two UWRI well fields, about 0.8 miles apart and north of the Charlestown Moraine, are adjacent to a brook and associated wetlands in a small watershed of Worden Pond and Chipuxet River. These well fields are screened in thick saturated stratified deposits. Hydrologic and geologic information for this study site was available from regional USGS investigations. Bierschenk (1956) completed a reconnaissance study of groundwater conditions in the area that the USGS Kingston quadrangle covers, which includes the study site. The first comprehensive investigation of the groundwater and surface-water resources of the upper Pawcatuck River watershed, which includes the Chipuxet River watershed, was done by Allen and others (1966). An associated data report (Allen and others, 1963) compiled hydrologic and geologic data from this and the earlier study. Site-specific information from these regional investigations was available for the older production wells at the study site. Detailed mapping of the surficial deposits (Kaye, 1960) and of bedrock geology (Moore, 1964) has been done for the USGS Kingston quadrangle. 
The Charlestown study site is in a coastal setting. CBFD and EBWA well fields are south of the Charlestown Moraine near the center of a small $\left(0.85 \mathrm{mi}^{2}\right)$ peninsula bounded by Block Island Sound and by large saltwater ponds in the South Coastal watershed. The well fields are screened in thin and shallow saturated stratified deposits. Previous USGS investigations in the area covered by the USGS Quonochontaug and Carolina quadrangles, which include the study site, include reconnaissance of the groundwater conditions (LaSala, Jr., and Johnson, 1960; LaSala, Jr., and Hahn, 1960) and mapping of the bedrock geology (Moore, 1959). More recently, Masterson and others (2007) completed a regional study of geology and groundwater flow to saltwater ponds in the South Coastal watershed. This regional study included a manually calibrated groundwater-flow model. Relevant studies by other organizations include detailed mapping of the surficial deposits for the Quonochontaug and Carolina quadrangles (Boothroyd, 2001) and of groundwater conditions near the well fields (Urish, 1992, 2000).

\section{Numerical Modeling}

Many hydrologic features and processes may affect the size, shape, and location of the area contributing recharge to a well; this area is defined as the surface area where water recharges the groundwater and then flows toward and discharges to the well (Reilly and Pollock, 1993). Features and processes, such as groundwater systems with irregular geometry and complex lithology, or the interaction between individual pumping wells and hydrologic features such as surface-water bodies, are difficult to represent with analytical methods. Three-dimensional finite-difference numerical groundwater-flow models, however, can represent these and other geologic and hydrologic features and processes. Information provided by a numerical model on the source of water to a well can also be useful in protecting public health in Rhode Island.

Groundwater-flow models based on the finite-difference computer code MODFLOW-2000 (McDonald and Harbaugh, 1988; Harbaugh and others, 2000) and capable of simulating the response of the groundwater system to production-well withdrawals were developed for each of the two study sites. Model layers were simulated by using a fixed transmissivity, including the top layer, to linearize and thereby simplify the numerical calculations and to increase numerical stability. Fixed transmissivity was used because simulating thin layers on the sides of steeply sloping hills, such as near the upland-valley contact and the uplands themselves presents convergence difficulties for the model, as does the calibration by inverse modeling when using nonlinear regression.

Another advantage of using a fixed transmissivity is that it increases the number of model simulations that converge for the analysis of the probabilistic contributing area. Simplifying the numerical calculations by using a fixed transmissivity is described by DeSimone (2004) and Hill and Tiedeman (2007). A disadvantage of using fixed transmissivity for all model layers is that the simulated transmissivity of the aquifer does not change with drawdowns caused by different pumping rates than rates used in the calibrated model. Differences between using a fixed transmissivity and a variable transmissivity may include differences in hydraulic gradients, which may affect groundwater traveltimes and the response of surfacewater bodies to pumping, and thus potentially may affect the simulated area contributing recharge to a well.

Areas contributing recharge to the production wells were determined on the basis of model simulations of average, steady-state hydrologic conditions and by use of the particle-tracking program MODPATH (Pollock, 1994). The particle-tracking program calculates groundwater-flow paths and traveltimes on the basis of the head distribution computed by the groundwater-flow simulation. Areas contributing recharge were delineated by forward tracking of particles from recharging areas to the discharging wells. Particles were allowed to pass through model cells with weak sinks, which remove only a part of the water that flows into the cell. Pass-through weak-sink option was used because simulated contributing areas to a well may be larger and thus more conservative in terms of land-use protection than if the particles were stopped at weak sinks. Traveltimes in the groundwater-flow simulation do not take into account traveltime in the unsaturated zone between the land surface and the water table.

Development of a groundwater-flow model required that the geometry and hydraulic properties of the groundwater system and the fluxes into and out of the model be quantified. Each model was calibrated with the Parameter Estimation (inverse modeling) process of MODFLOW-2000 (Hill and others, 2000; Hill and Tiedeman, 2007) using nonlinear regression that minimizes the differences, or residuals, between field (observed) and simulated water levels and streamflows to obtain an optimal set of parameter values. Parameter values that nonlinear regression estimated for the model were compared to values reported in the literature in order to determine the reasonableness of the calibration. Literature values also were used to specify parameter values that could not be estimated by nonlinear regression, and in some cases, for prior information on model parameters to constrain uncertainty about the specified parameter values to reasonable ranges for model-prediction uncertainty. Reported values for hydraulic properties and recharge rates are summarized in two subsequent sections.

\section{Hydraulic Properties}

Glacial Deposits: The hydraulic properties of glacial till are highly variable. Aquifer tests and laboratory measurements indicated that hydraulic conductivity values for till in southern Rhode Island range from 0.07 to $41 \mathrm{ft} / \mathrm{d}$ with a median of $0.7 \mathrm{ft} / \mathrm{d}$ (Allen and others, 1966). Melvin and others (1992) 
summarized the hydraulic properties of till from previous studies in southern New England: for till derived from crystalline bedrock, horizontal hydraulic conductivities ranged from 0.004 to $65 \mathrm{ft} / \mathrm{d}$, and vertical hydraulic conductivities ranged from 0.013 to $96 \mathrm{ft} / \mathrm{d}$. Porosity values determined from a limited number of measurements in southern Rhode Island by Allen and others (1963) ranged from 0.23 to 0.50 and averaged 0.30 . Porosity values from a limited number of measurements in southern New England ranged from 0.22 to 0.41 and averaged 0.33 (Melvin and others, 1992).

Hydraulic conductivity values of glacial stratified deposits have been estimated from lithology and from aquifertest results. Values determined from lithology were based on the relation between horizontal hydraulic conductivity and grain size as determined by Rosenshein and others (1968) and modified by Dickerman (1984) from aquifer-test results in central Rhode Island. These values are $20 \mathrm{ft} / \mathrm{d}$ for very fine sand, $50 \mathrm{ft} / \mathrm{d}$ for fine sand, $100 \mathrm{ft} / \mathrm{d}$ for sand, $200 \mathrm{ft} / \mathrm{d}$ for sand and gravel, and $500 \mathrm{ft} / \mathrm{d}$ for gravel. The ratios of horizontal hydraulic conductivity to vertical hydraulic conductivity ranged from 2 to 80 on the basis of aquifer-test analyses in southern Rhode Island by Dickerman (1984) and by Dickerman and others (1990), averaging 6 and 10 in these studies, respectively. The porosities of 24 stratified sediment samples in southern Rhode Island reported by Allen and others (1963) ranged from 0.26 to 0.42 with an average value of 0.34. LeBlanc (1987) reported a range of porosities from 0.35 to 0.40 for stratified deposits in western Cape Cod, Massachusetts.

Few data are available for hydraulic properties of morainal deposits. Because morainal deposits in southern Rhode Island are composed of a mix of sandy ablation till and stratified deposits, bulk hydraulic properties most likely lie between properties of these two materials. Laboratory measurements indicated that hydraulic-conductivity values for morainal deposits in southern Rhode Island range from 0.1 to $13 \mathrm{ft} / \mathrm{d}$ (Allen and others, 1966). Values determined by manual calibration of groundwater-flow models ranged from 5 to $30 \mathrm{ft} / \mathrm{d}$ (Friesz, 2004; Masterson and others, 2007).

Post-glacial deposits: The interaction between streams and groundwater requires a conductance term that incorporates the geometry and the vertical hydraulic conductivity of the streambed. Bed sediments are typically alluvial deposits. Reported values for vertical hydraulic conductivity ranged from 0.1 to $17 \mathrm{ft} / \mathrm{d}$ for bed sediments in Rhode Island (Rosenshein and others, 1968; Gonthier and others, 1974; Johnston and Dickerman, 1974) and Massachusetts (Lapham, 1989; de Lima, 1991; Friesz, 1996; Friesz and Church, 2001). The vertical hydraulic conductivity of coarse-grained sediments in these studies typically ranged from 1 to $3 \mathrm{ft} / \mathrm{d}$ and from 0.1 to $0.7 \mathrm{ft} / \mathrm{d}$ for fine-grained sediments.

Wetland deposits consist of peat —organic matter in various stages of decomposition. Verry and Boelter (1979) reported hydraulic-conductivity values for peat from an extensive study in Minnesota that varied over several orders of magnitude, from less than $0.03 \mathrm{ft} / \mathrm{d}$ to more than $4 \mathrm{ft} / \mathrm{d}$, and with depth; in general, shallow, loose peat consisting of recent deposits with large interconnected pore spaces had higher values of hydraulic conductivity, and highly decomposed compact peat with small pore spaces at greater depths had lower values. For wetlands in eastern Massachusetts, O'Brien (1977) reported hydraulic-conductivity values ranging from 0.2 to $58 \mathrm{ft} / \mathrm{d}$. In a large wetland in southwestern Rhode Island, peat deposits averaged $0.3 \mathrm{ft} / \mathrm{d}$ (Friesz, 2004). Conceptually, most water in a wetland moves over the surface and through permeable shallow peat, whereas decomposed peat at depth impedes vertical flow. Peat generally has at least 80 percent porosity (Verry and Boelter, 1979).

Bedrock: Hydraulic conductivity and porosity of crystalline bedrock are generally low. Analysis of specificcapacity data from bedrock wells in eastern Connecticut indicated an average hydraulic conductivity of $0.5 \mathrm{ft} / \mathrm{d}$ (Randall and others, 1966). Lower values of 0.02 and $0.09 \mathrm{ft} / \mathrm{d}$ for crystalline bedrock in northern New Hampshire were determined through model calibration (Tiedeman and others, 1997). Porosity values for crystalline rock summarized in Meinzer (1923) range from 0.0002 to 0.02 .

\section{Recharge Rates}

Glacial deposits: Recharge in upland till areas is primarily from direct infiltration of precipitation, but it may also include leakage from streams, ponds, and wetlands. Recharge rates in upland settings are not well understood and conceptually are highly variable, ranging from near zero in low-permeability tills on steep topography, where the water table is near the land surface, to values approaching mean annual runoff (precipitation minus evapotranspiration) in sandy tills on moderate slopes, where the water table is perennially below the land surface. The application of a mathematical relation derived from Connecticut streamflow records and geology indicated that groundwater discharge, a measure of effective recharge (groundwater recharge minus groundwater evapotranspiration), is about 35 percent of mean annual runoff for till areas (Mazzaferro and others, 1979). Computerized hydrograph-separation techniques for longterm streamflow records from southeastern Rhode Island and Connecticut and from western Massachusetts for watersheds covered predominantly by till ( 90 percent or greater) indicated effective recharge rates ranging from 16 to $24 \mathrm{in} / \mathrm{yr}$ when mean annual runoff ranged from 27 to $31 \mathrm{in} / \mathrm{yr}$ (Bent, 1995, 1999; Friesz and Stone, 2007).

Sources of recharge to stratified deposits in a valleyfill setting include direct infiltration of precipitation, runoff from adjacent upland hillslopes, and natural infiltration from streams, ponds, and wetlands. In some cases, pumping by wells may also induce water from surface-water bodies. Conceptually, overland runoff is minimal in areas of stratified deposits, and recharge rates from direct infiltration of precipitation should approximate mean annual runoff rates (Lyford and Cohen, 1988). Mean annual streamflow from 
eight USGS long-term streamgages in southern Rhode Island (fig. 1) ranges from 26.8 to $32.8 \mathrm{in} / \mathrm{yr}$ over their watersheds. These rates are an average over the entire watershed, including areas of mostly stratified deposits but also areas of till, morainal deposits, surface-water bodies, wetlands, and a variety of land uses. The average and median of the mean annual streamflow for the eight streamgages are both $29.1 \mathrm{in} / \mathrm{yr}$. No studies have been done on recharge rates to morainal deposits in southern Rhode Island, but recharge rates may be nearly the same as recharge rates to stratified deposits because morainal deposits consist of mostly permeable coarsegrained sediments.

Wetlands: The role of wetlands in the hydrologic cycle is complex (Mitsch and Gosselink, 1993). Surface water in a wetland may be year-round or intermittent. Wetlands may serve as groundwater discharge areas or as recharge areas, or vary seasonally. Under pumping conditions, water that may have flowed across the surface may be induced to flow into the aquifer and then be withdrawn by the well. To account for all the water potentially available to the production wells under various pumping scenarios, water available for recharge (precipitation minus evapotranspiration) was applied to the wetlands. Evapotranspiration rates in wetlands are poorly defined. Some studies indicate that evapotranspiration rates from wetlands are higher than evaporation rates from open-water bodies, but other studies indicate that evapotranspiration rates are lower (Mitsch and Gosselink, 1993). Evapotranspiration rates measured in wetlands in eastern Massachusetts range from 21 to $40 \mathrm{in} / \mathrm{yr}$ (O'Brien, 1977; Hemond, 1980). For a precipitation rate of $51 \mathrm{in} / \mathrm{yr}$ in southern Rhode Island, the estimated water available for recharge over the wetlands would range from 11 to $30 \mathrm{in} / \mathrm{yr}$ using these evapotranspiration rates.

\section{South Kingstown Study Site}

UWRI production wells are clustered in two well fields in Mink Brook watershed, a small subbasin of Worden Pond and the Chipuxet River in the Town of South Kingstown, southern Rhode Island (figs. 1 and 2). The production wells are in the southeast part of Chipuxet River watershed near the boundary with the South Coastal watershed; most of this watershed boundary is in relatively transmissive materials where groundwater divides may not coincide with surfacewater divides. The study area extends to features that serve as hydrologic boundaries in the numerical model and which minimize the effects of model boundaries on simulated heads near any groundwater divides. These boundaries include rivers and streams in the north and northeast and coastal ponds and Block Island Sound in the southeast and south. In the west, the study area extends to topographical divides in upland till where groundwater and surface-water divides are most likely the same and in small areas of stratified deposits between upland till, where topographical divides are assumed to be the same, and northward from Factory Pond to upland till parallel to groundwater flow, based on a water-table map drawn by Bierschenk (1956) with water-level accuracies of about $\pm 5 \mathrm{ft}$. The production wells adjoin wetlands, with additional wetlands south and southwest of the wells, and with Great Swamp north of Worden Pond. Additional land uses in and near Mink Brook watershed include forest, agriculture, rural residential, developed recreation, and sand and gravel mining operations, one of which is midway between the well fields.

The UWRI well fields consist of seven wells; characteristics of the production wells are listed in table 1 . The production wells are screened in a coarse-grained sediment unit with saturated thicknesses of about $70 \mathrm{ft}$ at the east well field and greater than $100 \mathrm{ft}$ at the west well field. The east well field consists of four wells, three of which have been withdrawing water since the 1940s. Areas contributing recharge for this well field were determined for the 2003-07 average well-field withdrawal rate $(658 \mathrm{gal} / \mathrm{min})$ and the maximum well-field pumping capacity $(2,700 \mathrm{gal} / \mathrm{min})$. The west well field, which began withdrawing water in 1966, consists of three wells. The third well, approved for operation by the State during this study in 2006, was installed to complement operation of the existing two wells rather than to increase total withdrawals from the well field (Richard Amirault, Rhode Island Department of Health, written commun., 2007). Areas contributing recharge for this well field were determined for the 2003-07 average well-field pumping rate $(1,480 \mathrm{gal} / \mathrm{min})$ and for the maximum rate of the two highest maximum pumping capacities of the three wells $(2,400 \mathrm{gal} / \mathrm{min})$. Maximum pumping rates for each well were determined by distributing that maximum rate sum of $2,400 \mathrm{gal} / \mathrm{min}$ equally among the three wells composing the well field.

Most water withdrawn by the UWRI well fields is exported out of the Chipuxet River watershed to the South Coastal and Narragansett Bay watersheds (Wild and Nimiroski, 2005) (fig. 1). Most of this exported water is either used in sewered areas and then is treated at wastewater facilities before discharging to Narragansett Bay or it is returned to groundwater through private septic systems outside of the modeled area. Both the remaining exported water and the water used in the Chipuxet River watershed are returned to groundwater through private septic systems. In the Chipuxet River watershed, this is a small, mostly rural, residential area. About 85 percent of the water used by domestic population on septic systems is returned to groundwater, and 15 percent is consumed (Wild and Nimiroski, 2005).

Water levels and streamflows were measured periodically from October 2006 to October 2008 to increase understanding of interactions between surface water and groundwater and to provide information about average hydrologic conditions. The data-collection network (fig. 3) included a nest of vertical piezometers installed in the peat and in underlying sediments in the vicinity of each well field, a pond-bottom piezometer in Tucker Pond, five existing observation wells, and six pondand stream-stage sites. Streamflow measurements were made 


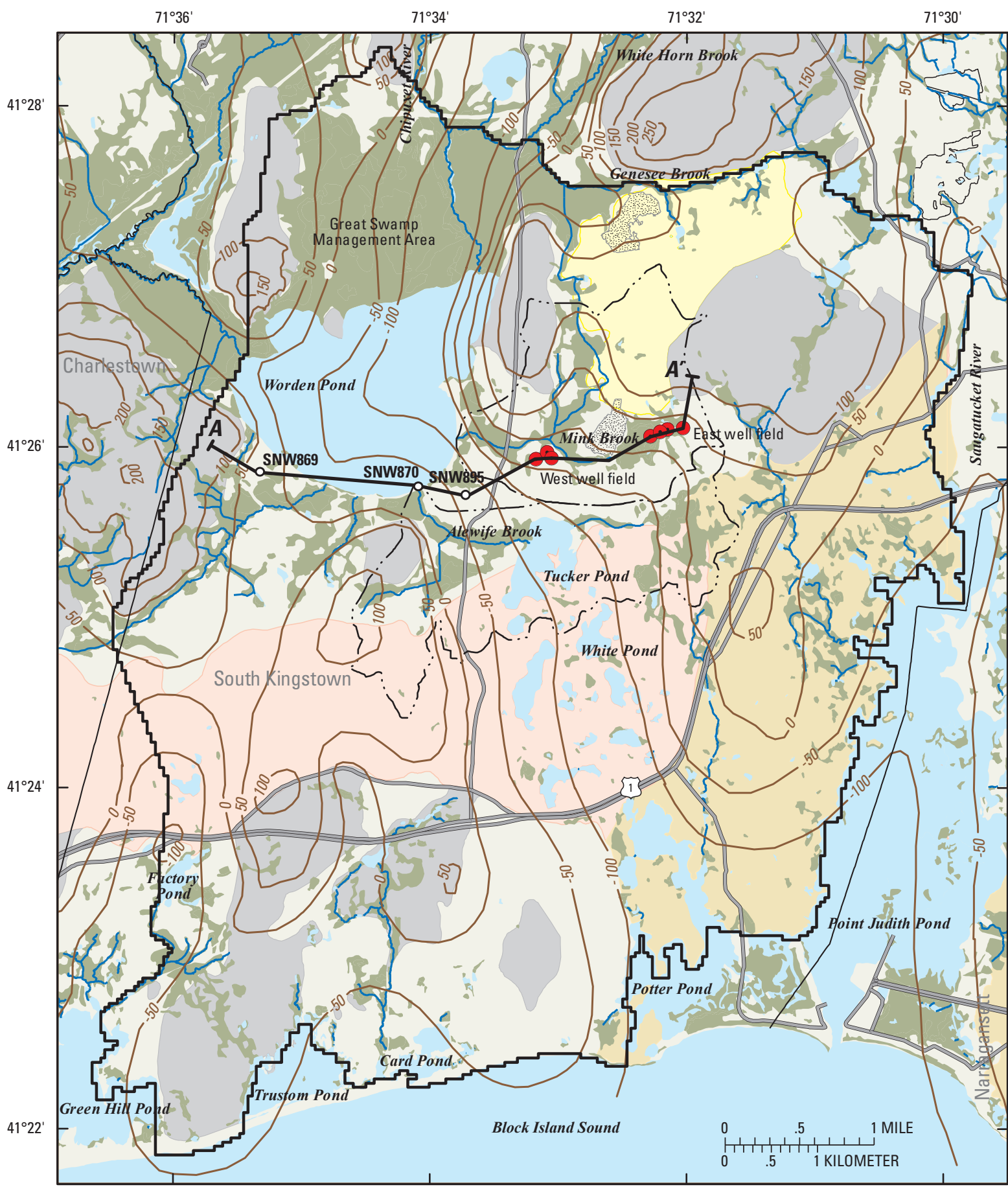

Base from U.S. Geological Survey,
Rhode Island state plane projection, 1:24,000, NAD 83

\begin{tabular}{|l|}
\hline Charlestown moraine \\
\hline Point Judith moraine \\
\hline Undifferentiated morainal deposit \\
\hline Stratified deposits \\
\hline Till and bedrock outcrops \\
\hline Wetlands \\
\hline Water (ponds, ocean) \\
\hline Sand and gravel operation \\
\hline
\end{tabular}

EXPLANATION

re Model boundary

.. Mink Brook and Alewife Brook watershed boundaries

- -50 - Bedrock-surface contours-Interval 50 feet

$A \quad A^{\prime}$ Line of geologic cross section

- Boring and identifier

- Production well

Figure 2. Production wells, section line, selected borings, model extent, bedrock-surface contours, and surficial geology, South Kingstown study site, southern Rhode Island. Bedrock-surface contours from Masterson and others (2007). 
Table 1. Characteristics of the production wells for the South Kingstown and Charlestown study sites, southern Rhode Island.

[Altitudes in feet relative to NGVD 29. USGS, U.S. Geological Survey; ft, foot; in., inch; gal/min, gallons per minute; UWRI, United Water Rhode Island; CBFD, Central Beach Fire District; EBWA, East Beach Water Association; --, unknown]

\begin{tabular}{|c|c|c|c|c|c|c|c|c|c|c|}
\hline \multicolumn{2}{|c|}{ Name } & \multirow{2}{*}{$\begin{array}{l}\text { Water } \\
\text { supplier }\end{array}$} & \multicolumn{2}{|c|}{ Year } & \multirow{2}{*}{$\begin{array}{c}\text { Altitude } \\
\text { of land } \\
\text { surface } \\
\quad \text { (ft) }\end{array}$} & \multirow{2}{*}{$\begin{array}{c}\text { Screen } \\
\text { diameter } \\
\text { (in.) }\end{array}$} & \multirow{2}{*}{$\begin{array}{c}\text { Depth of } \\
\text { screen top and } \\
\text { bottom below } \\
\text { land surface } \\
\text { (ft) }\end{array}$} & \multirow{2}{*}{$\begin{array}{l}\text { Screen } \\
\text { altitude top } \\
\text { and bottom } \\
\text { (ft) }\end{array}$} & \multirow{2}{*}{$\begin{array}{l}{ }^{1} \text { Average } \\
\text { pumping } \\
\text { rate } \\
\text { (gal } / \mathrm{min} \text { ) }\end{array}$} & \multirow{2}{*}{$\begin{array}{c}{ }^{2} \text { Maximum } \\
\text { pumping } \\
\text { rate } \\
\text { (gal } / \mathrm{min} \text { ) }\end{array}$} \\
\hline USGS & Local & & Drilled & Inservice & & & & & & \\
\hline \multicolumn{11}{|c|}{ South Kingstown } \\
\hline SNW81 & PW1 & UWRI & 1942 & 1944 & 106 & 12 & 45 to 75 & 61 to 31 & 51 & 400 \\
\hline SNW84 & PW2 & UWRI & 1945 & 1946 & 99 & 12 & 33.6 to 55 & 65.4 to 44 & 223 & 550 \\
\hline SNW91 & PW3 & UWRI & 1949 & 1949 & 95 & 12 & 34 to 54 & 61 to 41 & 45 & 400 \\
\hline SNW887 & PW4 & UWRI & 1958 & 1958 & 103 & 18 & 36 to 51 & 67 to 52 & 339 & 1,350 \\
\hline \multicolumn{3}{|c|}{ Total east well field } & & & & & & & 658 & 2,700 \\
\hline SNW1063 & PW5 & UWRI & 1966 & 1966 & 101.9 & 18 & 78.5 to 98.5 & 23.4 to 3.4 & 670 & 1,000 \\
\hline SNW1156 & PW6 & UWRI & 1971 & 1972 & 101.8 & 18 & 53.5 to 84 & 48.3 to 17.8 & 810 & 1,300 \\
\hline SNW1226 & PW7 & UWRI & 2001 & 2006 & 113.9 & 18 & 80 to 105 & 33.9 to 8.9 & 0 & 1,100 \\
\hline \multicolumn{3}{|c|}{ Total west well field } & & & & & & & 1,480 & 32,400 \\
\hline \multicolumn{5}{|c|}{ Total UWRI well fields } & & & & & 2,138 & 5,100 \\
\hline \multicolumn{11}{|c|}{ Charlestown } \\
\hline CHW36 & PW1 & CBFD & 1946 & -- & 10 & 8 & 18 to 28 & -8 to -18 & 5 & 50 \\
\hline CHW580 & PW2 & CBFD & 1965 & -- & 10 & 8 & 12.5 to 21.5 & -2.5 to -11.5 & 5 & 50 \\
\hline Total & & & & & & & & & 10 & 100 \\
\hline CHW591 & PW1 & EBWA & 1953 & 1953 & 10 & 8 & 17.5 to 27 & -7.5 to -17 & 3 & 100 \\
\hline CHW592 & PW2 & EBWA & 1965 & 1965 & 10 & 8 & 18.5 to 28 & -8.5 to -18 & 3 & 30 \\
\hline Total & & & & & & & & & 6 & 130 \\
\hline Total & BFD ar & EBWA & & & & & & & 16 & 230 \\
\hline
\end{tabular}

${ }^{1}$ Average pumping rate for years 2003-2007.

${ }^{2}$ Maximum-rated capacity of pump.

${ }^{3}$ Sum of two largest maximum pumping rates.

at five sites in the Mink Brook watershed and at five sites in adjacent watersheds. Peat thickness profiles were measured with a hand-held steel rod at each well field, and lithologic logs from USGS reports and from those of other organizations were compiled to define grain size of the stratified deposits and of post-glacial deposits.

\section{Geology}

In the South Kingstown study area, glacial and postglacial deposits overlie igneous and metamorphic bedrock of predominately granitic composition (Moore, 1964). Bedrock valleys generally trend north-south (Masterson and others, 2007) (fig. 2). The axis of a main preglacial river valley trends southward beneath Great Swamp and Worden Pond, continues southeastward near the west well field, and then passes beneath Charlestown Moraine and Point Judith Moraine into Block Island Sound. Surficial deposits thicker than $250 \mathrm{ft}$ fill this preglacial valley near the kettle ponds in the Charlestown Moraine. Thickness of surficial deposits ranges from more than $120 \mathrm{ft}$ at the west well field to about $80 \mathrm{ft}$ at the east well field.

Glacial sediments consist of stratified deposits, till, and morainal deposits (fig. 2). Glacial stratified deposits south of the Charlestown Moraine were deposited by glacial meltwater in broad flood plains away from the ice, whereas stratified deposits were laid down near the ice (ice-contact deposits) north of the moraine within the study area (Kaye, 1960). Till covers the bedrock surface in most places and is about $20 \mathrm{ft}$ thick in upland areas and generally more than $10 \mathrm{ft}$ thick in lowlands beneath stratified deposits. Numerous bedrock outcrops are present on the isolated upland hills directly northwest and southwest of Worden Pond. The Charlestown 


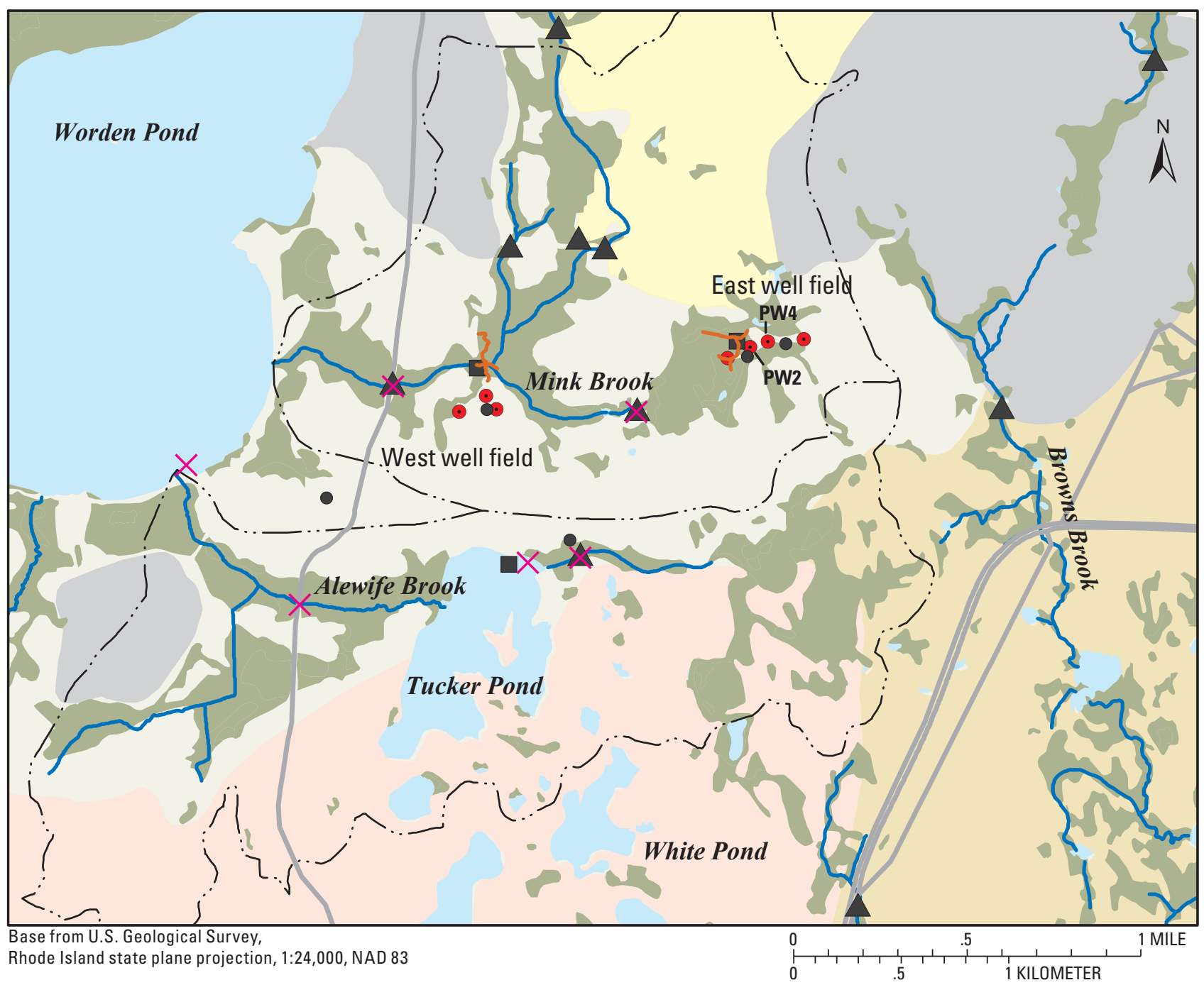

EXPLANATION
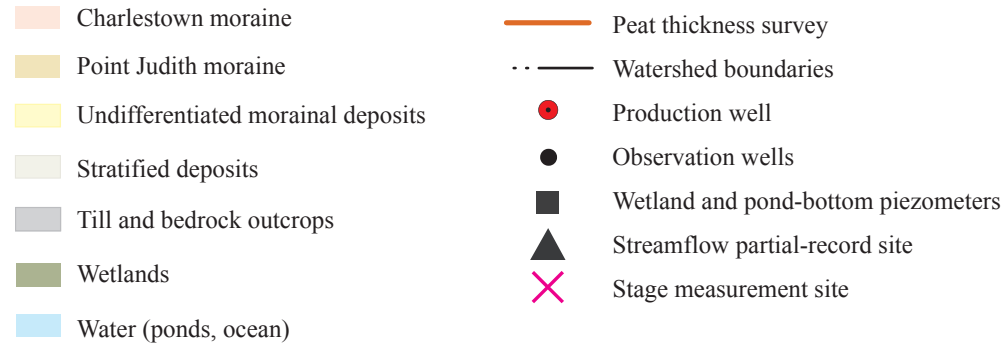

Figure 3. Data-collection network near production wells, South Kingstown study site, southern Rhode Island. 
Moraine and the Point Judith Moraine represent long-term recessional positions of the retreating glacier; they consist of interstratified till and sorted deposits (Kaye, 1960).

Glacial meltwater deposited the stratified sediments in morphosequences during temporary standstills of the last retreating glacial ice sheet (Stone and others, 2005; Masterson and others, 2007). Sediment size generally decreases and sorting increases with distance from the ice margin. The vertical distribution and thickness of surficial deposits along a generalized west-east geologic section through the production well fields are shown in figure 4 . The geologic section shows a profile through a depositional sequence trending northeastsouthwest. Glacial stratified deposits were grouped into three units on the basis of the dominant grain sizes: sand and gravel; sand; and fine-grained sediment composed of very fine sand, silt, and clay. All seven production wells are screened in sand and gravel deposits at medium depth or near the bottom of this coarse-grained unit. A limited number of lithologic logs collected by Allen and others (1963) and Boothroyd and others (1998) were available from beneath Great Swamp and Worden Pond. These logs indicated a younger morphosequence north of the sequence shown in figure 4 trending north-south with sands covering lacustrine deposits of Glacial Lake Worden. These lacustrine deposits represent the majority of the known fine-grained sediments in the study area.

Post-glacial wetland deposits consist of peat in various stages of decomposition. Manual probing of the peat near both well fields (fig. 3 ) indicated that the thickness of the peat and organic-rich sediment ranged from less than $1 \mathrm{ft}$ near the edge of the wetlands to greater than $11 \mathrm{ft}$ in the center of the wetlands near the east well field; peat thickness generally ranged from 5 to $8 \mathrm{ft}$ near the well fields. Peat deposits also extend beneath Worden Pond (fig. 4). Core samples of the pond bottom that Boothroyd and others (1998) collected indicated an average thickness of about $3 \mathrm{ft}$ for the peat and organic-rich sediment.

\section{Hydrology}

The study area includes parts of two large watersheds in southern Rhode Island - the Chipuxet River and the South Coastal watersheds (figs. 1 and 2). The Charlestown Moraine, deposited across the pre-glacial river valleys, forms a ridge of as much as $150 \mathrm{ft}$ above the land surface surrounding Worden Pond, and it forms most of the surface-water divide between these two watersheds in the southern part of the Chipuxet River watershed. According to Tiner (1989), the Charlestown Moraine promoted wetland formation by blocking surface drainage from the north; these wetlands are generally densely vegetated and are considered palustrine forested and scrubshrub wetlands. The Chipuxet River flows southward through Great Swamp and into Worden Pond; west of Worden Pond, the Chipuxet River becomes the Pawcatuck River.

The water-table map drawn by Bierschenk (1956) indicated a groundwater divide between the Chipuxet River and Block Island Sound located in the Charlestown Moraine. Because of minimal water-level data in the moraine, however, the location of the groundwater divide in the moraine and its proximity to the surface-water divide is unknown. Kettlepond altitudes listed on the USGS Kingston quadrangle along the axis of the main pre-glacial valley indicate that the groundwater divide is most likely between Tucker Pond and White Pond in this area of the moraine. The manually calibrated regional model (Masterson and others, 2007) simulated a groundwater divide between the Chipuxet and South Coastal watersheds that is mostly within the moraine.

The production well fields are in a small subbasin of the Chipuxet River, Mink Brook, which drains $1.82 \mathrm{mi}^{2}$ at its confluence with Worden Pond (fig. 2). The production wells are screened in transmissive sand and gravel deposits adjacent to Mink Brook and wetlands. The vertical placements of the production well screens in relation to Worden Pond and to nearby wetlands are shown in figure 4 . Transmissivity values ranging from 8,000 to $21,000 \mathrm{ft}^{2} / \mathrm{d}$ were calculated for the sand and gravel deposits from short-duration (24 hrs) aquifer tests at the east well field (Allen and others, 1966); the associated hydraulic conductivities ranged from 100 to $400 \mathrm{ft} / \mathrm{d}$, and the median value was $150 \mathrm{ft} / \mathrm{d}$.

The source of all water in the study area is precipitation. Mean annual streamflow (precipitation minus evapotranspiration) from long-term streamgages in southern Rhode Island provides an estimate of water available for recharge (see section "Recharge Rates"). Even though surface-water and groundwater divides may not coincide in transmissive materials, estimates of water available for recharge in watersheds when compared to pumping rates provide insights into the hydrology. A recharge rate of $29 \mathrm{in} / \mathrm{yr}$ over the Mink Brook watershed $\left(1.82 \mathrm{mi}^{2}\right)$ is equivalent to $3.9 \mathrm{ft}^{3} / \mathrm{s}$ or $1,750 \mathrm{gal} / \mathrm{min}$. The total average well field withdrawal rate of $2,138 \mathrm{gal} / \mathrm{min}$ and the total maximum well field withdrawal rate of 5,100 gal/min exceed the water potentially available in this small watershed; therefore, for the steady-state model simulations, the well fields must derive part of their pumped water from outside Mink Brook watershed. If Alewife Brook watershed $\left(2.08 \mathrm{mi}^{2}\right)$, which shares a nearby common boundary in transmissive stratified deposits with Mink Brook watershed, is included in the calculation, the total water available is $8.3 \mathrm{ft}^{3} / \mathrm{s}$ or $3,730 \mathrm{gal} / \mathrm{min}$. The total average well field withdrawal rate is about 60 percent of the water available for these two watersheds. To sustain withdrawals at the maximum pumping rate scenario, sources of water outside of these two watersheds must be withdrawn from the well fields.

Streams, wetlands, and ponds are potential sources of water to the well fields through natural infiltration, induced infiltration caused by pumping, or both. Streamflow measurements at five partial-record sites and water levels at two wetland-piezometer sites provide insights into surfacewater and groundwater interactions in the Mink Brook watershed (fig. 3). 


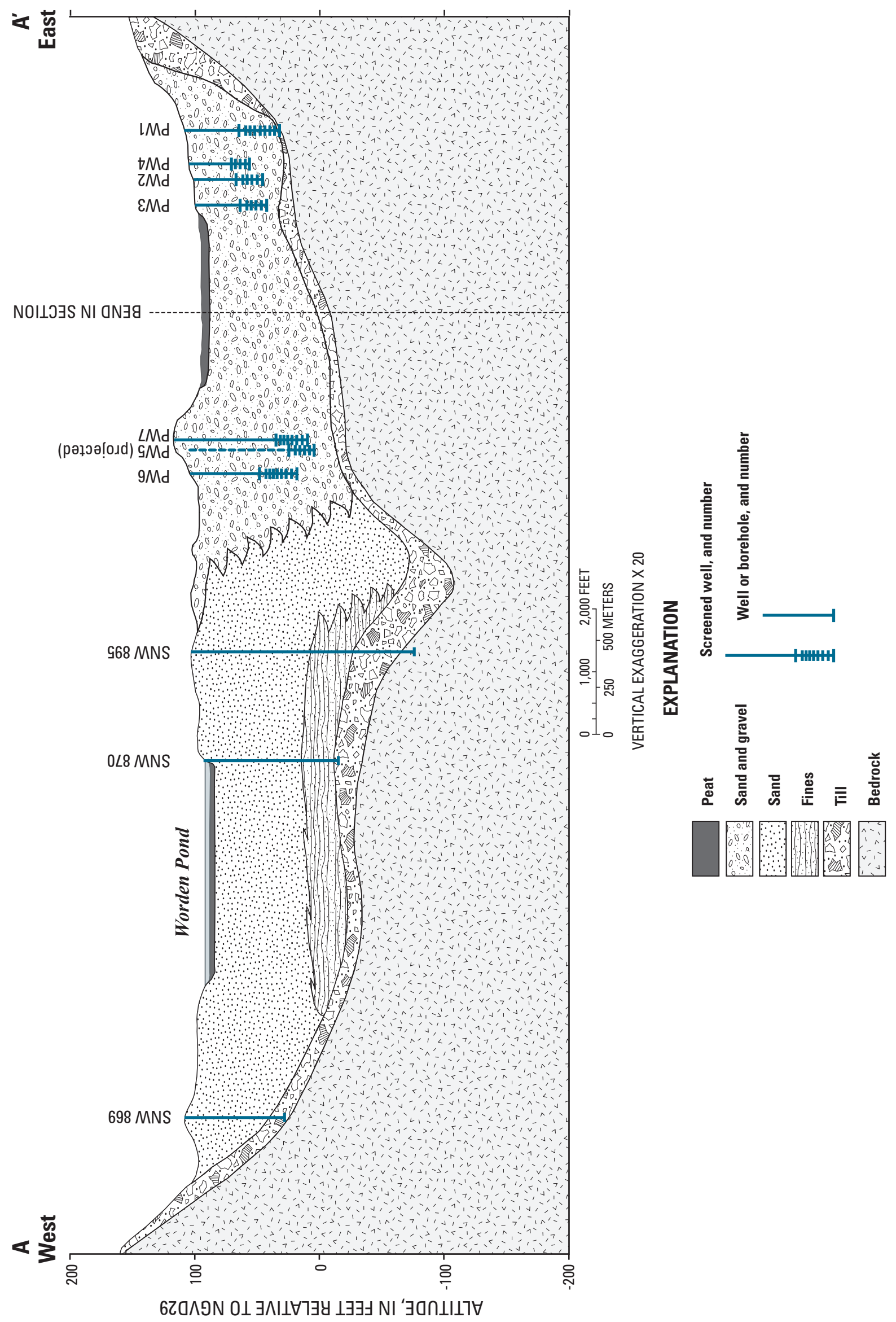


A set of instantaneous streamflow measurements was made on June 15, 2007, near mean annual streamflow and groundwater-level conditions (figs. 5 and 6). Small southwardflowing tributaries to Mink Brook drain a hillslope before entering the valley, which is underlain by thick wetland deposits. Limited field observations in this densely vegetated part of the wetland indicated small, separate pools of surface water but no visible channels entering Mink Brook from the north, in contrast to the stream network delineated at the 1:5,000 scale. Flow in three streams near the base of this hillslope ranged from 0.01 to $0.03 \mathrm{ft}^{3} / \mathrm{s}$, totaling $0.05 \mathrm{ft}^{3} / \mathrm{s}$ or $22 \mathrm{gal} / \mathrm{min}$. This streamflow most likely infiltrates the groundwater system in the valley because shallow peat generally consists of recent, slightly decomposed permeable deposits. Streamflow measurements made at culverts in the main stem of Mink Brook between the well fields and downstream of the west well field indicated a slight net loss of $0.04 \mathrm{ft}^{3} / \mathrm{s}$ (18 gal $\left./ \mathrm{min}\right)$, which was within the accuracy of the measurements. Infiltration, evapotranspiration, measurement error, or any combination of these may cause this loss.

Groundwater and surface-water levels were measured at a vertical nest of piezometers installed in the peat and in the underlying stratified deposits in the vicinity of each well field. Peat and organic-rich sediment are $6 \mathrm{ft}$ thick at each wetland-piezometer site. A small-diameter piezometer with 0.5 -ft-length screen was installed near the middle of the peat, and a piezometer with a 3-ft-length screen was installed 3 to $6 \mathrm{ft}$ beneath the peat in the sand and gravel deposits at each site. The wetland-piezometer site near the west well field was installed in the channel of Mink Brook $500 \mathrm{ft}$ from PW5, whereas the wetland-piezometer site near the east well field was installed in a wetland with no defined channel $200 \mathrm{ft}$ from PW2. Water levels were measured periodically from November 2006 to October 2008, most of them between April 2007 and October 2008, either manually or by a recorder at 30-minute intervals (fig. 7). The production wells were operated on a varied pumping schedule. Well-field withdrawals were highest during the summer months, a period of generally minimal recharge from precipitation.

Water levels and field observations indicated that surface water in Mink Brook and in wetlands was intermittent under the climatic and pumping conditions during 2006-2008. Groundwater levels and streamflows in southern Rhode Island were below monthly normals (in the lowest 25 percentile of long-term monthly data) during August 2007 to January 2008 (U.S. Geological Survey, 2008). Mink Brook ceased to flow and wetlands ceased to be covered with water beginning in midsummer; for 2007 and 2008, the cessation continued into the fall, and for 2008, persisted most of the winter. As water levels continued to drop, the peat became dry by late summer. Annual water-level fluctuations in the sand and gravel deposits were about $10 \mathrm{ft}$, which compared with variations of 5 to $6 \mathrm{ft}$ at USGS long-term observation wells (CHW18 and SNW6; fig. 1) that are not influenced by pumping. A comparison of surface-water and groundwater levels indicates a generally downward vertical gradient and the potential for surface water in the wetlands and groundwater in the peat to infiltrate the underlying aquifer. Water levels at the wetland-piezometer site near the west well field indicated a downward gradient except for the April 2007 measurement, which was made after two days of no pumping at the west well field. Groundwater levels in the sand and gravel at this site showed minimal response to cycles of on-and-off pumping because of the distance between the piezometer site and the production wells. Because the wetland-piezometer site near the east well field is closer to pumping wells, groundwater levels in the sand and gravel respond to the cyclical nature of the well-field operation, including reversals of the vertical gradient.

Water levels at the wetland-piezometer site near the east well field during a period of prolonged pumping (March 14-April 3, 2008) (figs. 7B and 8) were analyzed to determine hydraulic properties at the well-field site, specifically the vertical hydraulic conductivity of peat, which controls vertical flow between the wetlands and the aquifer. PW2 and PW4 were pumped at a combined rate of 1,350 $\mathrm{gal} / \mathrm{min}$ for 90 percent of this 20-day, 3-hour period; the average withdrawal rate during this period was equivalent to $1,220 \mathrm{gal} / \mathrm{min}$. This prolonged pumping period was preceded by 24 hours of no pumping, during which water levels returned to an upward gradient before pumping commenced again.

Water-level drawdown in the sand and gravel piezometer was analyzed by means of an analytical method described by Hantush and Jacob (1955) and by Hantush (1956) for leaky aquifers. The analytical method includes several simplifying assumptions, such as horizontal flow in the sand and gravel aquifer, vertical flow through the semi-confining layer (peat), constant water level in the layer supplying leakage (surface water in the wetlands), and homogenous hydraulic properties in individual layers (sand and gravel, peat, and surface water). This method also assumes no release of water from storage in the peat. Water-level trends were assumed negligible during the aquifer test. This assumption was supported by a leveling of trends in the peat piezometer before and during the aquifer test and general trends in the sand and gravel parallel trends in the peat (fig. 7B). Because of these simplifying assumptions and because pumping was not continuous, the analytical solution provides only a rough estimate of hydraulic properties.

Curve matching showed that the shape of the drawdown curve from the sand and gravel deviated from the Theis (1935) type curve, thereby indicating vertical leakage from the wetlands (fig. 8). Transmissivity of the sand and gravel and vertical hydraulic conductivity of the peat were calculated from the drawdown curve and a leaky aquifer type curve (fig. 8). A calculated transmissivity value of $18,900 \mathrm{ft}^{2} / \mathrm{d}$ is within the range of transmissivity values that Allen and others (1966) determined at the well field. The vertical hydraulic conductivity of peat, which uses the transmissivity value in its estimate, was calculated as $0.01 \mathrm{ft} / \mathrm{d}$. This vertical hydraulic conductivity value determined from the drawdown data was comparable to a hydraulic conductivity value of $0.3 \mathrm{ft} / \mathrm{d}$ for 


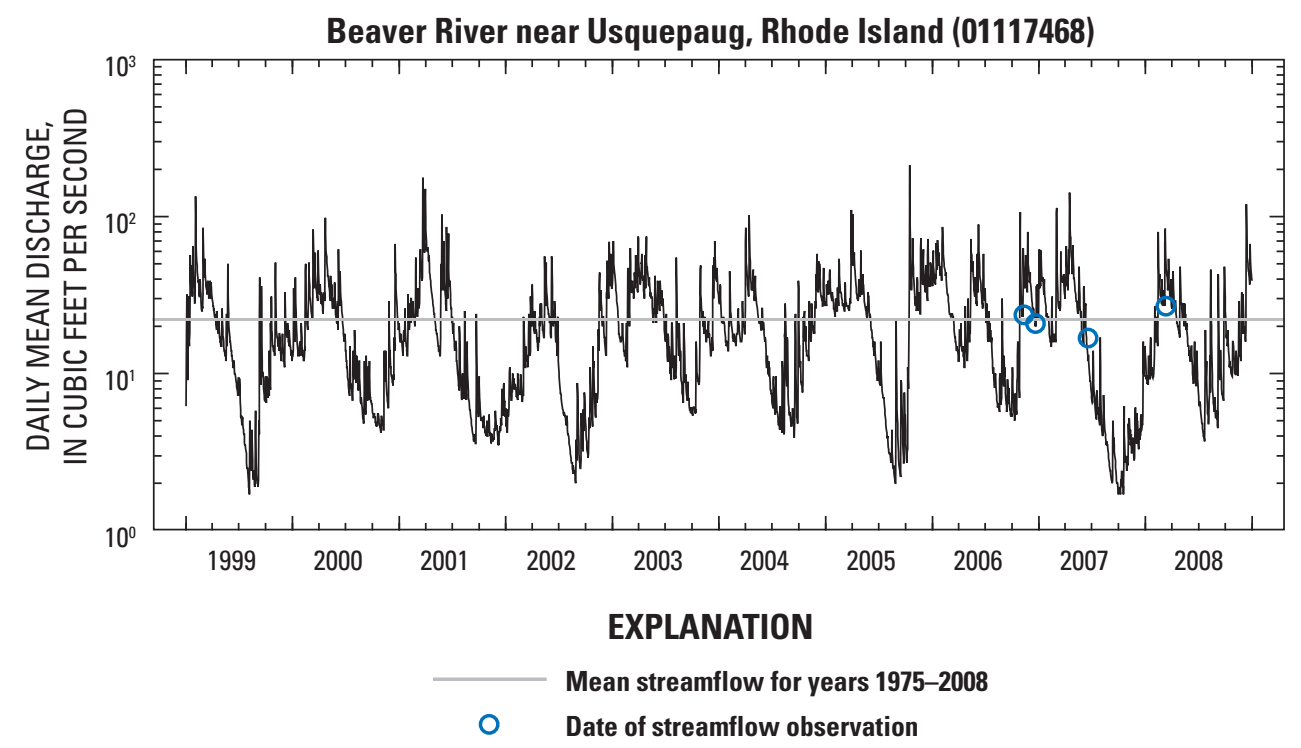

Figure 5. Streamflow for the Beaver River streamgage (01117468) near Usquepaug, Rhode Island, during 1999-2008 (streamgage location shown on figure 1).

the peat, which had been determined from a relation between hydraulic conductivity and 20 samples tested for bulk density in southwest Rhode Island (Friesz, 2004).

Worden Pond is also a potential source of water to the well fields, especially in the maximum pumping rate scenario. Worden Pond is a shallow (mean depth $4 \mathrm{ft}$; Guthrie and Stolgitis, 1977) but large (surface area $1.7 \mathrm{mi}^{2}$ ) pond. Chipuxet River enters the pond in the northeast and the river outlet is in the west; numerous small streams flow into the pond in the south and east. At the Chipuxet River streamgage, $2.3 \mathrm{mi}$. north of Worden Pond, mean annual streamflow is $21.8 \mathrm{ft}^{3} / \mathrm{s}$ (U.S. Geological Survey, 2007). On the basis of streamflow characteristics at this streamgage, mean annual streamflow of the Chipuxet River at its confluence with White Horn Brook a mile north of Worden Pond is estimated to be $34 \mathrm{ft}^{3} / \mathrm{s}$. This flow rate, which does not include all water that enters Worden Pond, is three times the combined maximum pumping rate for the two well fields, 5,100 gal $/ \mathrm{min}$ or $11.4 \mathrm{ft}^{3} / \mathrm{s}$.

\section{Simulation of Groundwater Flow and Areas Contributing Recharge}

The groundwater-flow model for the South Kingstown study site was designed to simulate long-term, steady-state groundwater levels, flow paths, and traveltimes. The model was calibrated to 2003-07 average annual pumping conditions based on historical observations and on observations made during this study. Deterministic areas contributing recharge to the well fields for different pumping-rate scenarios are based on the optimal set of parameters. An uncertainty analysis provided insights into the effects of the uncertainty in these estimated parameter values on the delineated contributing area to the well fields. Wastewater return flow through private septic systems was not simulated in the model. Simulated contributing areas to the well fields, however, are mostly in the rural, residential area of the Chipuxet River watershed where total return flow is minimal. The areas contributing recharge to the well fields, therefore, represent slightly larger, more conservative areas than if return flow had been included in the model.

\section{Model Extent and Spatial Discretization}

Groundwater flow in the surficial deposits and the underlying bedrock was simulated by a five-layer numerical model with a uniformly spaced finite-difference grid. The model extended to natural hydrologic boundaries beyond the likely area contributing recharge to the well fields. This extent also allowed the location of the simulated groundwater divides near the well fields to shift, depending on the hydraulic properties, recharge rates, and pumping rates used in the model. The lateral model boundaries included streams in the north and northeast (Chipuxet River and its tributaries Genesee and White Horn Brooks, Saugatucket River, and an unnamed tributary), Block Island Sound and numerous coastal ponds in the southeast and south (Point Judith, Potter, Card, Trustom, and Green Hill Ponds), and in the west, presumed groundwater divides in the till uplands and small areas of stratified deposits and a segment drawn from Factory Pond northward where groundwater flow is assumed to be parallel. The active model represented an area of $29.2 \mathrm{mi}^{2}$, consisted of 263 rows and 209 columns, and included a total of 180,710 cells with each $150 \mathrm{ft}$ on a side. 

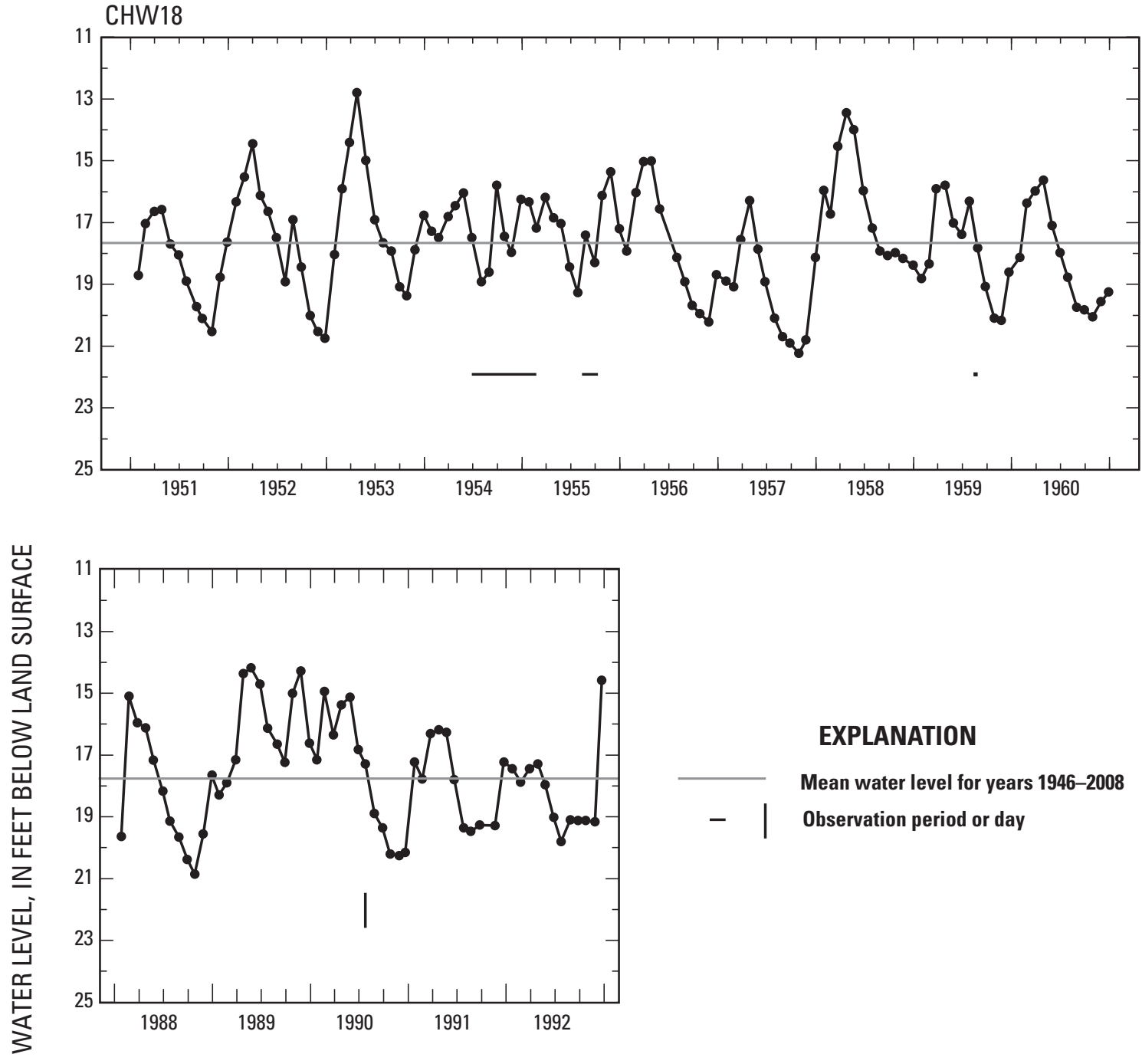

\section{EXPLANATION}

Mean water level for years 1946-2008

Observation period or day

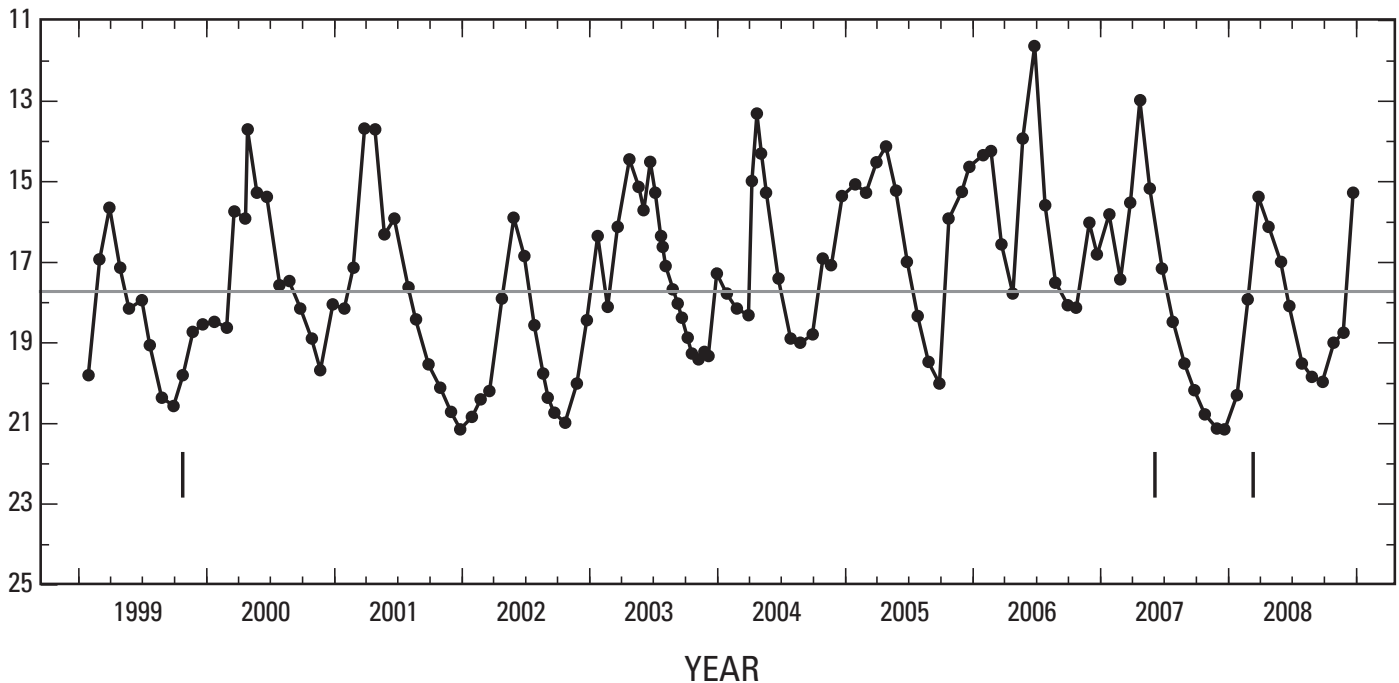

Figure 6. Water levels measured in observation well CHW18 during 1951-60, 1988-92, and 1999-2008, Charlestown, Rhode Island (well location shown in figure 1). 


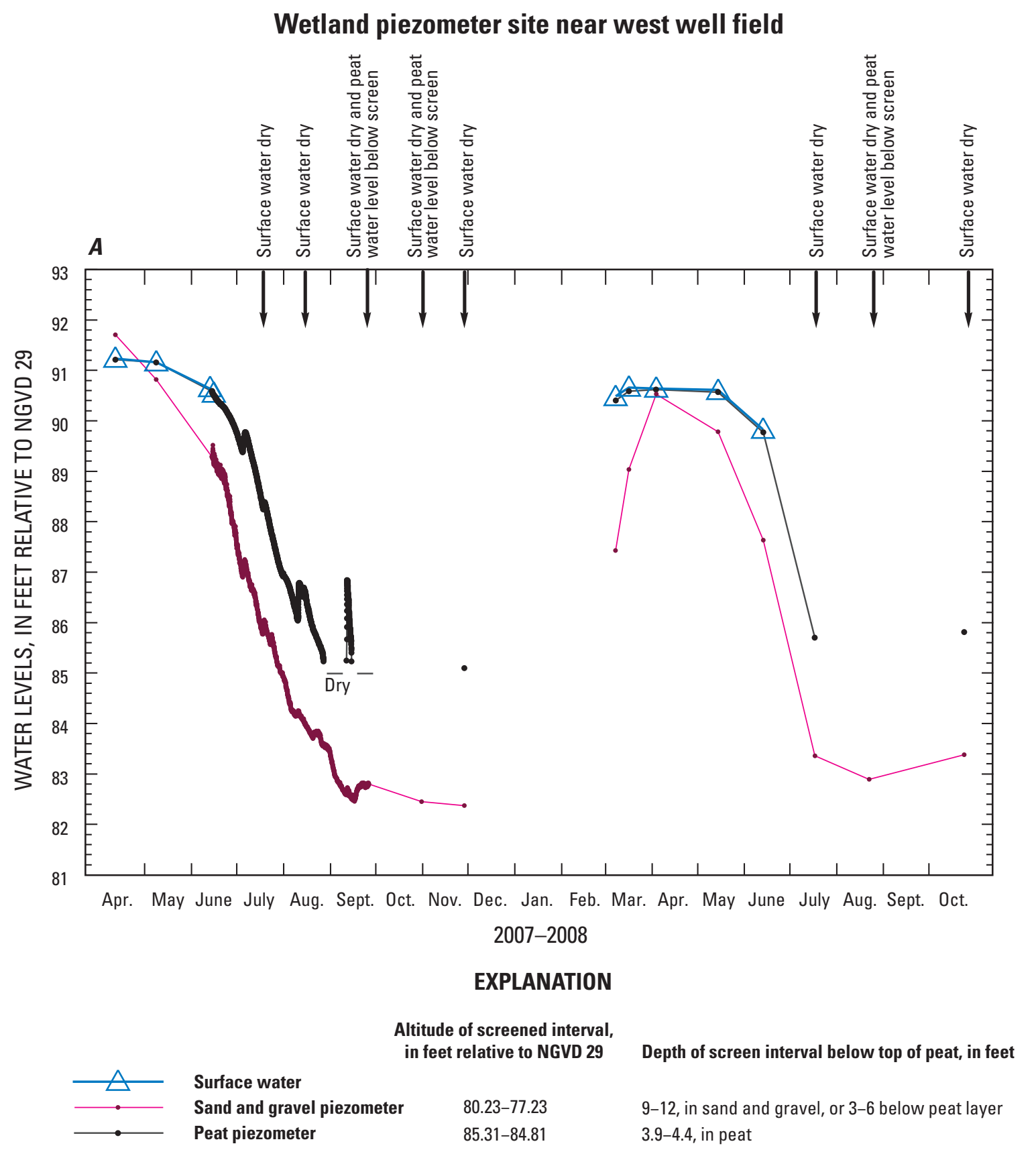

Figure 7. Stage of wetland and water levels in piezometers screened in peat, and in sand and gravel near $A$, west well field and B, east well field, 2007-2008, South Kingstown study site, southern Rhode Island. 


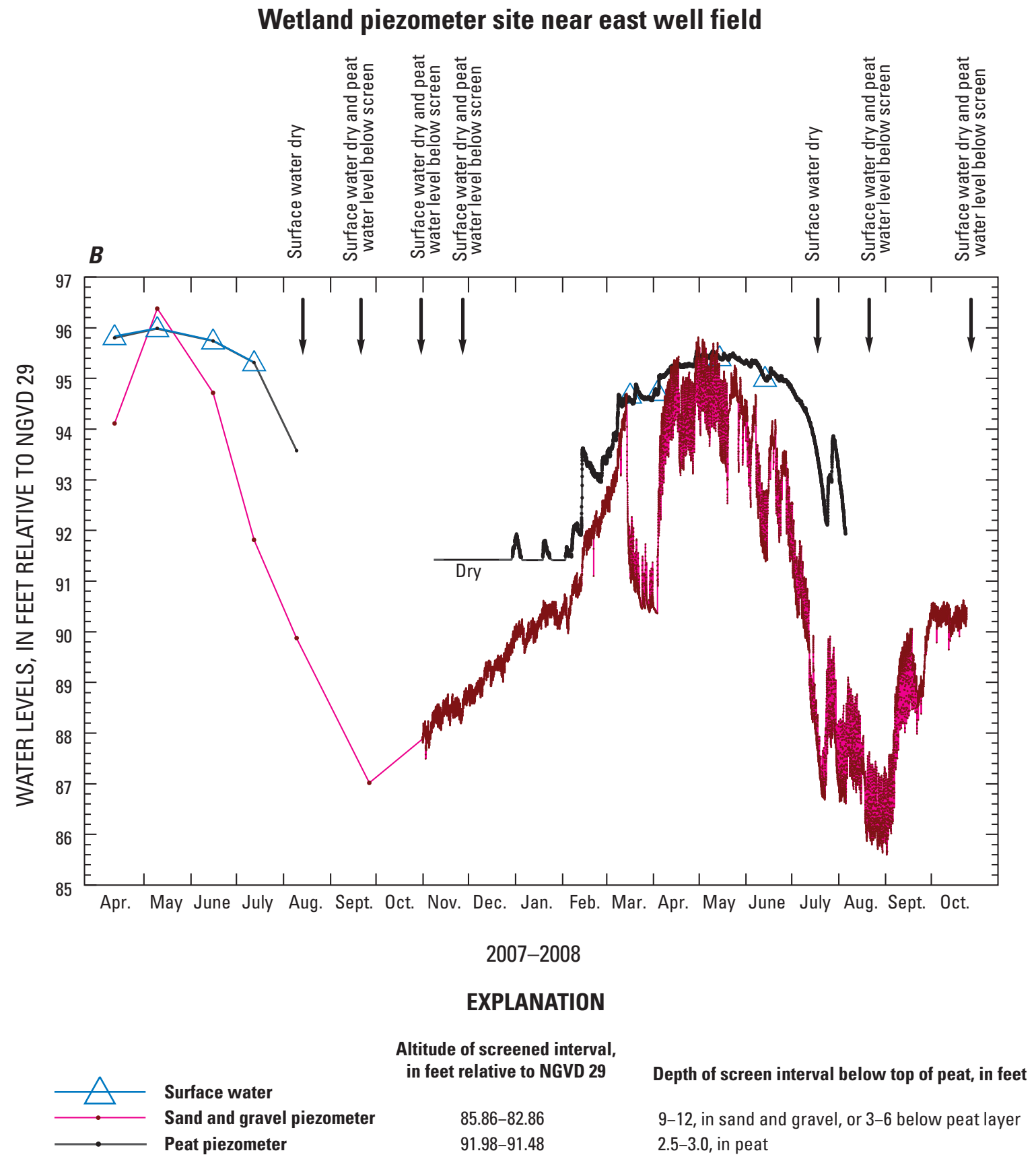

Figure 7. Stage of wetland and water levels in piezometers screened in peat, and in sand and gravel near $A$, west well field and $B$, east well field, 2007-2008, South Kingstown study site, southern Rhode Island.—Continued 


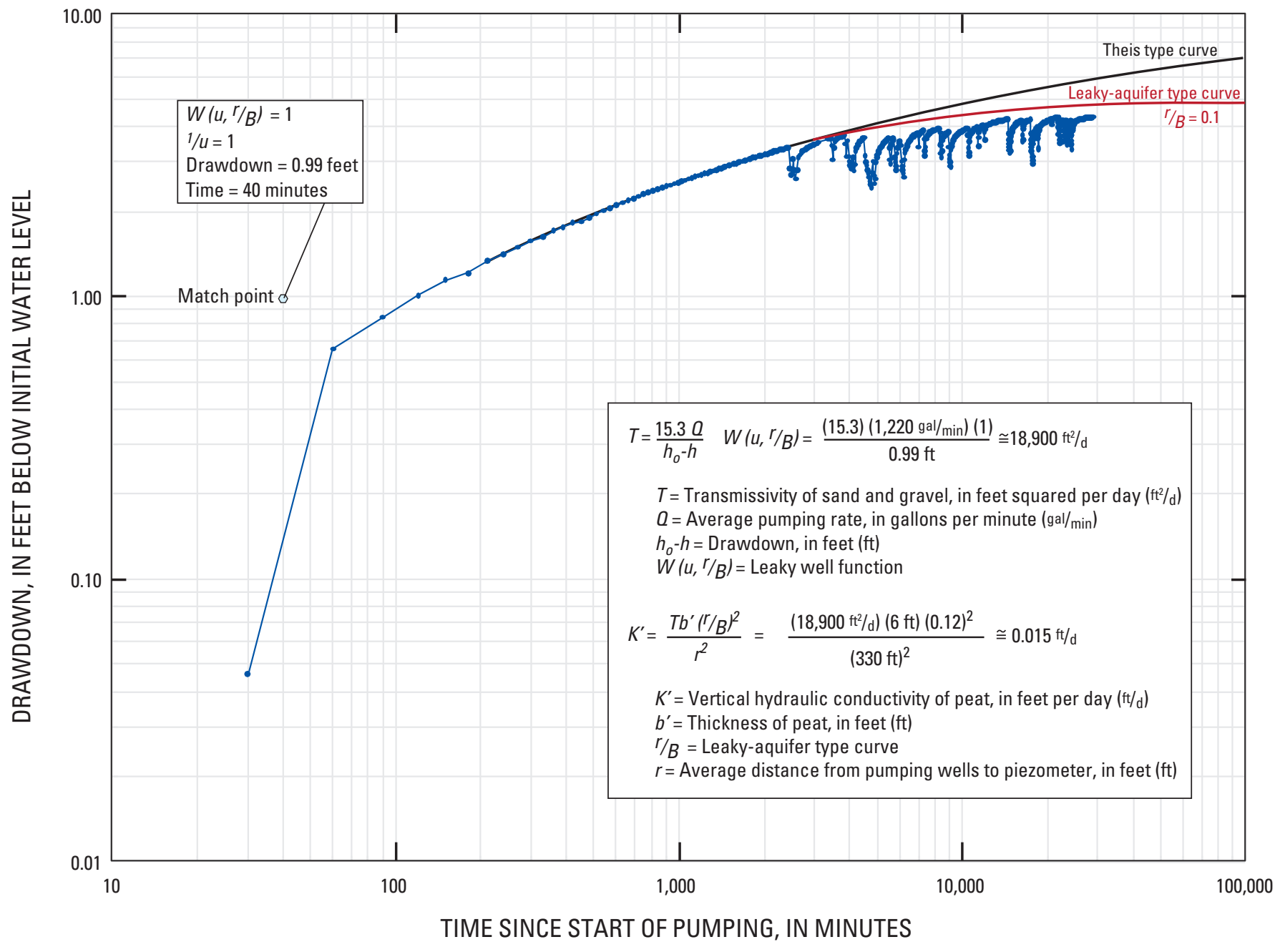

\section{EXPLANATION}

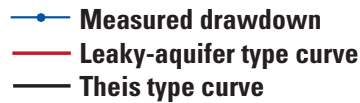

Figure 8. Plot of drawdown with time compared to a Theis type curve and a leaky-aquifer type curve for a piezometer screened beneath the wetland near the east well field, March14-April 3, 2008, South Kingstown study site, southern Rhode Island. 
Model layers were simulated by using a fixed transmissivity, including layer 1, the top layer. The model was first set up by representing surficial deposits in one layer (the top layer) and bedrock in a second layer (the bottom layer). The unevenness of the bedrock surface (fig. 2) resulted in surficial deposits of variable thickness. The top of the model grid, which is used to determine transmissivity of the top layer, was initially set at land-surface altitude. The top of the model grid was reset by running the basic model, temporarily adjusting hydraulic properties until the simulated water table compared favorably to available water levels and land-surface altitudes, and then the simulated water-table altitude was used as the top of the model in subsequent simulations. The top layer was then subdivided into four layers (layers 1 to 4) based on surface-water features, lithology, and placements of the production well screens. Layer 1 is generally $2 \mathrm{ft}$ thick to represent surface water in the ponds and wetlands, and layer 2 is generally $5 \mathrm{ft}$ thick to represent peat deposits. Organic-rich pond-bottom sediments are $3 \mathrm{ft}$ thick for Worden Pond and $1 \mathrm{ft}$ thick for ponds elsewhere. Layers 3 and 4 represented 40 and 60 percent of the remaining deposits; the production wells are screened in layer 4. Stratified deposits, till, and the moraine are represented in all four layers. Shallow bedrock areas less than $8 \mathrm{ft}$ from the top of the model were incorporated into surrounding surficial materials. The bottom layer (now layer 5) represented bedrock with a constant thickness of $200 \mathrm{ft}$.

\section{Boundary Conditions and Model Parameters}

Several types of boundary conditions were specified in the model to represent areas of discharge and sources of recharge (fig. 9). Stream-aquifer interactions were simulated as head-dependent flux boundaries in layer 1 primarily by using the stream-routing package (Prudic, 1989) developed for MODFLOW. The stream-routing package accounts for gains and losses of water in each stream cell, and it routes streamflow from upstream cells to downstream cells. Streamflow loss to the aquifer, either naturally or from infiltration induced by pumping, would cease if simulated streamflow also ceases. Some streams that define the perimeter of the model were simulated by using the MODFLOW drain package, which only allows for a gain of water in the drain cell. Streams that flow into and out of ponds, except Worden Pond, were simulated as flowing through these water bodies. The model contained a total of 1,148 stream-routing cells and 243 drain cells. Surface-water altitudes for the head-dependent flux boundaries were determined from, or interpolated between, topographical contours intersecting streams and from pond altitudes listed on the USGS Kingston quadrangle. In addition, stage measurements made during this study on June 15, 2007, at seven stream and pond sites in Mink and Alewife Brooks and Worden and Tucker Ponds were used (fig. 3). Water depths and bed thicknesses of $1 \mathrm{ft}$ were used to determine the top and bottom bed altitudes from surface-water altitudes. Simulated streams were assigned 10 -ft widths and 150 - $\mathrm{ft}$ lengths, which is the model cell dimension.
Most streambed materials were assumed to consist of coarse-grained sediments. Field observations and manual probing with a steel rod indicated that bed materials in Mink Brook consisted of peat deposits; a vertical hydraulic conductivity of one-tenth the value of that of the other streams was therefore used. For this study, a dimensionless parameter (SB_MULT) was defined that multiplied the vertical hydraulic conductivity of the streams that the stream-routing package simulated. A dimensionless multiplier of 1 is equivalent to $1 \mathrm{ft} / \mathrm{d}$ for bed materials of sediment and $0.1 \mathrm{ft} / \mathrm{d}$ for bed materials of peat. A parameter value of 1 would also be equivalent to conductances of $1,500 \mathrm{ft}^{2} / \mathrm{d}$ and $150 \mathrm{ft}^{2} / \mathrm{d}$ for bed materials of sediment and peat, respectively. The final drain conductance was set equivalent to the stream-routing conductance calculated by parameter estimation.

A constant-head boundary was used to simulate large bodies of surface water such as Block Island Sound, coastal ponds that are connected to the Sound, and Worden Pond. The stage of Block Island Sound and the coastal ponds was assumed to be $0 \mathrm{ft}$ NGVD29, and the stage of Worden Pond was $90.3 \mathrm{ft}$ NGVD29 as measured June 15, 2007. Organicrich deposits beneath Worden Pond were simulated as a 3-ft-thick layer based on the average thickness determined from coring (Boothroyd and others, 1998). By using a constant head for Worden Pond and a 3-ft-thick layer to represent peat deposits beneath the pond, a single parameter could be used to represent peat throughout the model. The head-dependent river boundary with a 3 -ft bed thickness showed similar model results. The model contained 3,050 constant-head cells.

Recharge parameters were distributed based on surficial geology and on surface-water features (table 2). Recharge values used in the model are effective rates, which account for the effects of groundwater evapotranspiration. One recharge parameter represented both the stratified deposits and the morainal deposits (R_SDM); conceptually, recharge rates should be similar for both surficial materials because the morainal deposits consist of permeable materials. A second recharge parameter was defined for upland till (R_TILL). Any surface runoff from till hillslopes that may recharge permeable stratified and morainal deposits at the upland-valley contact was not included in model simulations. Hillslope runoff is most likely not a major component of recharge in the study site compared with other valley-fill settings because of the size of the valley in comparison to the size of the upland area. A recharge parameter was also defined for the wetlands (R_WETLD). Conceptually, this recharge parameter represents water available for recharge. Some or all of this water may infiltrate, particularly under pumping conditions, or it may move across the surface as overland flow. R_WETLD was therefore set at a fixed value for model calibration, but the uncertainty in the specified value was included in the probabilistic contributing area analysis. Pond recharge, which was specified for all model simulations, was important only for the small ponds because constant heads were used to simulate the large ponds. The same value of $22 \mathrm{in} / \mathrm{yr}$ was applied to pond water and to wetland areas by subtracting 


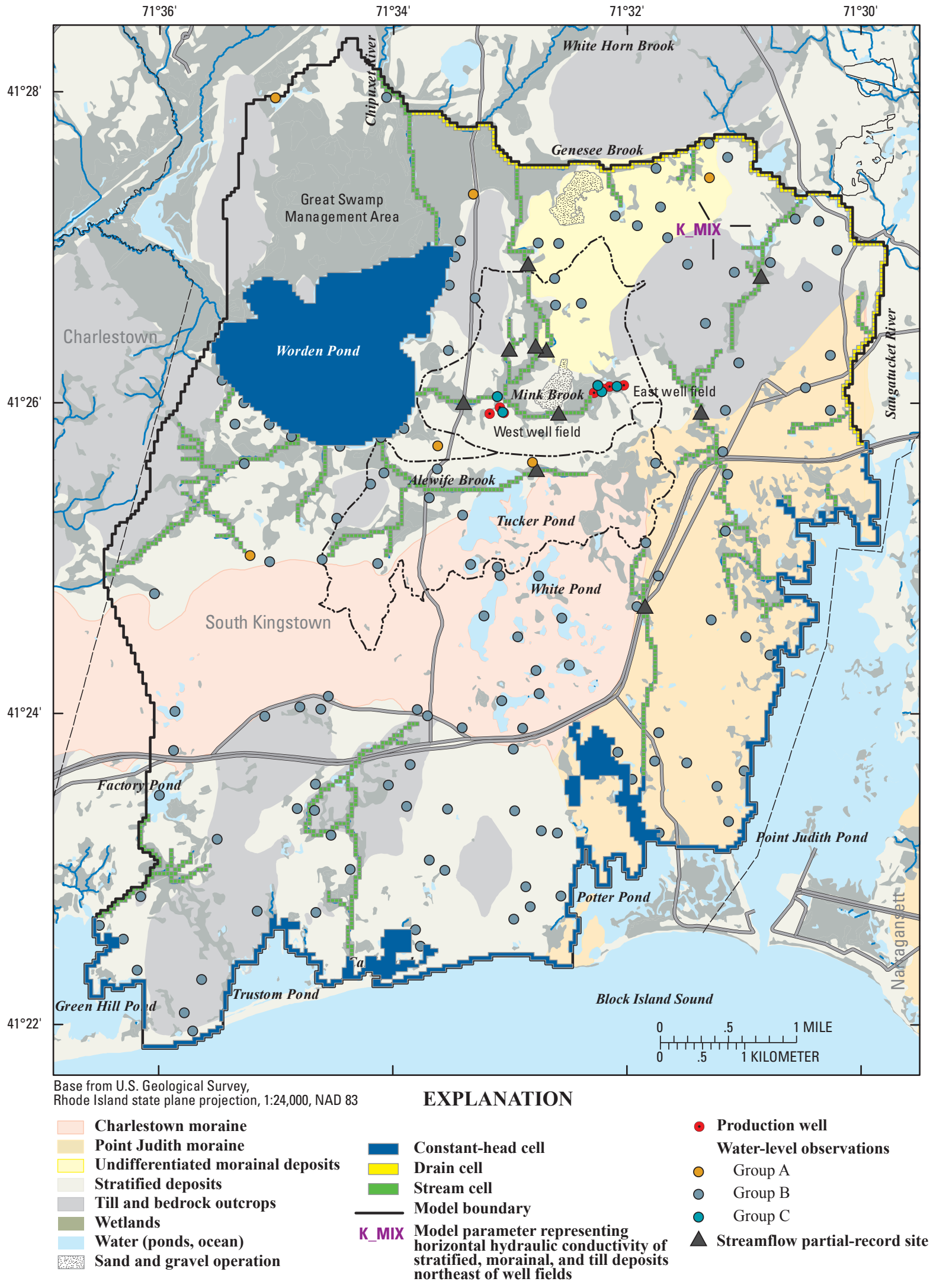

Figure 9. Model-boundary types and observations, South Kingstown study site, southern Rhode Island. 

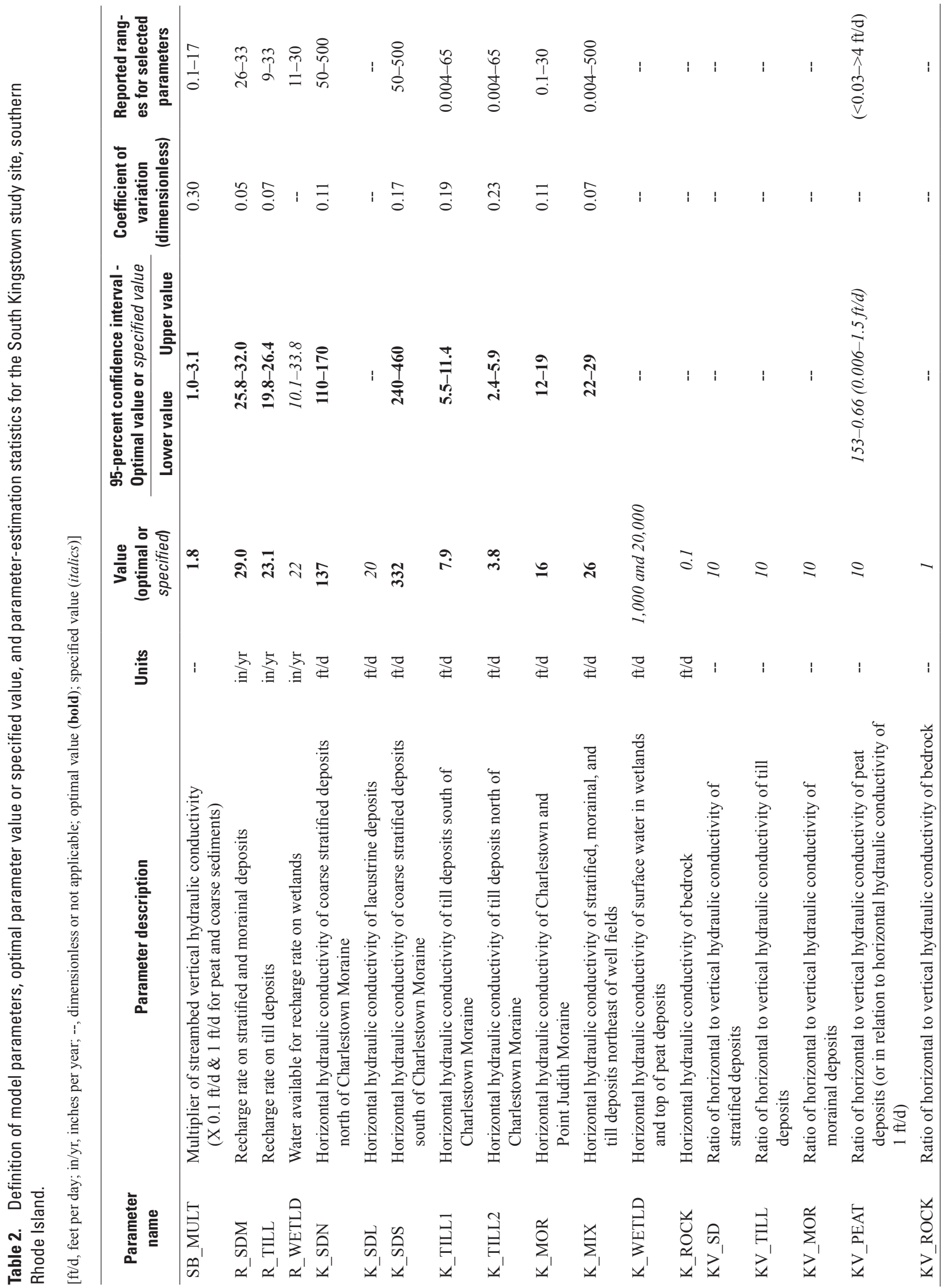
the evaporation rate from a free-water surface ( $29 \mathrm{in} / \mathrm{yr})$ (Farnsworth and others, 1982) from the rate of precipitation for southern Rhode Island (51 in/yr).

Hydraulic conductivity parameters were assigned on the basis of lithology (table 2). Initially, the horizontal hydraulic conductivity of the stratified deposits was represented by three parameters: K_SDN, K_SDL, and K_SDS. K_SDN represented most of the stratified deposits north of the Charlestown Moraine and included the well fields. K_SDL represented the remaining stratified deposits north of the moraine, lacustrine deposits at depth (layer 4) beneath Worden Pond and Great Swamp. K_SDS was the stratified deposits south of the Charlestown Moraine, much of which is coarse-grained sediments. Initially, till and morainal deposits were represented by parameters K_TILL1 and K_MOR1, respectively. Manual calibration and initial parameter-estimation results indicated that glacial deposits in the northeast part of the model - undifferentiated morainal deposits, till northeast of the east well field, and a small area of stratified deposits northeast of these morainal and till deposits (fig. 9) - had different transmissive characteristics than other areas represented by their respective parameters. The extent of the undifferentiated morainal deposits is not well known and may include areas of stratified deposits (Janet Stone, USGS, oral commun., 2007). In addition few data were available to define the bedrock surface in this part of the model. The bedrock-surface altitude also varied substantially between data points when assigning model cell values. These three areas were subdivided into additional parameters, and because optimal values and associated confidence intervals determined by parameter estimation resulted in similar values, these three small areas were combined into one parameter (K_MIX) (fig. 9). Finally, initial model simulations indicated that remaining till north of the Charlestown Moraine would more accurately be represented by subdividing it (K_TILL2) from till south of the moraine.

Horizontal hydraulic conductivity of bedrock was represented by parameter K_ROCK, and wetlands were defined by parameter K_WETLD. Conceptually, K_WETLD can represent overland flow in the wetlands and groundwater flow through any large interconnected pores in poorly decomposed peat in the top part of the peat. Model cells containing freshwater ponds, excluding Worden Pond, were assigned a high hydraulic conductivity value of $50,000 \mathrm{ft} / \mathrm{d}$ to simulate the flat gradient across these water bodies.

The ratio of horizontal hydraulic conductivity to vertical hydraulic conductivity for stratified deposits, morainal deposits, till, bedrock, and peat was each represented by one parameter, KV_SD, KV_MOR, KV_TILL, KV_ROCK, and KV_PEAT, respectively. The horizontal hydraulic conductivity of peat was held constant in the model at $1 \mathrm{ft} / \mathrm{d}$; the ratio is therefore always in relation to this value. KV_PEAT represented the medium and highly decomposed peat at depth that controls the connection between the wetland and the underlying aquifer.

\section{Observations}

The groundwater-flow model was calibrated to 135 water-level observations and 5 streamflow observations. Observations were weighted based on methods described by Hill and Tiedeman (2007); the weights account for measurement error and for the difference in units as between water levels and streamflows. More accurate observations are given larger weights than less accurate observations, and thus have more influence in the regression and estimating parameters. Observation weights are equal to the inverse of the variance (square of the standard deviation) of the measurement. The standard deviation of the measurement error is equal to the accuracy of the measurement divided by the 95-percent confidence interval (1.96) for a normal distribution for surveyed measuring-point altitudes and streamflows or divided by the 90 percent confidence interval (1.65) for a normal distribution for measuring-point altitudes determined from land-surface contours on the USGS Kingston quadrangle.

Water-level observations were divided into three groups (A, B, and C) depending on their estimated accuracy (fig. 9). Group A included two groundwater levels measured on June 15, 2007, and on March 7, 2008, during this study and four groundwater levels made August 20-25, 1959, by Allen and others (1963). The water levels measured on March 7, 2008, and during August 1959 were at average annual groundwater conditions, and the June 15, 2007, water level was near average annual groundwater conditions, according to USGS long-term observation well CHW18 (fig. 6). Accuracy of Group A observations was estimated to be $0.5 \mathrm{ft}$ because altitude datums available from two agencies differed and because a measuring-point altitude common to this study and to Allen and others (1963) also differed. This group of water-level observations was generally evenly distributed over the north half of the modeled area, and they are screened in layer 1 and layer 4 .

Group B included 105 groundwater levels measured from July 1954 to February 1955 (Bierschenk, 1956) and 6 measured from 1957 to 1958 (Allen and others, 1963) at various hydrologic conditions (fig. 6). Water levels measured in summer and early fall are typically at belowaverage levels. During 5 of 8 months when measurements were made during 1954-55, however, water levels at USGS long-term observation well CHW18 were within $1 \mathrm{ft}$ of long-term average because precipitation had been above average during the preceding months. Historical water levels from these studies near the well fields were not included in model calibration because of increased pumping withdrawals since the 1950s; remaining water levels were assumed to be unaffected or minimally affected by the increased pumping rates. Accuracy of Group B groundwater levels, whose measuring-point altitudes were based on land-surface altitude determined from the USGS Kingston quadrangle, is about $5 \mathrm{ft}$ (U.S. Geological Survey, 1980). Because most of these groundwater levels were measured in shallow dug wells, 
they were included in layer 1. In addition to groundwater levels, 11 pond altitudes listed on the USGS Kingston quadrangle, primarily in the Charlestown Moraine, were used in model calibration. These ponds were assumed to be in direct hydraulic connection with the surrounding aquifer and to represent a surface-water expression of the water table. Accuracy of these pond altitudes was also $5 \mathrm{ft}$.

Group C included seven groundwater levels measured at the well-field sites during this study on June 15, 2007, near average groundwater conditions (fig. 6). Four water levels are from the wetland piezometers - two in the peat (layer 2) and two in the stratified deposits (layer 3) - and the remaining water levels are from observation wells in layers 3 and 4 . In addition to discrepancies in elevation that are common with Group A water levels, it is unknown how representative Group $\mathrm{C}$ water levels represent the steady-state pumping conditions, measured near pumping wells that cycle off and on, and with the spatial discretization used in the model. Accuracy of Group C observations was estimated to be $1 \mathrm{ft}$.

Five streamflow observations were measured on June 15, 2007, and March 7, 2008, near average streamflow conditions (fig. 5). The accuracy of these streamflows is about 10 percent. For the Mink Brook observation that represents loss between two sites on the main stem, the total variance was determined by adding the measurement variances. Four small tributary discharges ( 0.01 to $\left.0.03 \mathrm{ft}^{3} / \mathrm{s}\right)$ were not used in model calibration because most of the stream cells upstream of the measuring site were simulated as dry cells.

\section{Estimation of Parameters}

Model parameters included three for recharge, nine for horizontal hydraulic conductivity, five for vertical anisotropy, and one for streambed hydraulic conductivity (multiplier of streambed conductivity) (table 2). Parameter R_WETLD, which represented water available for recharge in the wetlands, was specified in the model at the beginning of model calibration, but the uncertainty in the parameter value was included in the uncertainty analysis.

Parameter sensitivities, shown by their composite scaled sensitivities in figure 10, indicate whether water level and streamflow observations provided sufficient information to estimate a given parameter (Hill and Tiedeman, 2007). In addition, parameters with higher sensitivities generally can be more precisely estimated than can parameters with lower sensitivities. Parameters with composite scaled sensitivities that are about two orders of magnitude lower than that of the parameter with the highest value indicate that nonlinear regression may not be able to estimate the parameter (Hill and Tiedeman, 2007). Low sensitivities were associated with all the parameters for vertical anisotropy and thus were assigned values from the literature. The ratios of horizontal to vertical hydraulic conductivity of glacial deposits (KV_SD, KV_TILL,

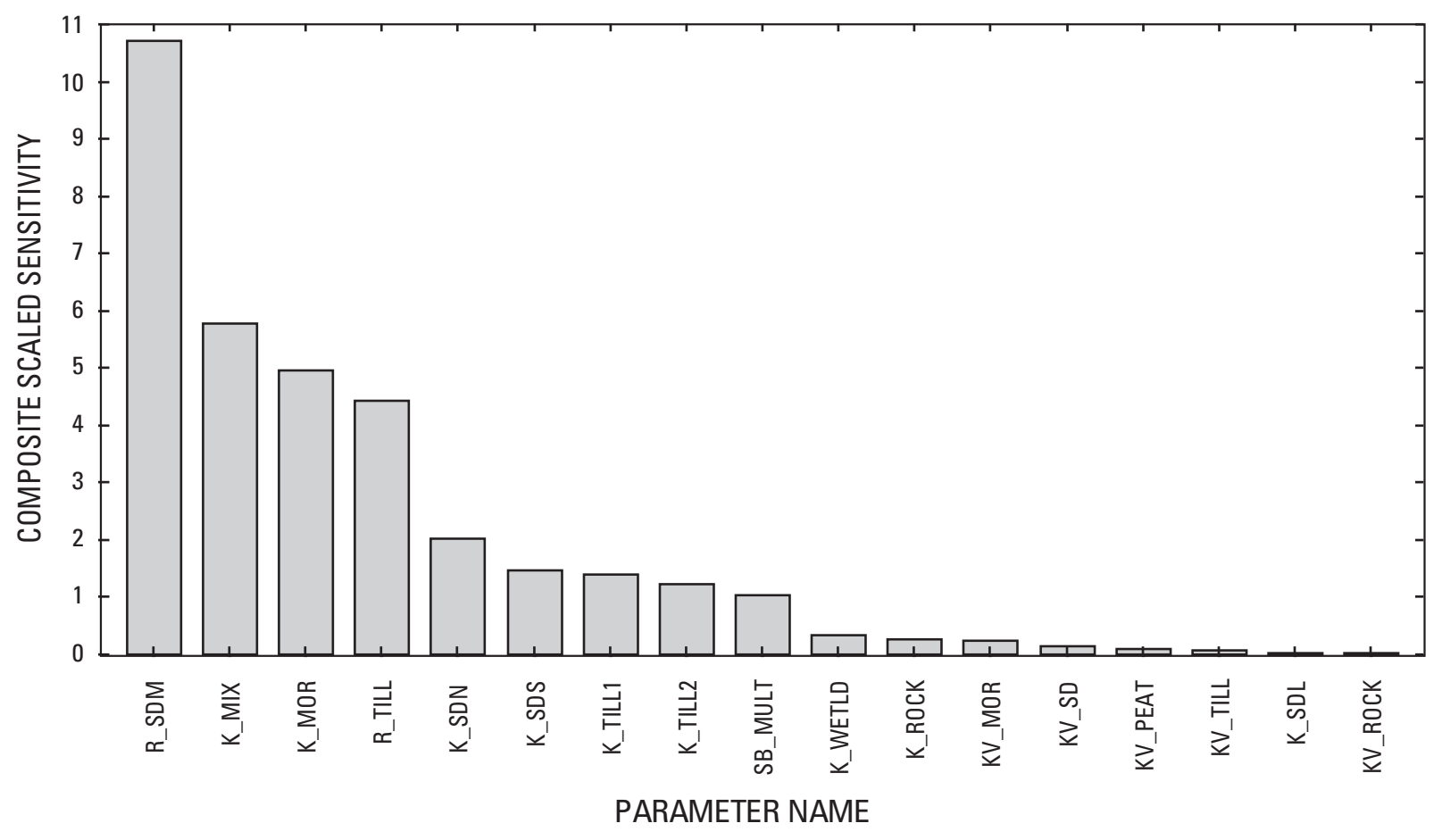

Figure 10. Composite scaled sensitivities for model parameters (parameter information is provided on table 2), South Kingstown study site, southern Rhode Island. 
KV_MOR) and of peat (KV_PEAT) were set to 10; because the horizontal hydraulic conductivity of peat was set to $1 \mathrm{ft} / \mathrm{d}$, the resulting vertical hydraulic conductivity was equivalent to $0.1 \mathrm{ft} / \mathrm{d}$, which lies between peat values determined from field measurements in southern Rhode Island. KV_ROCK was specified a ratio of 1 . Low sensitivities were also associated with three of the parameters for horizontal hydraulic conductivity (K_SDL, K_ROCK, and K_WETLD). K_SDL was set to $20 \mathrm{ft} / \mathrm{d}$, representative of very fine sand sediments, and $\mathrm{K} \_$ROCK was set to a low value of $0.1 \mathrm{ft} / \mathrm{d}$. The wetlands were subdivided into two areas. Great Swamp was set to $20,000 \mathrm{ft} / \mathrm{d}$ based on manual calibration so as to flatten the hydraulic gradient across this wetland. The remaining smaller wetland areas were fixed at $1,000 \mathrm{ft} / \mathrm{d}$, a value at the low end of a range of hydraulic conductivities that Masterson and others (2007) determined by manual calibration for wetlands in southern Rhode Island. Conceptually, Great Swamp may have more open water and less resistance to flow than smaller wetland areas. None of the remaining nine recharge and hydraulic parameters was highly correlated (parameter correlation coefficient greater than 0.95), and thus these parameters were estimated by nonlinear regression.

The quality of model calibration can be determined through analysis of the weighted residuals, both numerically and graphically; Hill and Tiedeman (2007) describe this analysis in detail. Weighted residuals should be randomly distributed and close to zero. The average weighted residual was $-0.17 \mathrm{ft}$ for the model and ranged from a minimum of $-9.5 \mathrm{ft}$ to a maximum of $5.9 \mathrm{ft}$. The sum of squared weighted residuals was 696 for the calibrated model. The calculated error variance and the standard error of the regression (square root of the calculated error variance), which are measures of the overall magnitude of the weighted residuals, were 5.32 and 2.31 , respectively; theoretically, these values should be equal to one, but commonly that is not the case for groundwater models (Hill and Tiedeman, 2007).

Weighted residuals and weighted simulated values for both water level and streamflow observations are shown in figure 11A. A comparison of weighted residuals indicated that residuals are generally evenly distributed above and below a value of zero for all weighted simulated values. Furthermore, 131 of 140 observations are within two standard errors of the regression. The relation between weighted observed values and weighted simulated values is shown in figure 11B. Most values plot near a line with a 1:1 slope; the correlation between weighted observed values and weighted simulated values was 0.99 . The spatial distribution of weighted water level and streamflow residuals is shown in figure 12. Weighted residuals are generally distributed randomly throughout most of the modeled area. In the southeast part of the modeled area, however, there are areas with clusters of negative residuals (simulated water levels are greater than observed water levels) near boundaries represented by a constant head of zero feet.

Insights into observations most important to the parameter estimates were calculated from influence statistics Cook's D and DFBeta using the RESAN-2000 program
(Hill and others, 2000). Observations with the most overall influence in the regression and the resulting set of estimated parameters were determined from Cook's D statistics. Thirteen observations ( 9 water levels and 4 streamflows) had a Cook's $\mathrm{D}$ value greater than the critical value of 0.028 (4 divided by the number of observations); these influential observations are shown in figure 12 . The observations with the most overall influence in the parameter estimation are generally distributed throughout the northern half of the model, which is the area of greatest interest. Four of the five streamflow observations were considered influential, thus indicating the importance of streamflows in model calibration. The Mink Brook seepage observation, although important to a few individual estimated parameters according to DFBeta statistics, was not among the 13 most influential observations. Because the accuracy of the Mink Brook streamflow measurements was small compared to the measured loss, the weight on this seepage observation was small and thus did not affect the regression as much as did the other streamflow observations.

Optimal values for the nine recharge and hydraulic parameters that were estimated using nonlinear regression are listed in table 2. The optimal values are within the range of values reported in the literature, as discussed in the sections "Hydraulic Properties" and "Recharge Rates." Recharge to stratified deposits and morainal deposits (R_SDM), $29.0 \mathrm{in} / \mathrm{yr}$, is within the range of mean annual runoff rates determined from long-term USGS streamgages in southern Rhode Island. Recharge to till uplands (R_TILL), $23.1 \mathrm{in} / \mathrm{yr}$, is within the range of recharge rates from till-dominated watersheds in southern New England, as calculated from computerized hydrograph-separation methods. Parameter K_SD1 represents most stratified deposits north of the Charlestown Moraine and is close to the median value determined from aquifer tests at the east well field. Optimal values for the remaining horizontal hydraulic conductivities are close to expected values, except for K_MIX, which represents undifferentiated morainal deposits, till, and stratified deposits in the northeast part of the model. The optimal value of $26 \mathrm{ft} / \mathrm{d}$ is at the high end of the acceptable range for till, and indicated additional data to define the bedrock surface may be needed to more accurately simulate this area. The dimensionless multiplier of streambed vertical hydraulic conductivity, SB_MULT, is equivalent to $1.8 \mathrm{ft} / \mathrm{d}$ for coarse-grained bed sediments and to $0.18 \mathrm{ft} / \mathrm{d}$ for Mink Brook organic-rich bed sediments.

The precision or uncertainty of the parameter estimate is indicated by the 95-percent linear confidence interval for each optimal value (table 2). For these linear confidence intervals to be valid, weighted residuals should be normally distributed and the model linear near the estimated optimal values (Hill and Tiedeman, 2007). If weighted residuals are independent and normally distributed, they plot on an approximately straight line on a normal probability graph. The correlation between weighted residuals and the normal order statistics for the calibrated model was 0.962 . This value is less than the critical value for 140 observations, 0.981 , at the 5 percent significance level. Weighted residuals can be normally 

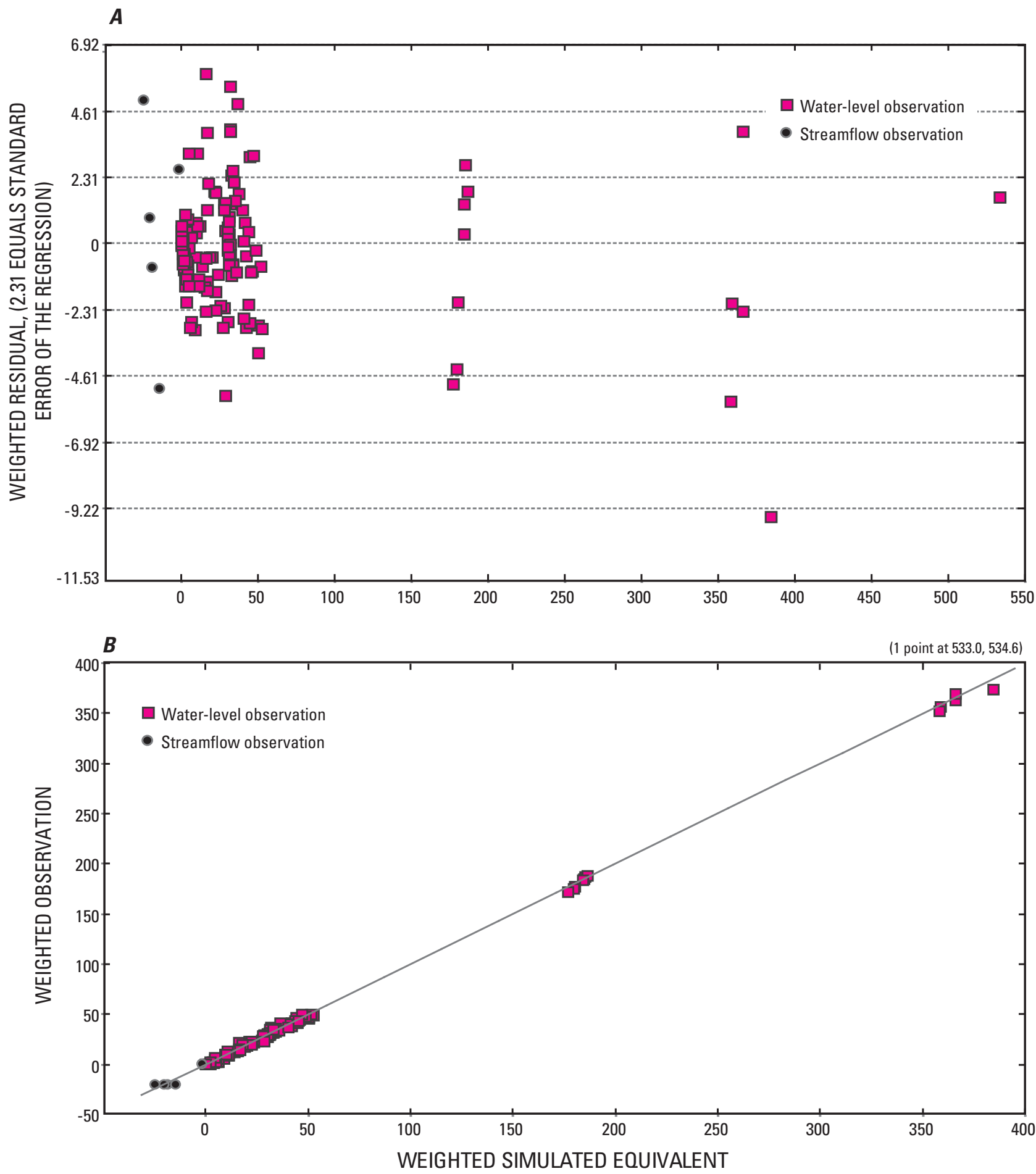

Figure 11. Relation of $A$, weighted residual to weighted simulated equivalent and of $B$, weighted observation to weighted simulated equivalent, South Kingstown study site, southern Rhode Island. 


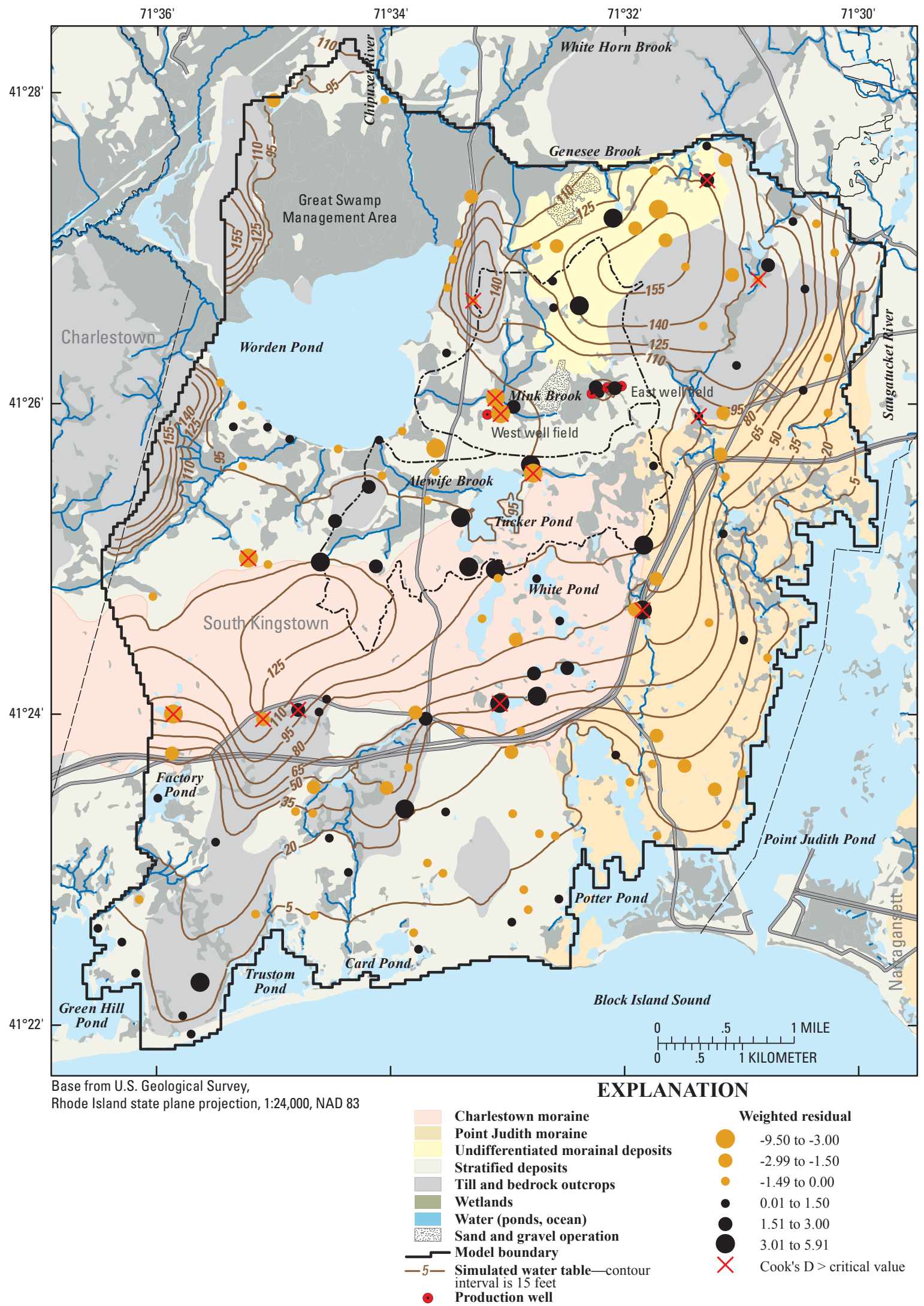

Figure 12. Spatial distribution of weighted residuals and simulated water-table contours for calibrated, steadystate conditions, South Kingstown study site, southern Rhode Island. 
distributed, but they are correlated because of the fitting of the regression (Hill and Tiedeman, 2007). Weighted residuals can be compared to sets of randomly generated weighted residuals with the same degree of correlation as expected for the model using the RESAN-2000 program (Hill and others, 2000). The calibrated model did produce weighted residuals that are normally distributed based on this comparison with the generated residuals. The degree of model linearity can be quantified using the modified Beale's measure, calculated with the BEALE-2000 program (Hill and others, 2000). The model is considered effectively linear if the modified Beale's measure is less than 0.046 and nonlinear if it is greater than 0.51 . The modified Beale's measure for the model was 0.249 and indicated that the model is moderately linear. The confidence intervals listed in table 2 are thus approximate values.

The 95-percent confidence intervals for the parameter estimates are all within the ranges of reasonable values reported in the literature. A comparison of the relative precision of different parameter estimates can be made using the coefficient of variation (standard deviation of the estimate divided by the optimal value) (table 2); a smaller coefficient of variance indicates a more precisely estimated parameter. The coefficient of variations ranged from 0.05 to 0.30 . Recharge parameters R_SDM and R_TILL and horizontal hydraulic conductivity parameter K_MIX, all with coefficient of variation values less than 0.1 , were the most precisely estimated, whereas the streambed multiplier SB MULT, with a coefficient of variation of 0.30 , was the least precisely estimated. Of the remaining parameters, K_SDN and K_MOR were more precisely estimated than K_SDS, K_Till1, and K_TILL2. The order of the most to least precisely estimated parameter values generally follows the same order as that of the parameter sensitivities (fig. 10) because of the information provided by the observations in the regression.

\section{Simulated Water-Table Contours and Water Budget}

The altitude and configuration of the simulated water table for the calibrated model are shown in figure 12 at $15-\mathrm{ft}$ contour intervals. The simulated water-table contours and flow directions are consistent with the conceptual model of groundwater flow in the study area and with simplified water-table maps drawn by Bierschenk (1956) and Allen and others (1966). Groundwater flows from topographically high areas and discharges to streams and surface-water bodies. The water-table gradient is steepest in the till uplands and morainal deposits, and then it flattens in the more transmissive valleyfill areas of stratified deposits and wetlands. In the till uplands and morainal deposits, simulated groundwater divides are in the general area of topographically defined watershed divides.

The simulated groundwater budget for the calibrated model indicated that recharge from direct precipitation provides $52.4 \mathrm{ft}^{3} / \mathrm{s}$, which constitutes 95 percent of the inflow. Streamflow loss accounts for the remaining inflow,
$2.8 \mathrm{ft}^{3} / \mathrm{s}$ or 5 percent. Most of this streamflow loss occurs near abrupt changes in transmissivity, such as at the contact between upland till and stratified deposits. Of the total inflow, $14.8 \mathrm{ft}^{3} / \mathrm{s}$ (27 percent) eventually discharges to streams and Worden Pond in the Chipuxet River watershed, and $4.8 \mathrm{ft}^{3} / \mathrm{s}$ (9 percent) is withdrawn by the UWRI production wells. The remaining outflow, $35.6 \mathrm{ft}^{3} / \mathrm{s}$ (64 percent) discharges to streams, coastal ponds, and Block Island Sound in the South Coastal watershed.

\section{Deterministic Areas Contributing Recharge}

Simulated deterministic areas contributing recharge and groundwater traveltimes to the UWRI well fields were determined on the basis of the calibrated steady-state model, for simulated pumping conditions, and tracking of pathlines with the MODPATH particle-tracking program. The areas contributing recharge to the well fields are based on both well fields pumping simultaneously. If one of the well fields stops pumping, or if withdrawal rates change, then the contributing area to the well fields would also change. The locations and extents of the simulated areas contributing recharge to each well field pumping at the 2003-07 average annual rate and the maximum rate (table 1) are shown in figures 13 and 14 . The total maximum pumping rate for the well fields, $5,100 \mathrm{gal} / \mathrm{min}$, is about 2.4 times greater than the 2003-07 average rate of $2,138 \mathrm{gal} / \mathrm{min}$.

The total area contributing recharge for the average pumping rate covers about $2.30 \mathrm{mi}^{2}$ and includes small isolated areas. The contributing area extends to groundwater divides in mostly till and morainal deposits north, east, and south of the well fields. Most of the sand and gravel mining operation between the well fields is in the contributing area to the wells. The well fields derive most of their water from direct precipitation recharge. A water-balance calculation (a comparison of pumping withdrawals to the size of the contributing area and recharge rates) indicated that infiltration from the narrow streams accounted for about 3 percent of the pumped water. Pumping withdrawals reduced groundwater discharge and surface water by the amount pumped.

In some areas near simulated streams in Mink and Alewife Brook watersheds, including part of the sand and gravel mining operation, precipitation recharge discharges to streams instead of being captured by the well fields. In addition, most of Tucker Pond is not in the simulated contributing area because of the method used to simulate Alewife Brook. Alewife Brook was simulated flowing through Tucker Pond and with a high streambed conductance in order to route water to downgradient cells and to minimize the gradient across the pond. Because the pond is part of the contributing area to the west well field, all areas that contribute water to the pond can potentially contribute water to this well field.

At the maximum pumping rate, the area contributing recharge (5.54 $\left.\mathrm{mi}^{2}\right)$ expands in all directions to capture enough water to balance the pumping rate. As was mentioned 


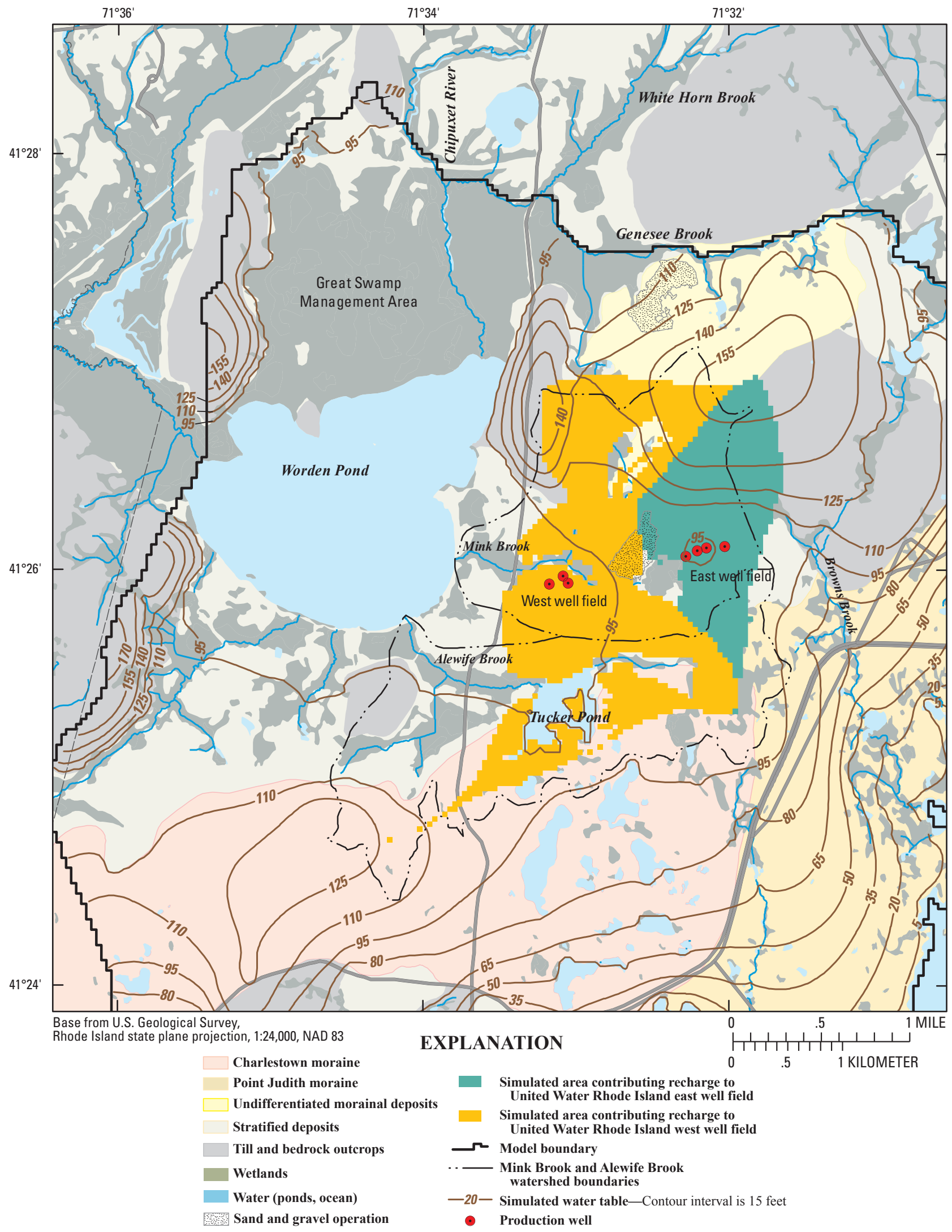

Figure 13. Simulated areas contributing recharge to the United Water Rhode Island east and west well fields at their total average pumping rate of 2,138 gallons per minute, South Kingstown study site, southern Rhode Island. 


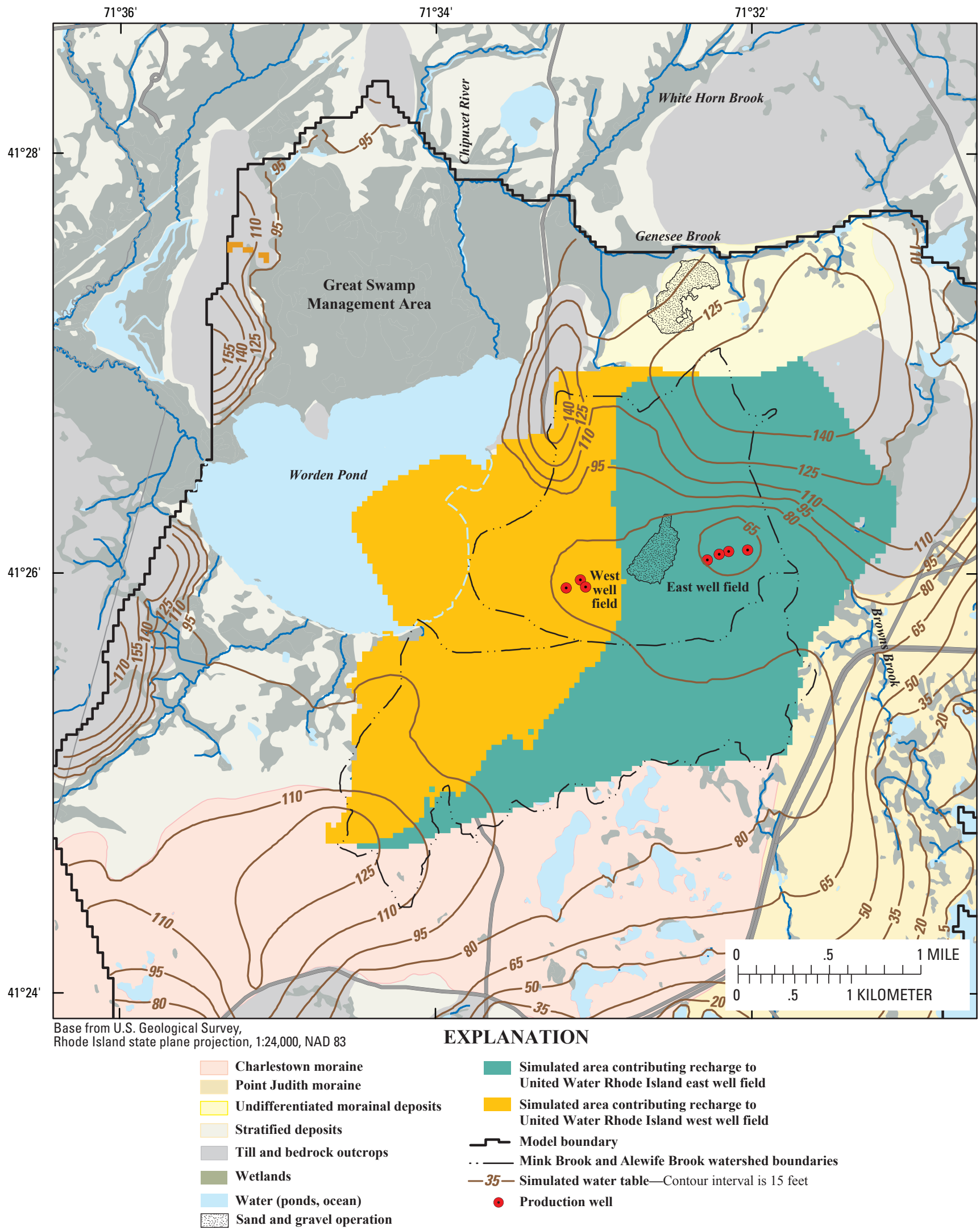

Figure 14. Simulated areas contributing recharge to the United Water Rhode Island east and west well fields at their total maximum pumping rate of 5,100 gallons per minute, South Kingstown study site, southern Rhode Island. 
previously in the "Hydrology" section, the maximum pumping rate exceeds the total water available for recharge in the Mink and Alewife watersheds. Thus the well fields intercepted most of the precipitation recharge in these watersheds, and simulated streams ceased to flow. The entire sand and gravel mining operation between the well fields is in the contributing area. The maximum pumping rate also shifts the simulated groundwater divides and captures groundwater that would have discharged to adjacent watersheds under average pumping conditions. The contributing area also extends beneath and beyond Browns Brook in the South Coastal watershed east of the well fields.

The area contributing recharge extends westward or downvalley beneath Worden Pond and also includes an isolated area remote from the well fields on the opposite side and northwest of Worden Pond in upland till. Particle tracks indicate that recharge originating in these till uplands travels along deep groundwater-flow paths in the stratified deposits and, under pumping conditions, passes beneath Worden Pond to the west well field. Recharging water between this isolated contributing area and Worden Pond travels along shallow depth flow paths before discharging to Worden Pond. Similarly, particles along the southwest edge of the contributing area south of Worden Pond also track beneath the pond before discharging to the west well field. Similar to Tucker Pond, because Worden Pond is part of the contributing area to the west well field, all areas that contribute water to the pond can potentially contribute water to this well field. The well fields derived most of their water from direct precipitation recharge, but about 12 percent of the pumped water is from surface water, primarily Worden Pond. This surface-water infiltration is about 4 percent of the long-term average streamflow calculated for the Chipuxet River at its confluence with White Horn Brook.

Simulated traveltime estimates from recharging locations to the production wells for the maximum pumping rate are shown in figure 15. Estimated traveltimes are based on porosities of 0.35 for stratified, till, and morainal deposits; 0.80 for peat deposits; 0.02 for bedrock; and 1 for surface water. Porosity values only affect groundwater velocity and do not change the contributing areas to the wells. Traveltimes ranged from less than 1 year to more than 500 years;

59 percent of the traveltimes were 10 years or less, 75 percent were 20 years or less, 89 percent were 40 years or less, 96 percent were 100 years or less, and about 1 percent was greater than 500 years. The median traveltime to the east well field, screened in shallower sediments and closer to groundwater divides than the west well field, was 6.0 years or about one-half the median traveltime to the west well field, 11 years; traveltimes to both well fields combined had a median value of 7.6 years. Water that recharges the aquifer near the well fields has the shortest traveltimes, whereas water originating in the southwest, in the till uplands northwest of Worden Pond, and at the edge of the contributing area beneath Worden Pond has the longest traveltimes. The shortest traveltimes from the nearest large ponds are 5 years for Tucker Pond and 8 years for Worden Pond.

Advantages and disadvantages of using a fixed transmissivity for all model layers were summarized in the "Numerical Modeling" section. A disadvantage is that the simulated transmissivity of the aquifer near the well fields does not decrease with increased drawdowns that the maximum pumping rates cause. Near the west well field, which is in thick sediments near the preglacial-valley axis, the difference between the simulated saturated thickness for the pumping rate used in the calibrated model and the maximum pumping rate was minimal (less than 10 percent), but in the vicinity of the east well field, which is near the valley-upland contact, saturated thickness decreased from about $70 \mathrm{ft}$ to $40 \mathrm{ft}$. Thus, groundwater traveltimes and areas contributing recharge to the well field may be different for a model that uses fixed transmissivity compared to one that uses variable transmissivity. However, if a variable transmissivity model had similar drawdowns as the fixed transmissivity model, then using a horizontal hydraulic conductivity value of $240 \mathrm{ft} / \mathrm{d}$ would have a transmissivity equivalent to that of the fixed transmissivity model. Although this hydraulic conductivity value is greater than the upper 95-percent confidence limit estimated by parameter estimation, it is within the range of values (100 to $400 \mathrm{ft} / \mathrm{d}$ ) calculated from aquifer tests at the well field. Also, the response of nearby surface-water bodies to pumping would probably be the same for either a fixed transmissivity or a variable transmissivity because at pumping rates as high as the maximum rates, all the groundwater was intercepted by the well field before discharging to the nearby stream.

\section{Probabilistic Areas Contributing Recharge}

The deterministic areas contributing recharge were based on estimated and specified parameter values. Parameter values were estimated using available observations or they were specified from reported values in the literature. Information on model parameters is provided in table 2. Different degrees of uncertainty are associated with these estimated parameter values, and additional observations may increase the precision of these estimates. Parameter uncertainty and its associated effects on the simulated contributing area can be evaluated by a stochastic Monte Carlo analysis. The parameter variancecovariance matrix from nonlinear regression can be used to create plausible parameter sets for the Monte Carlo analysis (Starn and others, 2000). The parameter variance-covariance matrix captures the uncertainty of the parameter estimates and the correlation among parameters from the calibrated model. Parameter values for the Monte Carlo analysis were created by the following equation (Starn and others, 2000): 


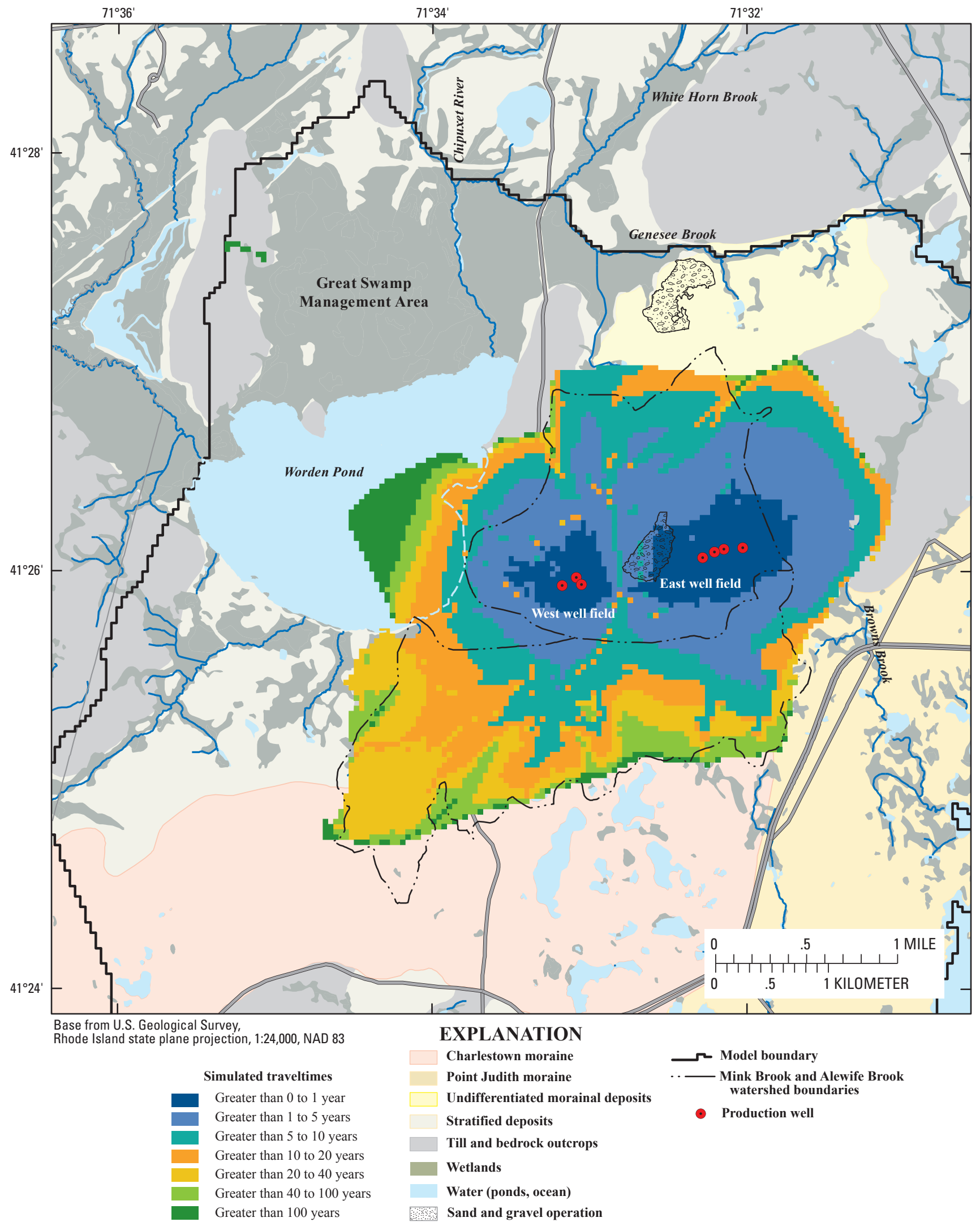

Figure 15. Simulated traveltimes to the United Water Rhode Island well fields at their maximum pumping rate of 5,100 gallons per minute, South Kingstown study site, southern Rhode Island. 


$$
b=z \sigma+\mu,
$$

where

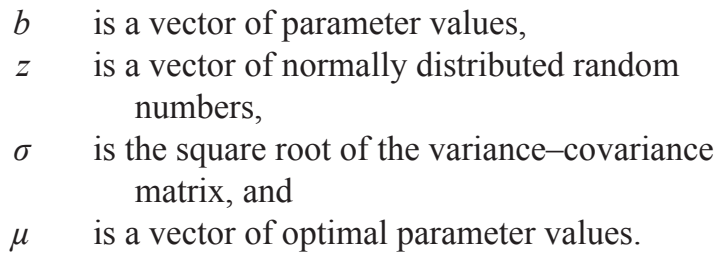

Parameter values that could not be estimated by nonlinear regression and thus were not included in the parameter variance-covariance matrix of the calibrated model may still be important for model predictions (for this study the size, shape, and location of the area contributing recharge to the production wells). Previous studies of areas contributing recharge to production wells in various glacial valley-fill settings in Rhode Island (Friesz, 2004; Friesz and Stone, 2007) indicated that recharge rates, the hydraulic connection between surface water and the underlying aquifer, and the horizontal hydraulic conductivity of the aquifer were the most important hydrologic factors that affected the simulated contributing area. A sensitivity analysis confirmed that unestimated parameters representing anisotropy of glacial deposits and bedrock had little or no effect on the simulated contributing area to the wells for a plausible range of values. In addition, two horizontal hydraulic conductivity parameters, K_SDL and K_ROCK, had little or no effect on the simulated contributing area. The contributing area did show various degrees of sensitivity to different values for R_WETLD and KV_PEAT, especially at the maximum pumping rate scenario. These two parameters were incorporated into the variance-covariance matrix using the specified parameter values; the observations provided enough information to constrain the uncertainty of these parameters around the specified values within a realistic range for these highly variable and poorly understood parameters. The lower and upper 95-percent confidence intervals were 10.1 and $33.8 \mathrm{in} / \mathrm{yr}$ for R_WETLD and 153 and 0.66 for KV_PEAT (equivalent to vertical hydraulic conductivity of 0.006 and $1.5 \mathrm{ft} / \mathrm{d}$ for peat) (table 2). Thus, all parameter uncertainty important for model prediction was incorporated into the Monte Carlo analysis, and the available observations constrained this uncertainty.

The parameter sets created by equation 1 are shown in figure 16A for hydraulic parameters and in figure 16B for recharge parameters. The hydraulic parameters were log-transformed in the model. The parameter sets have a lognormal or normal distribution around the optimal or specified parameter value; the spread of these data indicates the certainty with which the parameter could be estimated with the available observations. The KV_PEAT has the least certainty of the hydraulic parameters, and R_WETLD has the least certainty of the recharge parameters. Parameter sets with a KV_PEAT value two orders of magnitude greater or less than the specified value of 10 (a vertical conductivity of $0.1 \mathrm{ft} / \mathrm{d}$ for peat) were considered unrealistic for the full vertical thickness of the peat layer and were thus removed (conditioned) from the parameter sets. This accounted for 14 percent of the parameter sets.

For the Monte Carlo analysis, the model was run with 1,000 parameter sets and the average pumping rate. The eleven hydraulic and recharge parameter values in each dataset replaced corresponding parameter values in the calibrated model. Three acceptance criteria were used: (1) model had to converge, (2) model mass balance was 0.5 percent or less, and (3) calculated error variance was less than a specified value. The third acceptance criterion was varied in order to evaluate model fit to observations. This model-fit statistic was used so that model-prediction uncertainty would not be overestimated by using a parameter set having an extremely large calculated error variance. Table 3 summarizes the Monte Carlo analysis with calculated error variances in increments of five. The number of MODFLOW runs and the total size of the probabilistic contributing area increased minimally from a calculated error variance of 15 to 20 , and for this model, from 15 to using a water budget as the only criterion. For this application of the Monte Carlo analysis, the probabilistic contributing area with a calculated error variance of 20 (same area as if only using the water budget criterion) was used. Of the 1,000 parameter sets run with MODFLOW, 749 fit the acceptance criteria. The distribution of hydraulic parameters and recharge parameters after the acceptance criteria were applied (fig. 17), although slightly altered from the original parameter sets, indicated a generally lognormal or normal distribution. The probability that a recharge location would be in the area contributing recharge to the production wells was determined by dividing the number of times a particle at a given location was captured by a well by the total number of accepted particle-tracking simulations; this probability was expressed as a percentage.

The probabilistic contributing area to the production wells for the average pumping rate is illustrated in figure 18 . The total size of the probabilistic contributing area is larger than the deterministic contributing area because of the effects of parameter uncertainty. Areas with high probabilities (greater than 50 percent) generally coincide with the deterministic contributing area. Low probabilities indicate that observations used in the model calibration are not sufficient for determining whether a location is within or outside of the contributing area (Starn and others, 2000). Low probabilities are in areas distant from the production wells and in areas where simulated streams intercepted precipitation recharge in the deterministic model. Along margins of the probabilistic contributing area north and east of the production wells, there is less spread in low probabilities than south of the wells in areas near groundwater divides. This is most likely because a change in horizontal hydraulic conductivity results in less of a change in transmissivity in the thinner surficial deposits north and east of the wells than in the southern part of the contributing area, which is in and near the main bedrock valley axis. Southwest of the wells, a large spread in low probabilities extends to an area that was a groundwater mound in the calibrated model; 

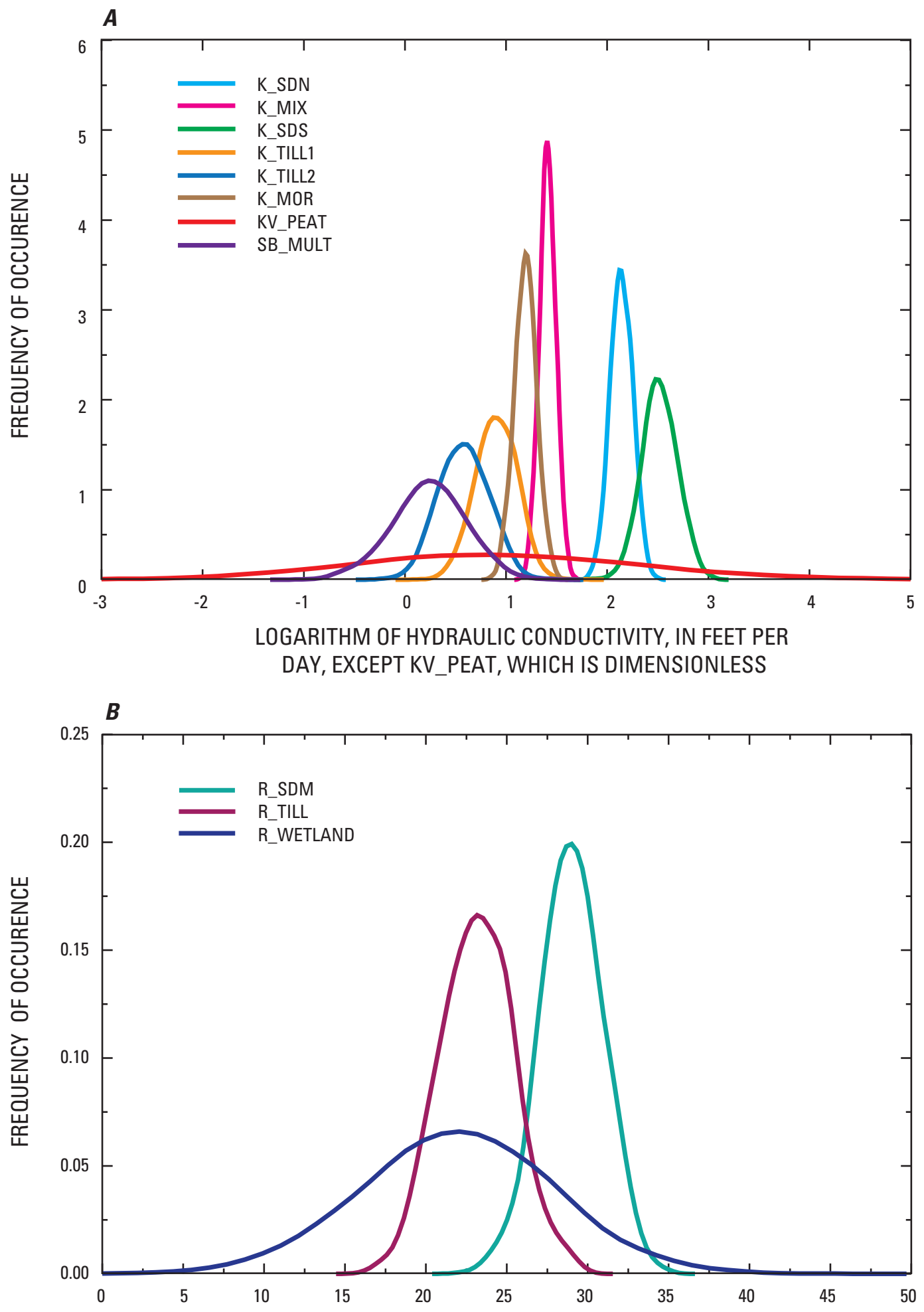

RECHARGE RATE, IN INCHES PER YEAR

Figure 16. Frequency distribution of $A$, hydraulic parameters, and of $B$, recharge parameters, before acceptance criteria were applied to determine the probabilistic areas contributing recharge to the United Water Rhode Island well fields (parameter information is provided on table 2), South Kingstown study site, southern Rhode Island. 
Table 3. Summary of the Monte Carlo analysis for the South Kingstown study site, southern Rhode Island.

[UWRI, United Water Rhode Island; $\mathrm{mi}^{2}$, square mile; KV_Peat, ratio of horizontal to vertical hydraulic conductivity of peat deposits; K_SDL, horizontal hydraulic conductivity of lacustrine deposits]

\begin{tabular}{|c|c|c|c|c|}
\hline \multirow{2}{*}{ Comment } & \multirow{2}{*}{$\begin{array}{l}\text { Calculated } \\
\text { error variance } \\
\text { criterion }\end{array}$} & \multirow{2}{*}{$\begin{array}{l}\text { Number of parameter } \\
\text { sets run with } \\
\text { MODFLOW: } \\
\text { Number of parameter } \\
\text { sets that fit criteria' }\end{array}$} & \multicolumn{2}{|c|}{$\begin{array}{l}\text { Total size of probabilistic } \\
\text { contributing area to } \\
\text { UWRI wells }\end{array}$} \\
\hline & & & $\begin{array}{l}\text { Number of } \\
\text { particles or cells }\end{array}$ & $\begin{array}{l}\text { Area } \\
\left(\mathrm{mi}^{2}\right)\end{array}$ \\
\hline \multicolumn{5}{|c|}{ Average pumping rate } \\
\hline KV_Peat conditioned & 10 & $1,000: 662$ & 4,609 & 3.72 \\
\hline KV_Peat conditioned & 15 & $1,000: 744$ & 4,925 & 3.97 \\
\hline KV_Peat conditioned & 20 & 1,000:749 & 5,043 & 4.07 \\
\hline KV_Peat conditioned & None & $1,000: 749$ & 5,043 & 4.07 \\
\hline $\begin{array}{l}\text { Prior information on glacial anisotropy parameters and K_SDL; } \\
\text { KV_Peat and glacial anisotropy parameters conditioned }\end{array}$ & 20 & $1,000: 714$ & 5,027 & 4.06 \\
\hline \multicolumn{5}{|c|}{ Maximum pumping rate } \\
\hline $\begin{array}{l}\text { Parameter sets that fit selected water budget and calculated error } \\
\text { variance criteria for average pumping rate }\end{array}$ & None & 749:629 & 9,999 & 8.07 \\
\hline
\end{tabular}

${ }^{1}$ Criteria: (1) model converged, (2) mass balance 0.5 percent or less, and (3) for some cases, a calculated error variance less than a specified value.

the deterministic contributing area in this area corresponded to low probabilities including 10 percent or less. The probabilistic contributing area indicated that precipitation recharge that discharged to streams in the Mink and Alewife watersheds in the deterministic model may go directly to a well. These areas include some high probabilities. That part of the sand and gravel mining operation between the well fields that is not in the deterministic contributing area is in the probabilistic contributing area including high probabilities.

A second Monte Carlo analysis was done with production wells at average pumping rates. This analysis included the remaining glacial hydraulic parameters in the parameter variance-covariance matrix in order to verify that these parameters have little effect on the uncertainty analysis. Bedrock parameter values were not changed in this analysis. Incorporating parameters representing glacial anisotropies (KV_SD, KV_Till, and KV_Mor) and K_SDL into the parameter variance-covariance matrix caused large unrealistic uncertainties around the specified parameter values. Prior information for these parameters (see sections "Hydraulic Properties" and "Recharge Rates") was used to constrain this uncertainty. A prior weight was used for the glacial anisotropies so that the 95-percent confidence interval was greater than 1 and less than or equal to 80. Prior weight for K_SDL was \pm 75 percent around the specified value of $20 \mathrm{ft} / \mathrm{d}$. The parameter sets created with equation 1 were then conditioned for unrealistic KV_Peat values as before, but they were also conditioned to remove parameter sets with glacial anisotropies less than 1 or greater than 100 , which were considered unrealistic. The results of this second Monte Carlo analysis (table 3; probabilistic contributing area not shown) confirmed that uncertainty in these four parameters had little effect on the results for the probabilistic contributing area. The general pattern in high to low probabilities was the same in both analyses, and the total area was also almost the same (4.06 $\mathrm{mi}^{2}$ compared to $4.07 \mathrm{mi}^{2}$ ).

A Monte Carlo analysis with the maximum pumping rate was done by using the parameter sets that fit the acceptance criteria for the average pumping rate. The only criterion for the Monte Carlo analysis that used these 749 parameter sets with the maximum pumping rate was a water budget of 0.5 percent or less. Of the 749 parameter sets, 629 parameter sets (84 percent) fit this criterion and thus were run with the particle tracking program (table 3 ). Areas with probabilities greater than 50 percent generally coincide with the deterministic contributing area (fig. 19). Generally, areas closest to the production wells with short traveltimes are associated with high probabilities, whereas areas distant from the wells with long traveltimes are associated with low probabilities. The sand and gravel mining operation between the well fields and within the deterministic contributing area has a probability of 100 percent. A sand and gravel mining operation north of the well fields in Genesee Brook watershed is not within the deterministic contributing area, but the Monte Carlo analysis indicated that part of this sand and gravel mining operation may be in the contributing area (probabilities of 2 percent and less).

Some areas north and south of Worden Pond that are not in the deterministic contributing area are in the probabilistic contributing area. These are areas of mostly low probabilities. The sensitivity analysis described earlier showed that, by decreasing either the recharge rates or the 

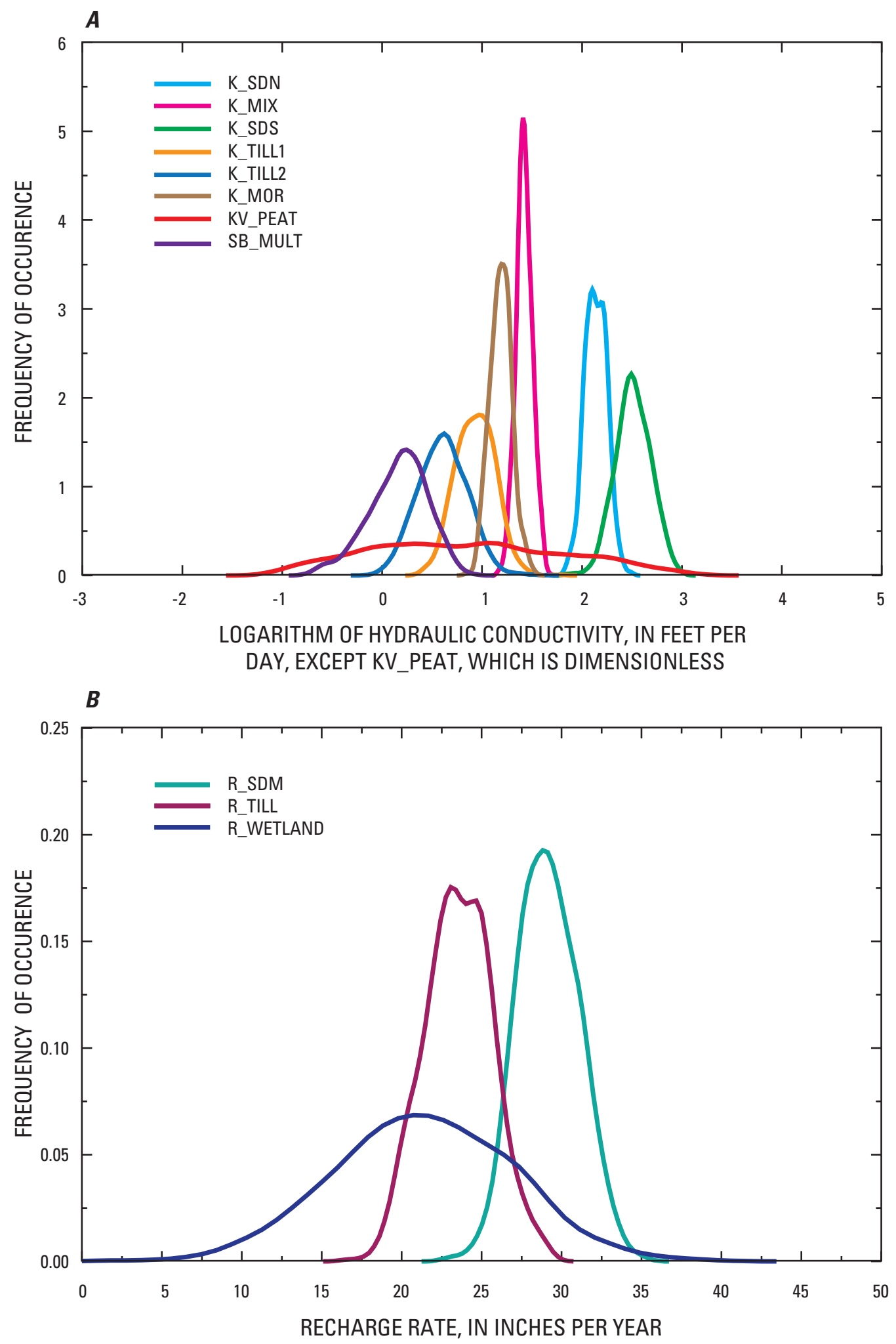

Figure 17. Frequency distribution of $A$, hydraulic parameters, and of $B$, recharge parameters, after acceptance criteria were applied to determine the probabilistic areas contributing recharge to the United Water Rhode Island well fields (parameter information is provided on table 2), South Kingstown study site, southern Rhode Island. 


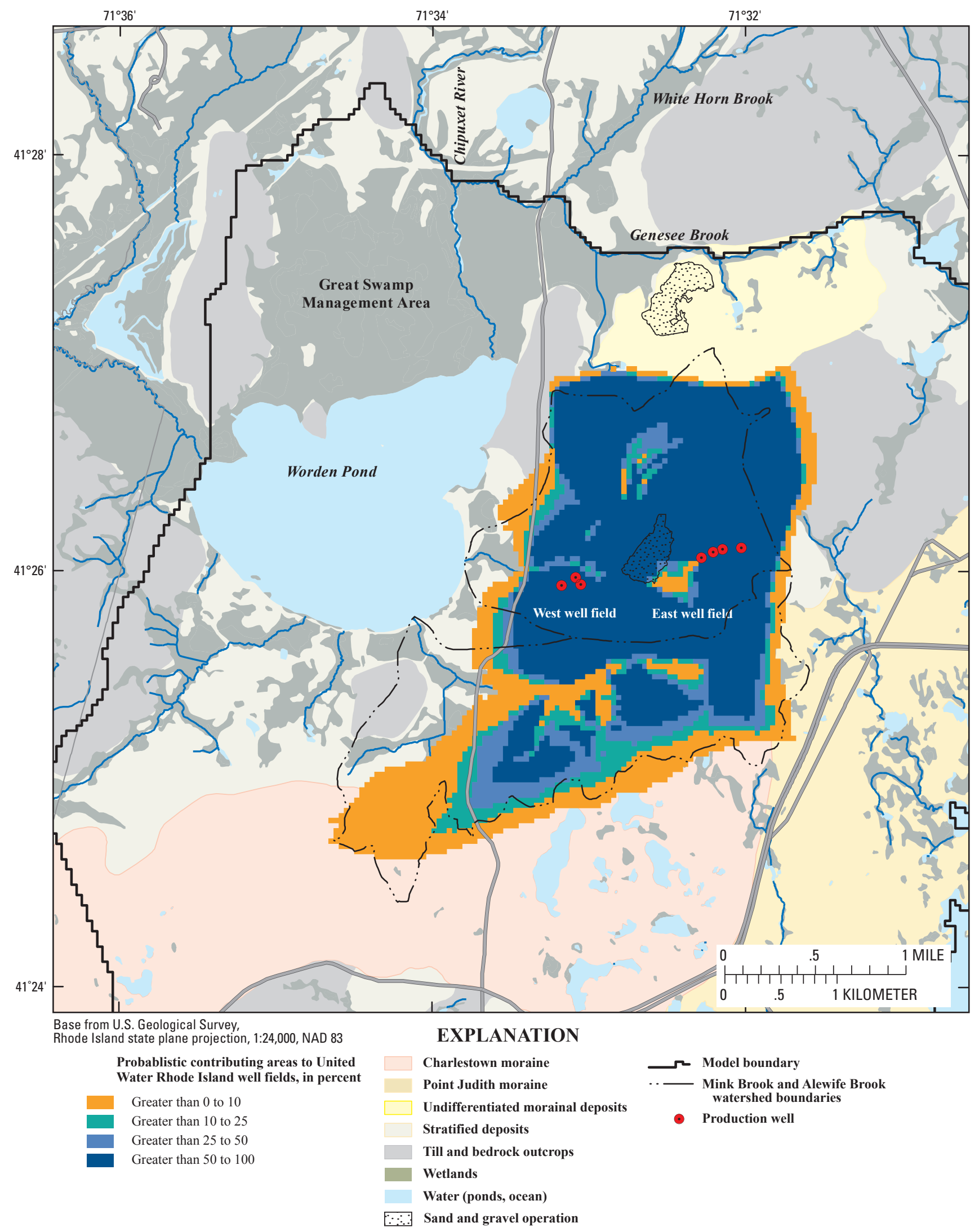

Figure 18. Simulated probabilistic areas contributing recharge to the United Water Rhode Island well fields at their total average pumping rate of 2,138 gallons per minute, South Kingstown study site, southern Rhode Island. 


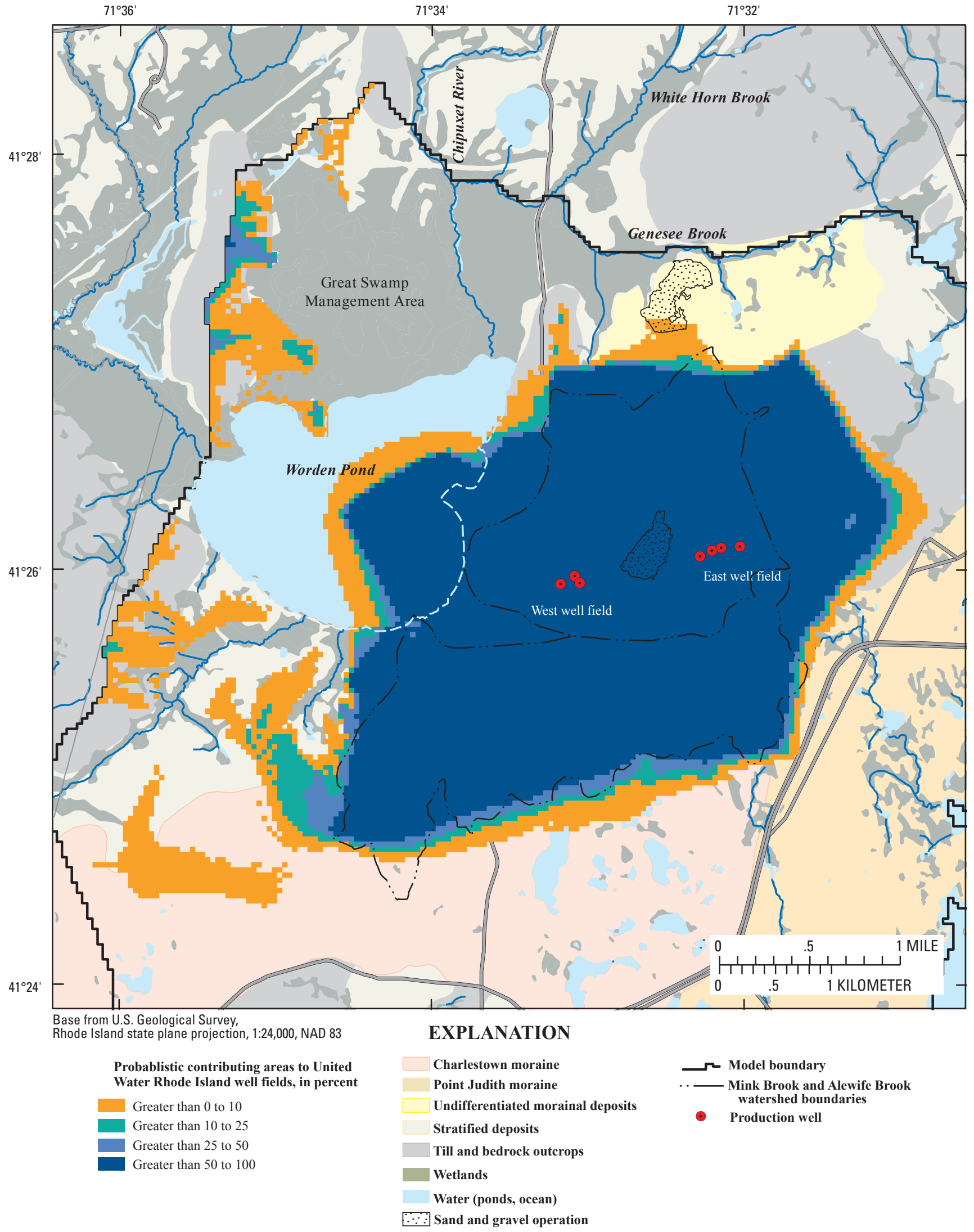

Figure 19. Simulated probabilistic areas contributing recharge to the United Water Rhode Island well fields at their total maximum pumping rate of 5,100 gallons per minute, South Kingstown study site, southern Rhode Island. 
hydraulic connection between Worden Pond and the aquifer, the simulated area contributing recharge at the maximum pumping rate expanded mostly north and south of the pond because of the groundwater divides near the well fields. Most of the till uplands northwest of Worden Pond and parts of the till uplands southwest of the pond are in the probabilistic contributing area. The deterministic contributing area in the till uplands northwest of Worden Pond corresponded to an area of high probabilities (greater than 50 percent) and probabilities of 39 to 48 percent. The probabilistic contributing area extended to the western edge of the model including areas between till uplands where assumed groundwater and surface-water divides may not coincide.

Additional water-level and streamflow observations and other types of field measurements may help reduce the uncertainty in the simulated contributing area by increasing the precision of the parameter value estimates and more accurately representing hydrologic features in the model. R_WETLD and KV_PEAT, two parameters specified in the model, had the least certainty of the parameters used in the Monte Carlo analysis. Detailed information on Worden Pond bed sediments, such as thickness and vertical hydraulic conductivity, would be important for the scenario that uses the maximum pumping rate. Additional streamflow observations in the Mink and Alewife watersheds and also distant from the production wells, such as the northward flowing streams to Worden Pond, may help decrease uncertainty of the predicted contributing area. 


\section{Charlestown Study Site}

The CBFD and EBWA well fields are on a peninsula or neck, called Quonochontaug Neck, a coastal setting in the Town of Charlestown, in southern Rhode Island (figs. 1 and 20). Quonochontaug Neck is bordered by Quonochontaug Pond and Ninigret Pond to the west and east, and by Block Island Sound to the south. To the north where Quonochontaug Neck is connected to the mainland, the Charlestown Moraine forms the watershed divide between the South Coastal watershed and the Pawcatuck River watershed. The geographic extent of the study area extended to surfacewater bodies, streams, a watershed divide in upland till, and presumed groundwater-flow paths that serve as boundaries for the numerical model. This model extent minimizes the effects of model boundaries on simulated heads near the area likely to be within the contributing area to the well fields. Land use on Quonochontaug Neck is primarily high-density residential, but it also includes developed recreation, wetlands, and forests.

The CBFD and EBWA well fields are each composed of two wells clustered near the center of Quonochontaug Neck; known characteristics of the production wells are listed in table 1. The drilled wells are completed near the top of the bedrock surface in a thin aquifer consisting of coarsegrained stratified deposits. Well depths range from about 22 to $28 \mathrm{ft}$ below land surface in about 20 to $25 \mathrm{ft}$ of saturated sediments. Areas contributing recharge were determined for both well fields at the average pumping rate during 2003-07 of $16 \mathrm{gal} / \mathrm{min}$ and for both well fields at the maximum pumping capacity of $230 \mathrm{gal} / \mathrm{min}$. Wastewater is disposed to groundwater through private septic systems.

Streamflow and peat thickness were measured in November and December 2006 to provide information concerning average streamflow conditions and wetland characteristics (fig. 20). Two sets of streamflow measurements were made at two sites in an unnamed tributary that drains the central part of Quonochontaug Neck near the well fields. Peat thickness was measured along two sections by manually probing the peat with a steel rod. Lithologic logs from USGS reports and files were compiled to define the bedrock surface and sediment size of the stratified deposits.

\section{Geology}

Sediments of glacial origin — stratified deposits, till, and morainal-overlie igneous and metamorphic bedrock (Moore, 1959) and fill generally southward sloping bedrock valleys (fig. 20). Deposits of the Charlestown Moraine thicker than $75 \mathrm{ft}$ overlie the bedrock in a main valley axis along the east boundary of the study area. Morainal deposits in the study area consist of till and stratified deposits of mostly sand and gravel sized sediment (Boothroyd, 2001). On Quonochontaug Neck, surficial deposits are generally 20 to $30 \mathrm{ft}$ thick, but bedrock outcrops are exposed, including southwest and northeast of the production well fields along the shoreline of Block Island
Sound and of Ninigret Pond (shown by $0 \mathrm{ft}$ contour lines in figure 20).

Stratified deposits south of the Charlestown Moraine were laid down by meltwater when the ice margin was at the moraine, and these deposits extended seaward into Glacial Lake Block Island (Boothroyd, 2001). A generalized northsouth section through Quonochontaug Neck (fig. 21) shows the lithology and thickness of surficial deposits and the vertical placement of PW1 of CBFD. The CBFD and EBWA well fields are screened in coarse-grained ice-proximal part of a morphosequence. These coarse-grained deposits consist of mostly sand and gravel but they also include boulders, which are exposed on the land surface and in the wetlands on Quonochontaug Neck.

Post-glacial deposits of peat, organic-rich pond-bottom sediments, and beach sand locally overlie glacial deposits. Manual probing of the wetlands near the well fields (fig. 20) indicated that peat thickness ranged from 1.2 to $4.8 \mathrm{ft}$; peat thickness generally ranged from 2 to $4 \mathrm{ft}$. Peat deposits most likely extend beneath West Pond southeast of the well fields. Parts of the large coastal ponds developed in large kettle depressions (Masterson and others, 2007). That part of Ninigret Pond within the study area is underlain by 3 to $5 \mathrm{ft}$ of fine-grained organic-rich sediments in the center areas and, in some cases, these sediments overlie former wetland deposits of peat (Dillion, 1970).

\section{Hydrology}

The geographic extent of the study area includes parts of the South Coastal watershed and Pawcatuck River watershed (fig. 20). The Charlestown Moraine, which forms a 120-ft ridge above the coast and $80 \mathrm{ft}$ above Watchaug Pond in the Pawcatuck River watershed, forms the surface-water divide between the two watersheds. A map of water-table contours by LaSala, Jr., and Johnson (1960) shows a groundwater divide in the moraine between these two watersheds, but there were no water-level data to support this location. The manually calibrated regional model (Masterson and others, 2007) simulated a groundwater divide through most of the moraine in the study area.

Quonochontaug Pond and Ninigret Pond, connected to Block Island Sound by breachways, are saltwater ponds. These coastal ponds are shallow with most of Ninigret Pond less than 6-ft deep (Dillion, 1970). Freshwater underlies these saltwater ponds and barrier beaches (Masterson and others, 2007). Small streams discharge mainly along the northern margins of the ponds. The average stage of the coastal ponds and locally of Block Island Sound relative to NGVD29 was not measured for this study.

On Quonochontaug Neck a small stream drains the central part of the neck and one of three small freshwater ponds (West Pond) and associated wetlands to Quonochontaug Pond. The stream network delineated at the 1:5,000 scale routes the stream through the wetland near the well fields, but 


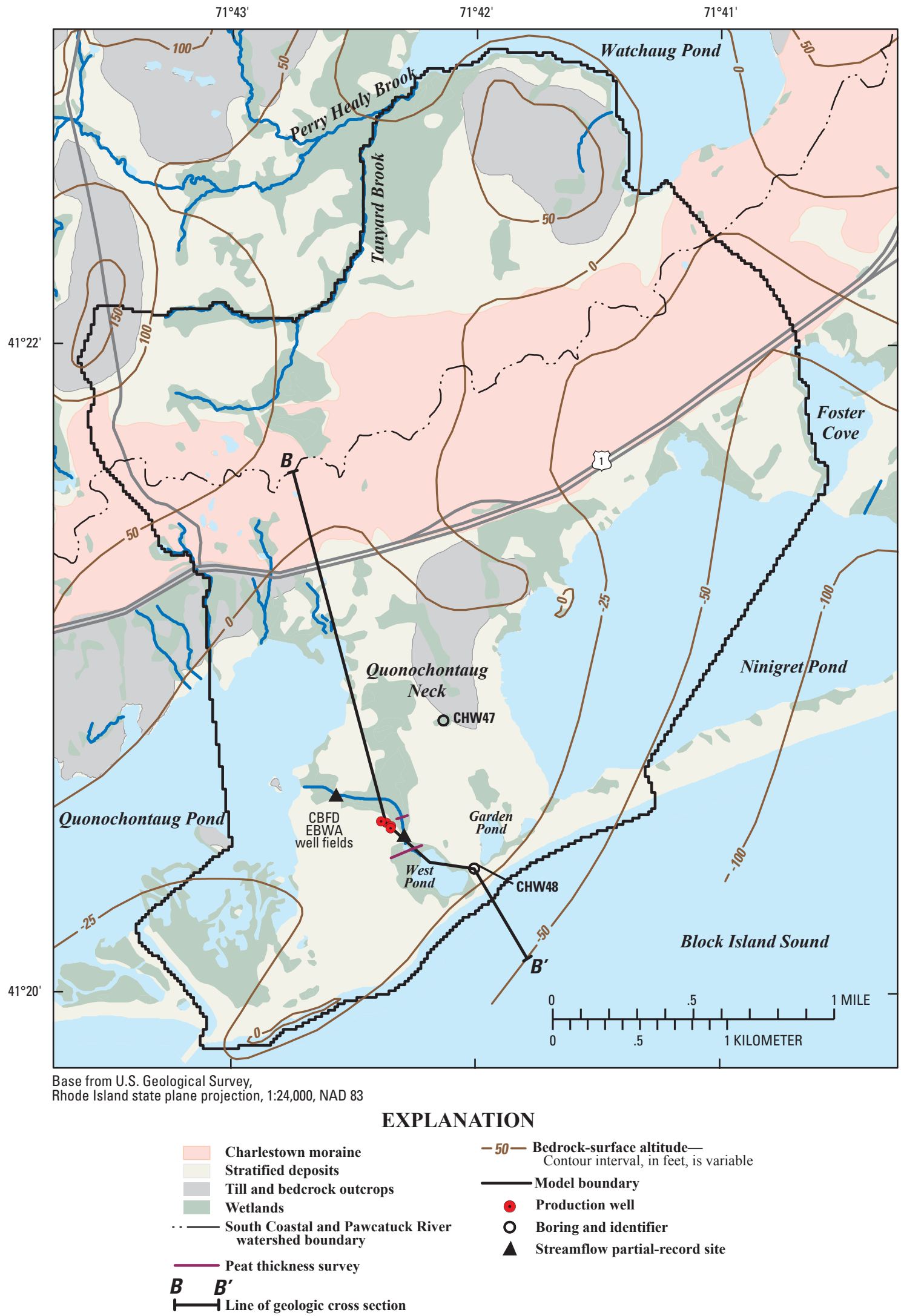

Figure 20. Production wells, section lines, selected borings, streamflow partial-record sites, model extent, bedrock-surface contours, and surficial geology, Charlestown study site, southern Rhode Island. 


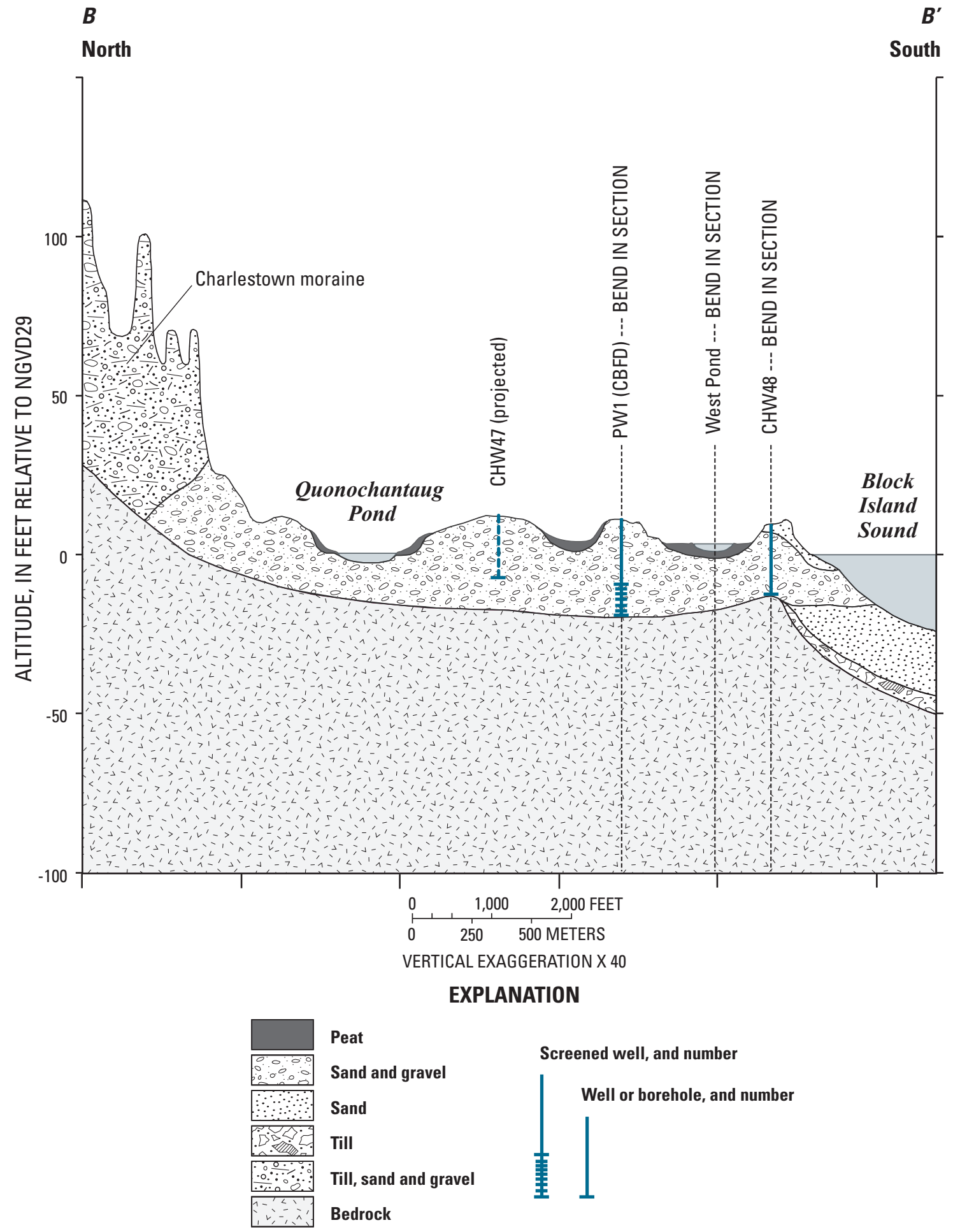

Figure 21. Geologic cross section, Charlestown study site, southern Rhode Island. 
field observations indicated no defined channel through most of the wetland. Two sets of streamflow measurements made at culverts upstream and downstream of the well fields and of this wetland (fig. 20) on November 7 and December 20, 2006, indicated a net gain of 0.02 and $0.16 \mathrm{ft}^{3} / \mathrm{s}$. Measurements were made near mean annual streamflow conditions (shown in figure 5 as at mean annual streamflow conditions for this long-term gage), but this assessment was based on multiple long-term streamgages with drainage areas more than an order of magnitude larger than the stream and wetland. The specific conductance of streamwater at both sites measured December 20, 2006, was $168 \mu \mathrm{S} / \mathrm{cm}$, typical of freshwater that is unaffected by saltwater. Groundwater levels measured in the southern half of Quonochontaug Neck by Urish $(1992,2000)$ indicated that seasonal water-level fluctuations in individual dug wells ranged from 0.8 to $4.2 \mathrm{ft}$, and they also indicated a groundwater mound southwest of the well fields.

The source of freshwater in the study area is precipitation. If there is about $29 \mathrm{in} / \mathrm{yr}$ available for recharge, based on average mean annual streamflow in southern Rhode Island (see Introduction heading Recharge Rates), then the total water available for recharge on Quonochontaug Neck $\left(0.85 \mathrm{mi}^{2}\right)$ is equivalent to $1.8 \mathrm{ft}^{3} / \mathrm{s}$ or $810 \mathrm{gal} / \mathrm{min}$. The total average well field withdrawal rate is 2 percent and the total maximum well field pumping rate is about 30 percent of the water available for recharge on the neck. This estimate of total water available for recharge, however, does not represent the amount of water that could be withdrawn from the neck because of potential saltwater intrusion, impacts to surfacewater bodies, and groundwater inflow from the mainland.

\section{Simulation of Groundwater Flow and Areas Contributing Recharge}

The groundwater-flow model for the Charlestown study site was designed to simulate long-term, steady-state groundwater levels, flow paths, and traveltimes. A model design similar to that used for the South Kingstown study site was used: two thin top layers to simulate surface-water features and associated bottom sediments, and a bottom layer to represent bedrock. One intervening layer represented most of the glacial deposits, which is where pumping withdrawals occur. Two intervening layers were used in the South Kingstown study site; however, the glacial deposits are thinner in the Charlestown study site. Simulation of the freshwatersaltwater interface was beyond the scope of the study. The model was calibrated to average annual pumping conditions for 2003-07 based on historical water-level observations and a streamflow observation made during this study. Deterministic areas contributing recharge to the well fields for different pumping rate scenarios were simulated, and an uncertainty analysis of the contributing area was performed. Wastewater return flow through private septic systems was not simulated in the model. Simulated contributing areas to the well fields, therefore, represent slightly larger, more conservative areas than if return flow had been included in the model.

\section{Model Extent and Spatial Discretization}

Groundwater flow in the study area was simulated by a four-layer finite-difference numerical model with a uniformly spaced grid. The model extended to natural hydrologic boundaries beyond the likely area contributing recharge to the well fields. Lateral model boundaries included large surface-water bodies near the well fields: Block Island Sound in the south and Quonochontaug and Ninigret Ponds directly west and east. In the northeast, the edge of the model extended to Foster Cove and Watchuag Pond, and it paralleled groundwater-flow paths between these two ponds based on a water-table map drawn by LaSala, Jr., and Johnson (1960). In the north, the edge of the model coincided with streams that drain to Watchaug Pond (Perry Healy Brook, Tanyard Brook, and an unnamed tributary). In the northwest, the model extended to a tributary that drains into Quonochontaug Pond and a watershed divide in upland till. The model boundary between this watershed divide and nearby streams was drawn along presumed groundwater-flow paths based on the water-table map by LaSala, Jr., and Johnson (1960). The groundwater-flow model subdivided the study area of $5.5 \mathrm{mi}^{2}$ into 312 rows and 173 columns and included a total of 169,880 active cells. Each cell was $60 \mathrm{ft}$ by $60 \mathrm{ft}$ square. The simulated area included both surficial deposits and bedrock.

All model layers were simulated by using a fixed transmissivity. The model initially represented surficial deposits in the top layer and bedrock in the bottom layer. The top of the model grid, which is used to determine transmissivity of the top layer, was first set to land-surface altitude. The top of the model grid was reset by running the initial model, temporarily adjusting hydraulic properties until the simulated water table compared favorably to available water levels and land-surface altitudes, and then the simulated water-table altitude was used as the top of the model. The top layer was then subdivided into three layers (layers 1 to 3) based on surface-water features, lithology, and placements of the production well screens. Layer 1 is $2 \mathrm{ft}$ thick to represent surface water in small ponds and wetlands. Layer 2 is $2 \mathrm{ft}$ thick to represent peat deposits beneath wetlands and small ponds, and $5 \mathrm{ft}$ thick to represent organic-rich coastal pond-bottom sediments. Layer 3 represented the remaining surficial deposits, which is the layer in which the production wells are screened. Stratified deposits, till, and the moraine are represented in all three layers. Shallow bedrock areas less than $5 \mathrm{ft}$ from the top of the model were incorporated into surrounding surficial materials. Layer 4 , the bottom layer, represented only bedrock. Bedrock was assigned a constant thickness of $200 \mathrm{ft}$ throughout the model beneath the surficial deposits. 


\section{Boundary Conditions and Model Parameters}

The interaction between streamflow and groundwater was simulated as a head-dependent flux boundary by using the stream-routing package (Prudic, 1989) developed for MODFLOW (fig. 22). The stream-routing package accounts for gains and losses of water in each stream cell, and it routes streamflow from upstream cells to downstream cells. The model contained 477 stream-routing cells. Stream altitudes were interpolated from topographical contours intersecting streams and from pond altitudes listed on the USGS Quonochontaug quadrangle. Both water depth and bed thickness were set equal to $1 \mathrm{ft}$ so that the top and bottom bed altitude could be determined from stream altitudes. Streams were simulated as $10 \mathrm{ft}$ wide. Streambeds were assumed to consist of coarse-grained sediments or organic-rich finegrained materials, such as the tributary near the well fields. For organic-rich streambeds, a vertical hydraulic conductivity of one-tenth the value of that for coarse-grained beds was used. A dimensionless parameter (SB_MULT) (table 4) was defined that multiplied the vertical hydraulic conductivity value. A dimensionless multiplier of 1 is equivalent to $1 \mathrm{ft} / \mathrm{d}$ for coarse-grained beds and $0.1 \mathrm{ft} / \mathrm{d}$ for organic-rich beds. A parameter value of 1 would also be equivalent to streambed conductances of $600 \mathrm{ft}^{2} / \mathrm{d}$ for coarse-grained beds and $60 \mathrm{ft}^{2} / \mathrm{d}$ for organic-rich beds.

A constant-head boundary was used to simulate large surface-water bodies-Block Island Sound and the coastal ponds - and the two smaller ponds that form part of the northeast edge of the model-Foster Cove and Watchaug Pond (fig. 22). The average stage of the large surface-water bodies is unknown; for this study a stage of $0 \mathrm{ft}$ NGVD29 was assumed. The stage of the two smaller ponds was determined from pond altitudes listed on the USGS Quonochontaug quadrangle. The model contained 9,352 constant-head cells.

Recharge parameters were distributed based on surficial geology and surface-water features (table 4). Recharge values used in the model are effective rates, which account for groundwater evapotranspiration. A single recharge parameter represented the stratified deposits and the morainal deposits (R_SDM); conceptually, recharge rates should be similar for both surficial materials because the morainal deposits consist of mostly permeable materials. A second recharge parameter was defined for upland till (R_TILL). Any surface runoff from till hillslopes that may recharge permeable stratified and morainal deposits at the upland-valley contact was not included in model simulations. A recharge parameter was defined for the wetlands (R_WETLD), and it represented water available for recharge. Some or all of this water may infiltrate, particularly under pumping conditions, or it may move across the surface as overland flow. R_WETLD was therefore set at a fixed value for model calibration, but the uncertainty in the specified value was included in the probabilistic contributing area analysis. Pond recharge was specified for all model simulations. The same value of $22 \mathrm{in} / \mathrm{yr}$ was applied to pond water and wetland areas by subtracting the evaporation rate from a free-water surface ( $29 \mathrm{in} / \mathrm{yr})$ (Farnsworth and others, 1982) from the rate of precipitation for southern Rhode Island (51 in/yr).

Hydraulic conductivity parameters were assigned on the basis of lithology (table 4). Horizontal hydraulic conductivity of the stratified deposits was represented by parameter K_SD, till by parameter K_TILL, and morainal deposits by parameter K_MOR. Horizontal hydraulic conductivity of bedrock was represented by parameter K_ROCK and wetlands by parameter K_WETLD. Parameter K_WETLD represented overland flow in the wetlands and groundwater flow through any large interconnected pores in poorly decomposed upper part of the peat. Model cells containing small freshwater ponds were assigned a hydraulic conductivity value of $50,000 \mathrm{ft} / \mathrm{d}$ to simulate minimal resistance to flow and the corresponding flat gradient across these water bodies.

The ratio of horizontal hydraulic conductivity to vertical hydraulic conductivity for stratified deposits, morainal deposits, and till was represented by parameters KV_SD, KV_MOR, and KV_TILL, respectively. The ratio of horizontal to vertical hydraulic conductivity for bedrock was defined by parameter KV_ROCK and for peat by parameter KV_PEAT. The horizontal hydraulic conductivity for peat was held constant in the model at $1 \mathrm{ft} / \mathrm{d}$; the ratio is, therefore, always in relation to this value. KV_PEAT represented the medium decomposed and highly decomposed peat at depth that controls the connection between the wetland and the underlying aquifer.

\section{Observations}

The groundwater-flow model was calibrated to 46 waterlevel observations and 1 streamflow observation. Observations were weighted based on methods described by Hill and Tiedeman (2007); the weights account for measurement error and for the difference in units as between water levels and streamflows. Water-level observations were divided into Groups A and B on the basis of their estimated accuracy (fig. 22). Group A included 20 groundwater levels and 1 pond level measured July 1990 and October 1999 by Urish (1992, 2000). Water levels measured July 1990 were near average annual groundwater conditions based on USGS long-term observation well CHW18 (fig. 6). October 1999 water levels were made at below-average groundwater conditions (fig. 6); however, considerable precipitation fell in the second half of September 1999. A comparison of available water levels measured in the same wells in both years indicated that most water levels during October 1999 were within 0.4 to $0.6 \mathrm{ft}$, both above and below the July 1990 water levels. Because depth to the water table in Quonochontaug Neck is less than depth at CHW18 (about $8 \mathrm{ft}$ compared to $18 \mathrm{ft}$ ), water levels in Quonochontaug Neck may respond more quickly to precipitation recharge or there may have been less of a soil moisture deficit. Datum for Group A observations was local approximate mean sea level determined by tide-survey measurements in Quonochontaug Pond (Urish 1992, 2000). 


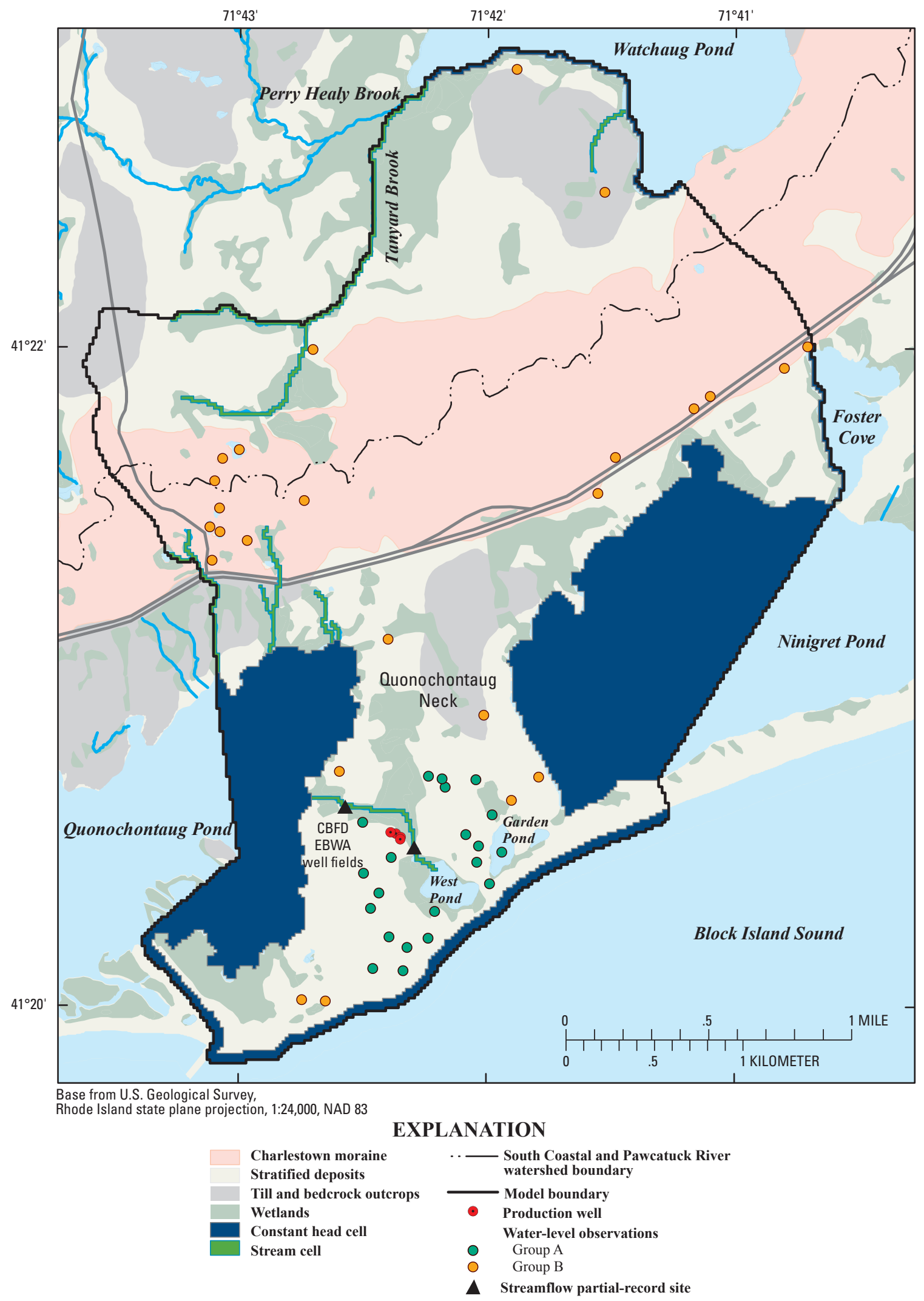

Figure 22. Model-boundary types and observations, Charlestown study site, southern Rhode Island. 


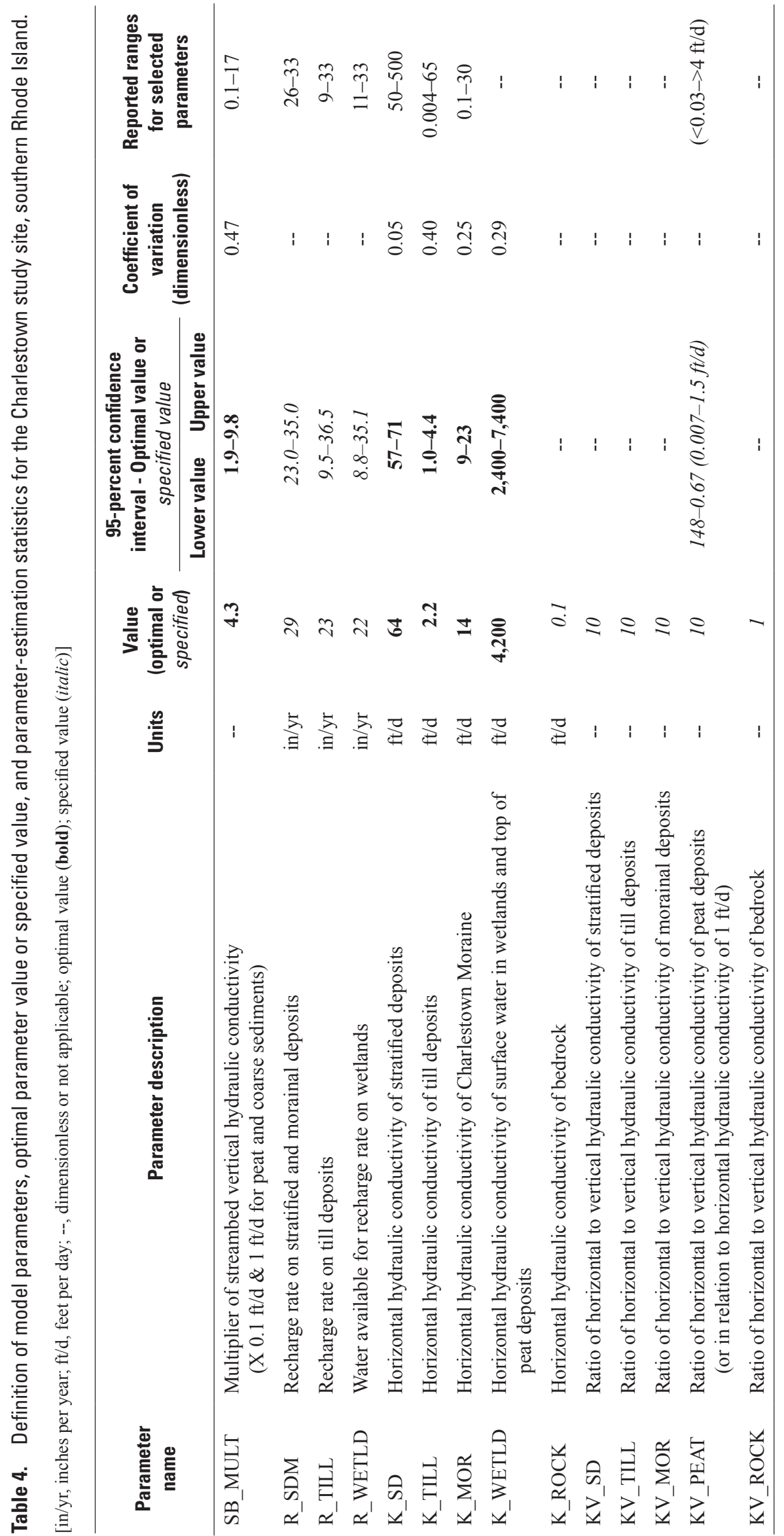


Accuracy of the observations was estimated at $0.5 \mathrm{ft}$ because the accuracy of the survey was not reported and the accuracy of the local datum and its relation to NGVD29 was unknown. Group A observations are distributed in the southern half of Quonochontaug Neck and are included in layer 1 because they were measured in shallow dug wells.

Group B included 17 groundwater levels measured primarily during August and September 1955 (LaSala, Jr., and Hahn, 1960; LaSala, Jr., and Johnson, 1960) also near average annual groundwater conditions (fig. 6). Accuracy of Group B groundwater levels, whose measuring-point altitudes were based on land-surface altitudes determined from the USGS Quonochontaug and Carolina quadrangles, is about $5 \mathrm{ft}$ (U.S. Geological Survey, 1980). These groundwater levels were distributed throughout the modeled area, except for the center areas of the moraine. Because most of these water levels were measured in shallow dug wells they were included in layer 1 . In addition to groundwater levels, Group B included 8 pond altitudes determined from land-surface contours on the USGS Quonochontaug quadrangle, all located in the Charlestown Moraine. These ponds are assumed to be in good hydraulic connection with the surrounding aquifer. Accuracy of these pond altitudes was also assumed to be $5 \mathrm{ft}$.
A streamflow observation represented the average net gain $\left(0.09 \mathrm{ft}^{3} / \mathrm{s}\right)$ of surface flow through the wetland near the well fields based on the November and December 2006 streamflow measurements. The accuracy of each streamflow measurement was about 10 percent. Because the streamflow gain was determined from an upstream and a downstream measurement, the variance of the errors of the two streamflow measurements was summed.

\section{Estimation of Parameters}

Model parameters included three for recharge, five for horizontal hydraulic conductivity, five for vertical anisotropy, and one for streambed hydraulic conductivity (table 4).

Parameter R_WETLD, which represented water available for recharge in the wetlands, was specified in the model, but the uncertainty in the parameter value was included in the probabilistic contributing area analysis.

Composite scaled sensitivities indicated that the waterlevel observations and the streamflow observation provided insufficient information to estimate all parameters (fig. 23). The parameters for vertical anisotropy had low parameter sensitivities and thus were assigned values from the literature.

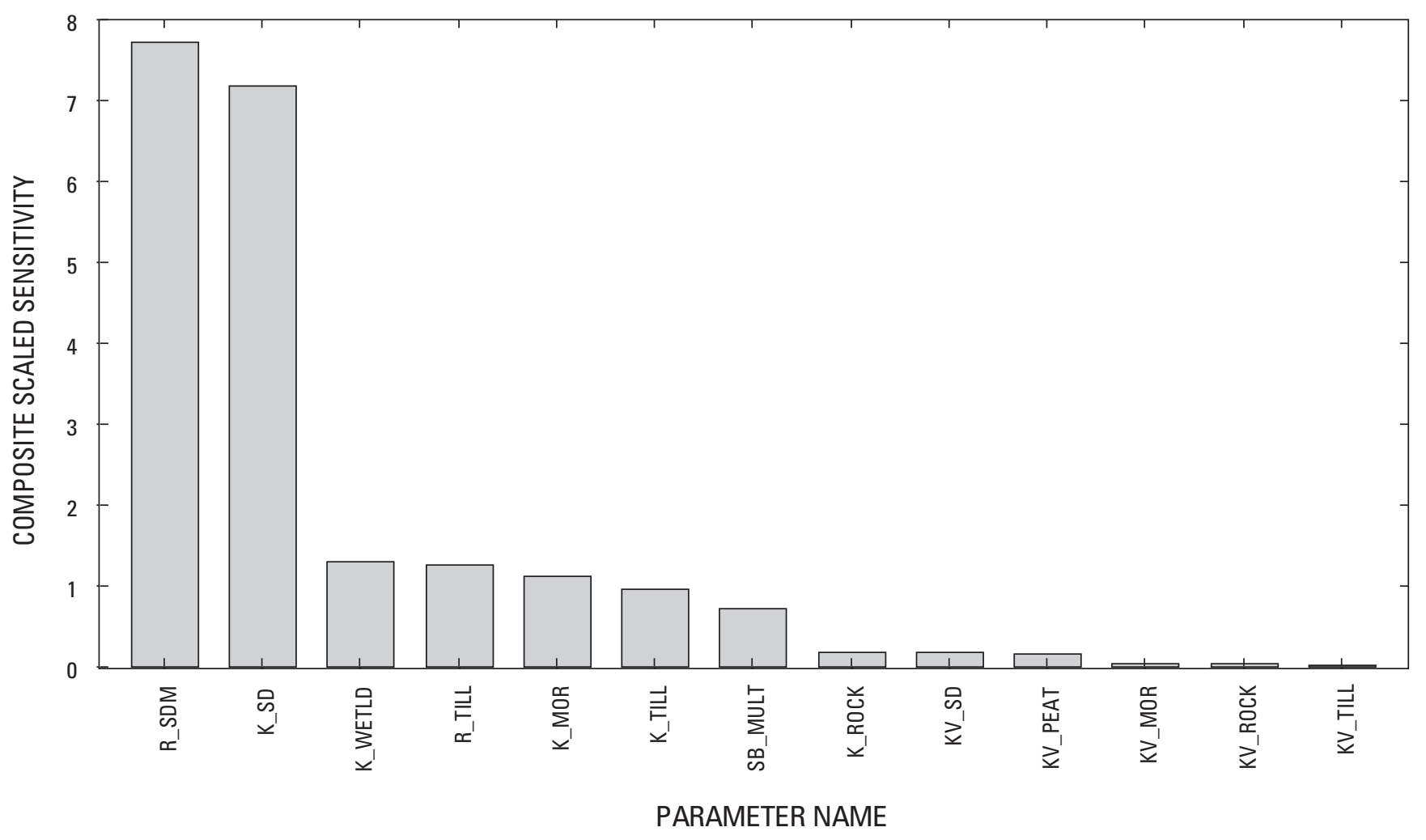

Figure 23. Composite scaled sensitivities for model parameters (parameter information is provided on table 4), Charlestown study site, southern Rhode Island. 
The ratios of horizontal to vertical hydraulic conductivity of glacial deposits (KV_SD, KV_TILL, KV_MOR) and of peat (KV_PEAT) were set to 10; because the horizontal hydraulic conductivity of peat was set to $1 \mathrm{ft} / \mathrm{d}$, the resulting vertical hydraulic conductivity was equivalent to $0.1 \mathrm{ft} / \mathrm{d}$. KV_ROCK was specified a ratio of 1 . In addition to vertical anisotropies, the parameter for horizontal hydraulic conductivity, K_ROCK, had a low sensitivity and was set to $0.1 \mathrm{ft} / \mathrm{d}$.

Several of the parameters with high parameter sensitivities were highly correlated to each other and thus not all of the remaining parameters could be estimated uniquely. R_SDM and K_SD had a parameter correlation of 0.99, and R_TILL and K_TILL had a parameter correlation of 0.98 . Values for both recharge parameters were specified for model calibration. R SDM was assigned a value of $29 \mathrm{in} / \mathrm{yr}$, which is the mean and median long-term annual runoff rate for streamgages in southern Rhode Island and the recharge rate determined from model calibration for the South Kingstown study site. R_Till was assigned a value of $23 \mathrm{in} / \mathrm{yr}$, also determined from model calibration for the South Kingstown study site and within the reported range of recharge rates determined for till-dominated watersheds by computerized hydrograph-separation methods. The remaining five parameters representing hydraulic properties, K_SD, K_ TILL, K_MOR, K_WETLD, and SB_MULT, were estimated by nonlinear regression.

The quality of model calibration can be determined through analysis of the weighted residuals, both numerically and graphically (Hill and Tiedeman, 2007). Weighted residuals should be randomly distributed and close to zero. The average weighted residual was $0.02 \mathrm{ft}$ and ranged from a minimum of $-3.6 \mathrm{ft}$ to a maximum of $4.8 \mathrm{ft}$. The sum of squared weighted residuals was 127 for the calibrated model. The calculated error variance and the standard error of the regression, measures of the overall magnitude of the weighted residuals, were 3.03 and 1.74, respectively. A comparison of weighted residuals, shown in figure $24 \mathrm{~A}$, indicated that residuals are generally randomly distributed around zero for all weighted simulated values. Forty-five of the 47 observations are within two standard errors of the regression. A comparison of weighted observed values and weighted simulated values (fig. 24B) indicated a reasonable agreement; the correlation between weighted observed values and weighted simulated values was 0.98 . The spatial distribution of weighted water level and streamflow residuals (fig. 25) is generally distributed randomly throughout the modeled area except near the contact between the morainal and stratified deposits north of Ninigret Pond. In this modeled area, simulated water levels are greater than observed water levels for five of the six observations.

Observations with the most overall influence in the set of estimated parameter values were determined from Cook's D statistics. Three water-level observations and the streamflow observation had a Cook's D value greater than the critical value of 0.085 ( 4 divided by number of observations). The observations with the most overall influence in the parameter estimation (fig. 25) are distributed throughout the model. The streamflow observation, in addition to being an influential observation to the set of estimated parameters, was the only observation important to more than two individual estimated parameters, according to DFBeta statistics.

Optimal values for the five hydraulic parameters that were estimated using nonlinear regression are listed in table 4. The optimal values for the glacial deposits and the streambed multiplier are within the range of values reported in the literature as discussed in the "Hydraulic Properties" section. The optimal value for horizontal hydraulic conductivity of wetlands (K WETLD) was in the mid-range of values (1,000-10,000 ft/d) determined by manual calibration for wetlands in southern Rhode Island by Masterson and others (2007). The optimal value for K_SD was at the low end of expected values for coarse-grained stratified deposits. These deposits were laid down near the ice margin and may not be well-sorted or the bedrock surface may need to be more accurately defined. The optimal value for K_MOR $(14 \mathrm{ft} / \mathrm{d})$ is close to the simulated value for Charlestown morainal deposits in the South Kingstown study site $(16 \mathrm{ft} / \mathrm{d})$. The dimensionless multiplier of streambed vertical hydraulic conductivity, STR_MULT, is equivalent to $4.3 \mathrm{ft} / \mathrm{d}$ for coarse-grained bed sediments and to $0.43 \mathrm{ft} / \mathrm{d}$ for organic-rich bed sediments.

The precision or uncertainty of the parameter estimate is indicated by the 95-percent linear confidence interval for each optimal value (table 4). For these linear confidence intervals to be valid, weighted residuals should be normally distributed and the model linear near the estimated optimal values (Hill and Tiedeman, 2007). The correlation between weighted residuals and the normal order statistics for the calibrated model was 0.984 . This value is greater than the critical value for 47 observations, 0.951, at the 5-percent significance level, which indicates that the weighted residuals are independent and normally distributed. The degree of model linearity can be quantified using the modified Beale's measure. The model is considered effectively linear if the modified Beale's measure is less than 0.037 and nonlinear if it is greater than 0.41 . The modified Beale's measure for the model was 0.034 , indicating that the model is linear; thus, the linear confidence intervals are considered to be accurate.

The 95-percent confidence intervals for the parameter estimates are within the range of reasonable values reported in the literature. A comparison of the relative precision of different parameter estimates can be made using the coefficient of variation (standard deviation of the estimate divided by the optimal value) (table 4); a smaller coefficient of variance indicates a more precise parameter estimate. The covariance of variation ranged from 0.05 for K_SD to 0.47 for SB_MULT. Of the remaining parameters, K_MOR and K_WETLD were more precisely estimated than K_TILL. The order of the most to the least precisely estimated parameter values generally follows the same order as that of the parameter sensitivities (fig. 23) because of the information provided by the observations in the regression. 

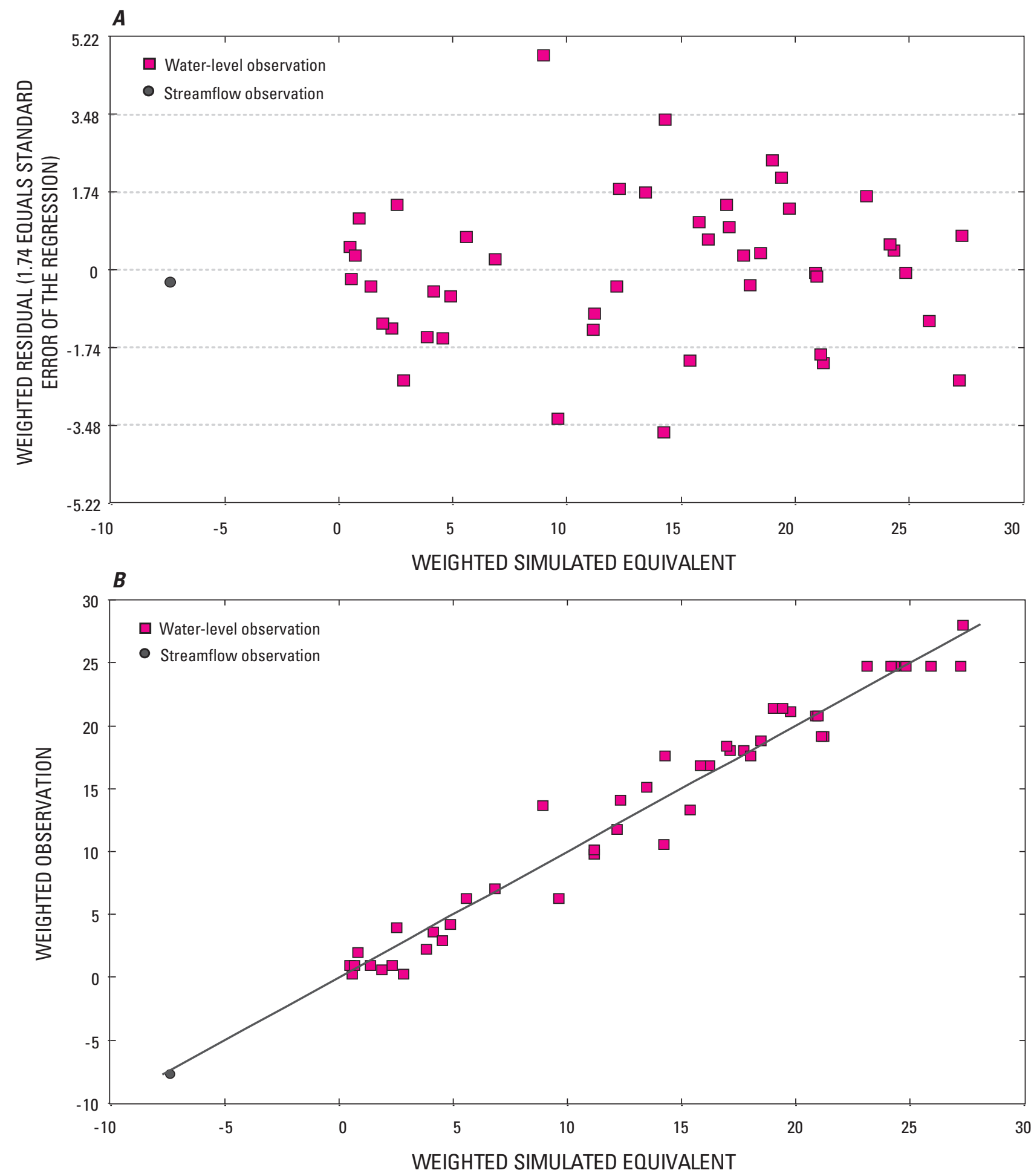

Figure 24. Relation of $A$, weighted residual to weighted simulated equivalent, and of $B$, weighted observation to weighted simulated equivalent, Charlestown study site, southern Rhode Island. 


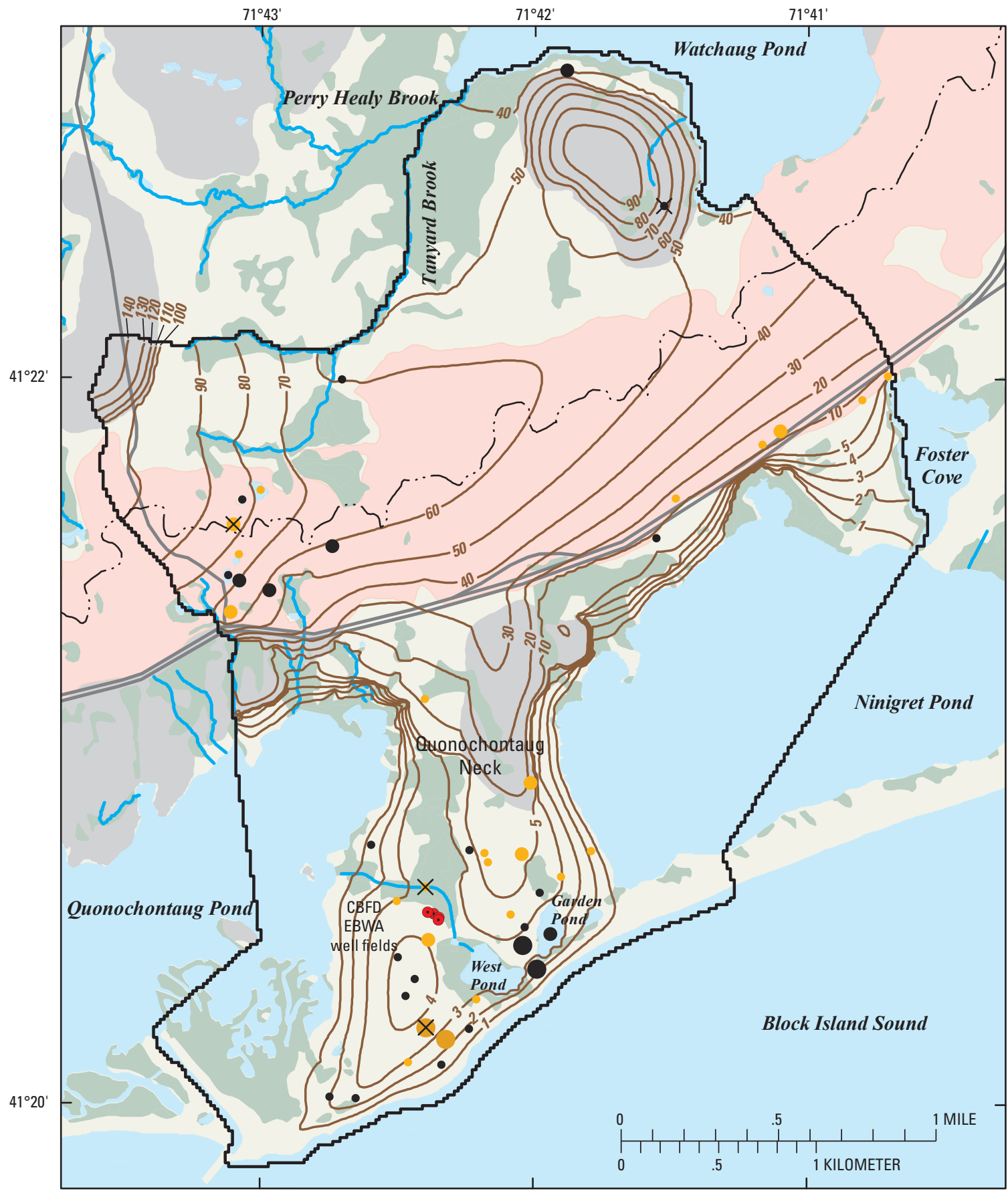

Base from U.S. Geological Survey,

Rhode Island state plane projection, 1:24,000, NAD 83

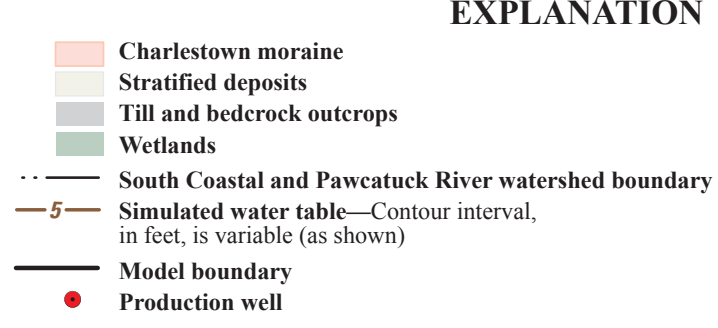

Weighted residual
less than -3
-3 to -1.5
-1.5 to 0
0 to 1.5
1.5 to 3
greater than 3
Cook's $D$ greater than critical value

Figure 25. Spatial distribution of weighted residuals and simulated water-table contours for calibrated, steadystate conditions, Charlestown study site, southern Rhode Island. 


\section{Simulated Water-Table Contours and Water Budget}

The altitude and configuration of the simulated water table for the calibrated model are shown in figure 25 at 10 -ft contour intervals except for 1 -ft intervals in low-lying areas of Quonochontaug Neck and near the coastal ponds. The simulated water-table contours and flow patterns are consistent with the conceptual model of groundwater flow in the study area and with groundwater maps by LaSala, Jr., and Hahn (1960), LaSala, Jr., and Johnson (1960), and Urish (2000). Groundwater generally flows from topographically high areas and discharges to streams and surface-water bodies. A simulated groundwater divide between South Coastal and Pawcatuck River watersheds is in the north part of the Charlestown Moraine near, but generally north, of the watershed divide. A simulated groundwater divide on Quonochontaug Neck trends north-south near the center of the neck from the till deposits toward West Pond and Garden Pond. Groundwater generally enters the three freshwater ponds along the northern perimeters, and pond water enters the aquifer along the southern perimeter before discharging to Block Island Sound. Water in West Pond also exits through the small stream but toward the northwest. Southwest of the well fields, a groundwater mound is simulated in the center of the area bounded by Block Island Sound, Quonochontaug Pond, and West Pond.

The simulated groundwater budget for the calibrated model indicated that recharge from direct precipitation provided $8.6 \mathrm{ft}^{3} / \mathrm{s}$ or 92 percent of the inflow. Stream leakage $\left(0.7 \mathrm{ft}^{3} / \mathrm{s}\right.$ or 7 percent $)$ and pond leakage $\left(0.1 \mathrm{ft}^{3} / \mathrm{s}\right.$ or 1 percent $)$ account for the remaining inflow. Most of the inflow, $6.6 \mathrm{ft}^{3} / \mathrm{s}$ or 70 percent, discharges to streams and to the large surfacewater bodies in the South Coastal watershed; the production well fields withdraw about $0.04 \mathrm{ft}^{3} / \mathrm{s}$. The remaining outflow, $2.8 \mathrm{ft}^{3} / \mathrm{s}$ or 30 percent, discharges to streams and Watchaug Pond along the northern model boundary.

\section{Deterministic Areas Contributing Recharge}

Simulated deterministic areas contributing recharge and groundwater traveltimes to the CBFD and EBWA well fields were determined on the basis of the calibrated steady-state model, for simulated pumping conditions, and tracking of pathlines with the MODPATH particle-tracking program. The areas contributing recharge to the well fields are based on both well fields pumping simultaneously. The areas contributing recharge would change if one of the well fields were to stop pumping or if withdrawal rates changed. The locations and extents of the simulated areas contributing recharge to each well field pumping at the 2003-07 average annual rate $(16 \mathrm{gal} / \mathrm{min})$ and the maximum rate $(230 \mathrm{gal} / \mathrm{min})$ are illustrated in figures 26 and 27.
The area contributing recharge for the average pumping rate is $0.018 \mathrm{mi}^{2}$. The area contributing recharge extends southwestward from the well fields to the simulated watertable mound, underlies a small part of the adjoining wetland, and includes isolated areas on the opposite side of the wetland northeast of the well fields. At the maximum withdrawal rate, the area contributing recharge $\left(0.26 \mathrm{mi}^{2}\right)$ expands in all directions to capture enough water to balance the increased pumping rate. At the lower pumping rate, the well fields mostly intercept groundwater that would have discharged to the adjoining wetland (or the stream routed through the wetland), but at the higher pumping rate, the well fields also intercept water that would have discharged directly to the coastal ponds and Block Island Sound. The area contributing recharge for the CBFD well field includes water originating in the till northeast of the well fields. The area contributing recharge for the EBWA well field includes an area underlying West Pond. As was mentioned previously, simulation of the freshwater-saltwater interface was beyond the scope of the study; however, model results indicated no infiltration from the saltwater bodies into the underlying aquifer at the maximum pumping rates.

Simulated traveltime estimates from recharging locations to the production wells for the maximum pumping rate are shown in figure 28. Estimated traveltimes are based on porosities of 0.35 for stratified deposits, till, and morainal deposits; 0.80 for peat deposits; 0.02 for bedrock; and 1 for surface water. Estimated traveltimes ranged from less than 6 months to more than 50 years; 94 percent of the traveltimes were 10 years or less. The median traveltime to the well fields in this thin aquifer was 1.3 years. Water that recharges the aquifer near the well fields has the shortest traveltimes, whereas water originating in the till northeast of the well fields and in the stratified deposits along the southwest edge of the contributing area has the longest traveltimes.

A limitation of using a fixed transmissivity for all model layers, previously mentioned in the section "Numerical Modeling" is that the simulated transmissivity of the aquifer near the well fields does not decrease with increased drawdowns that the maximum pumping rates cause. In the vicinity of the well fields, the simulated saturated thickness for the pumping rate used in the calibrated model and the maximum pumping rate decreased from $23 \mathrm{ft}$ to $15 \mathrm{ft}$. Traveltimes and areas contributing recharge to the well fields may be different for a model that uses fixed transmissivity when compared to a model that uses a variable transmissivity. If a variable transmissivity model had drawdowns similar to those of the fixed transmissivity model, then using a horizontal hydraulic conductivity value of $100 \mathrm{ft} / \mathrm{d}$ would have a transmissivity equivalent to that of the fixed transmissivity model. Although this hydraulic conductivity value is greater than the upper 95-percent confidence limit estimated by parameter estimation, it is within the range of reported values for coarse-grained deposits in Rhode Island. 


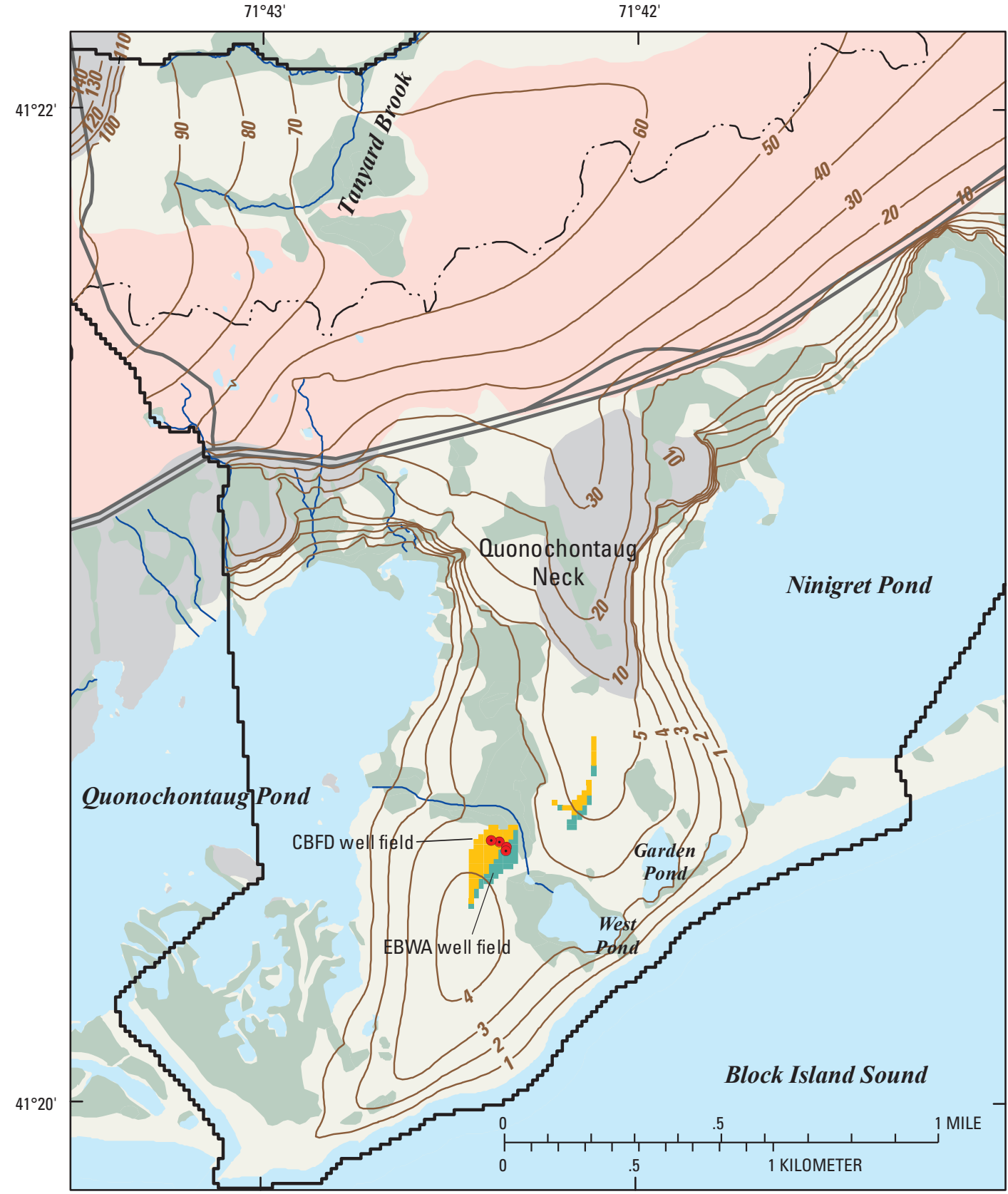

Base from U.S. Geological Survey,

Rhode Island state plane projection, 1:24,000, NAD 83

\section{EXPLANATION}
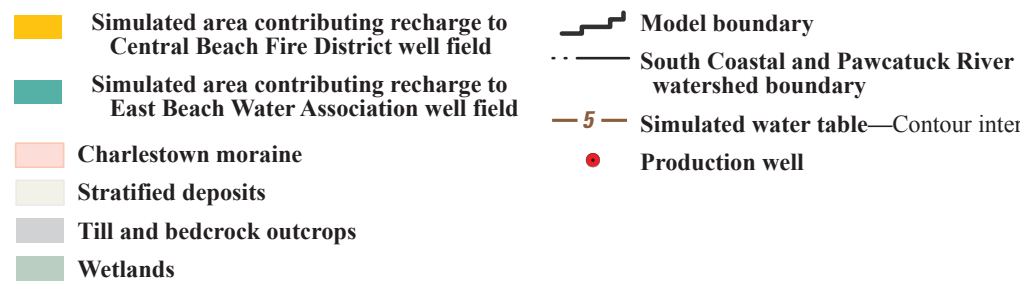

Wetlands

Figure 26. Simulated areas contributing recharge to the Central Beach Fire District and East Beach Water Association well fields, at their total average pumping rate of 16 gallons per minute, Charlestown study site, southern Rhode Island. 


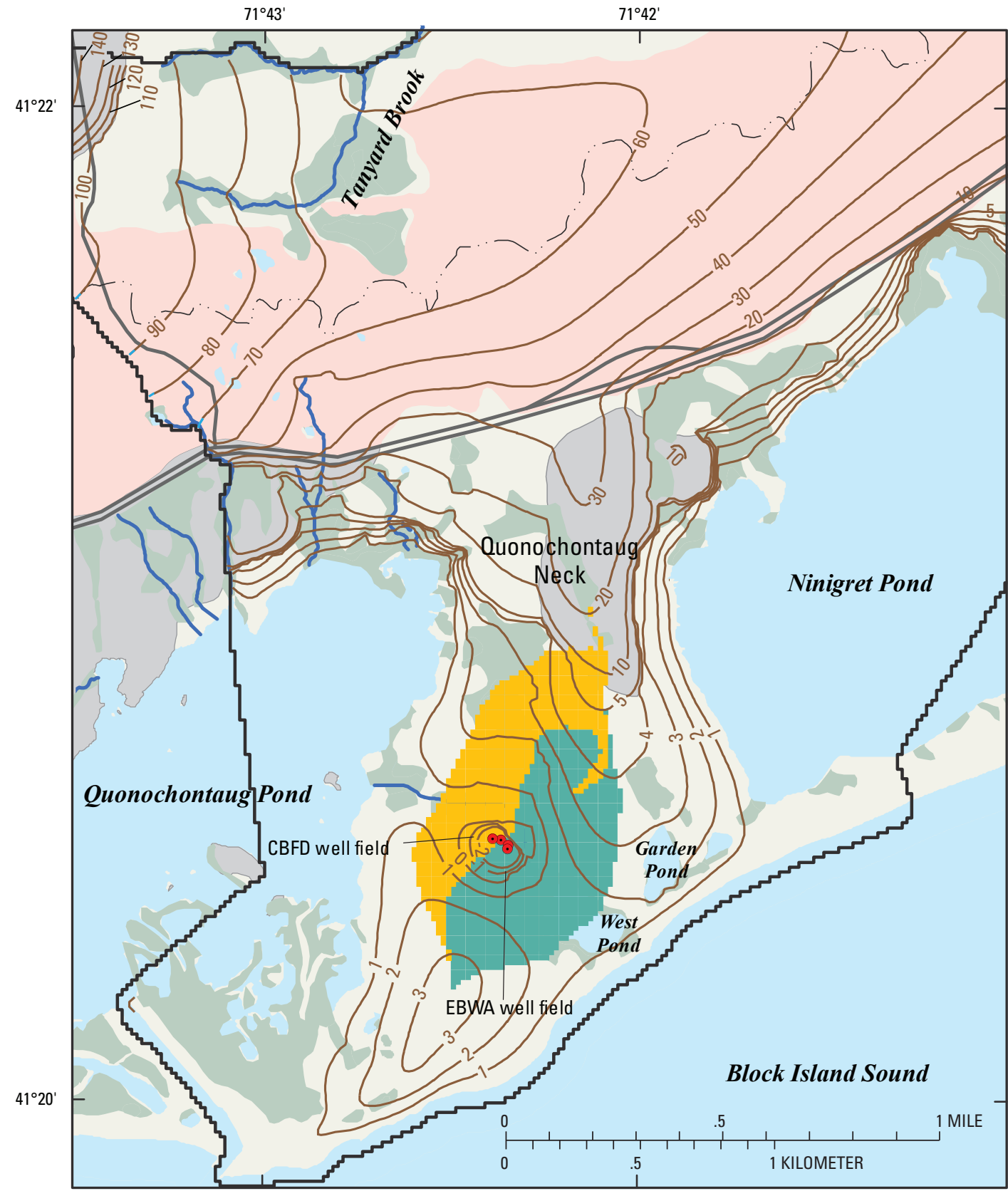

Base from U.S. Geological Survey,

Rhode Island state plane projection, 1:24,000, NAD 83

\section{EXPLANATION}

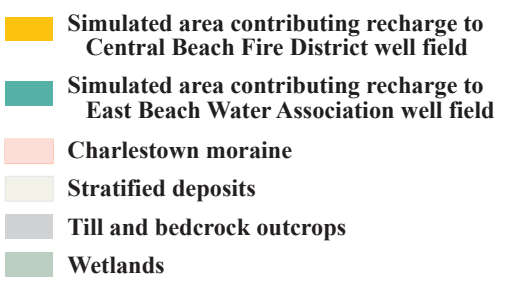
Model boundary
South Coastal and Pawcatuck River watershed boundary

$-5-$ Simulated water table - Contour interval is variable

- Production well

Figure 27. Simulated areas contributing recharge to the Central Beach Fire District and East Beach Water Association well fields, at their total maximum pumping rate of 230 gallons per minute, Charlestown study site, southern Rhode Island. 


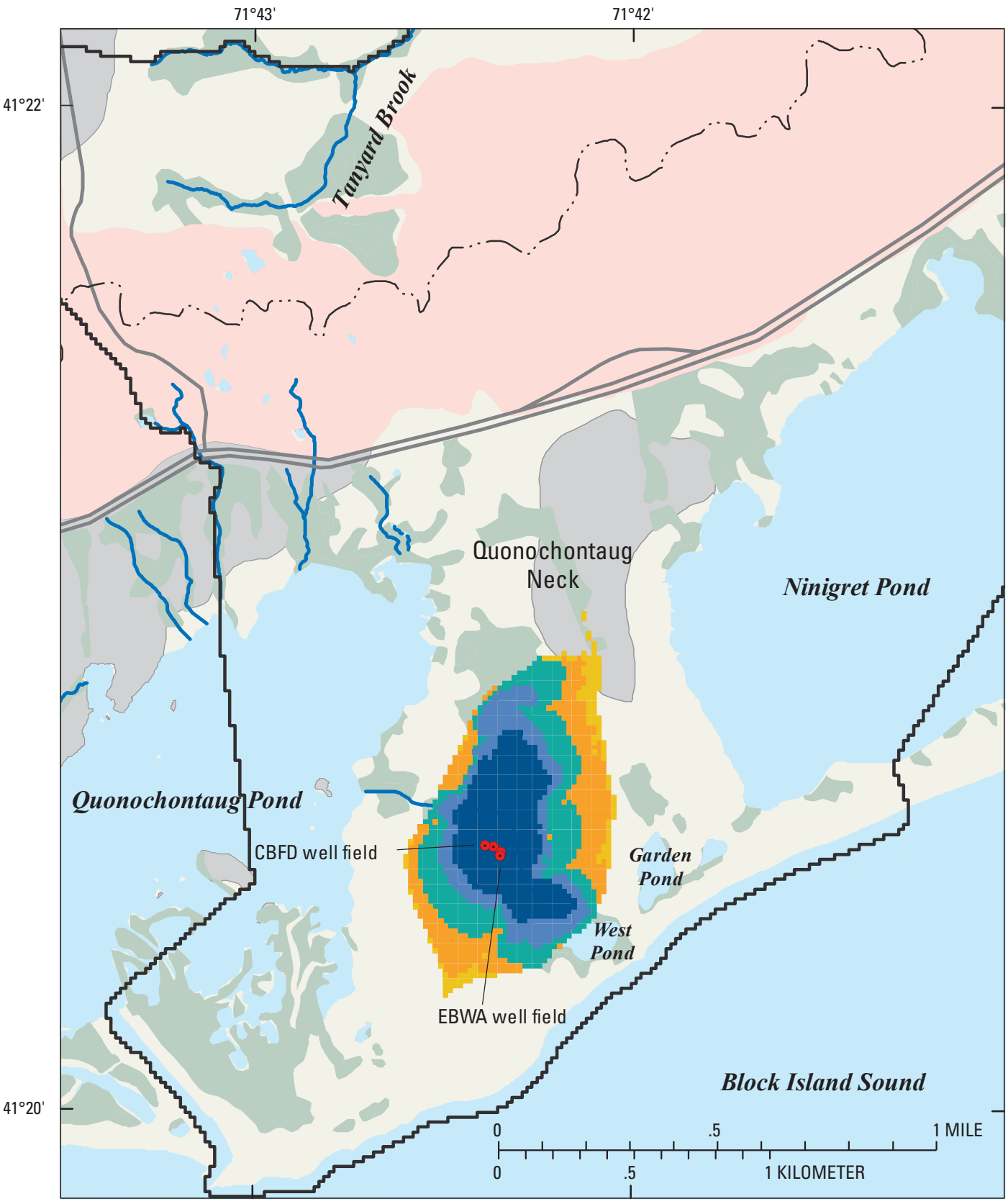

Base from U.S. Geological Survey,

Rhode Island state plane projection, 1:24,000, NAD 83

\section{EXPLANATION}
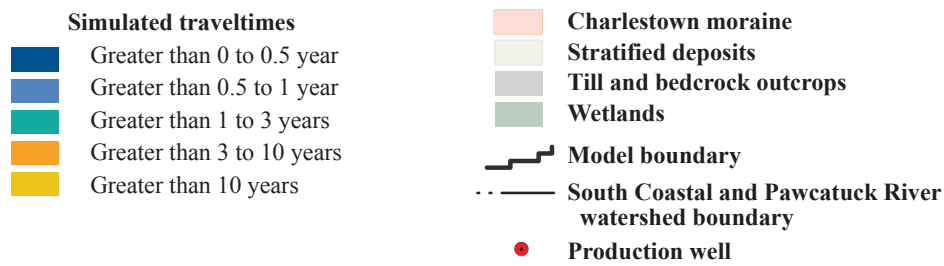

Figure 28. Simulated traveltimes to the Central Beach Fire District and East Beach Water Association well fields at their maximum pumping rate of 230 gallons per minute, Charlestown study site, southern Rhode Island. 


\section{Probabilistic Areas Contributing Recharge}

The deterministic areas contributing recharge were based on the optimal parameter set determined from nonlinear regression and specified parameter values from the literature. Information on model parameters is provided in table 4. Different degrees of precision are associated with these estimated parameter values. A quantitative measure of the effects of parameter uncertainty on the simulated contributing area was determined by a Monte Carlo analysis. The parameter variance-covariance matrix from nonlinear regression can be used to create plausible parameter sets for the Monte Carlo analysis (Starn and others, 2000). The variance-covariance matrix incorporates the uncertainty of the parameter estimates and the correlation among parameters from the calibrated model. Parameter values for the Monte Carlo analysis were generated by equation 1 .

In addition to the optimal parameter set estimated by nonlinear regression, several of the specified parameters were incorporated into the variance-covariance matrix. Uncertainty in the specified parameter values may also affect model predictions. A partial sensitivity analysis determined that unestimated parameters representing the anisotropy of glacial deposits and hydraulic properties of bedrock had little or no effect on the simulated contributing area to the production wells for a plausible range in values. Recharge parameters (R_SDM, R_TILL, and R_WETLD) and the hydraulic connection between surface water and the aquifer (KV_PEAT), important parameters that may affect the simulated contributing area in glacial valley-fill settings, were incorporated into the variance-covariance matrix. Incorporating these four parameters into the variancecovariance matrix, however, caused large unrealistic uncertainties about the specified parameter values, most likely because of insufficient information provided by the observations and high parameter correlations. Prior information for these parameters (see sections "Hydraulic Properties" and "Recharge Rates") was used to constrain uncertainty about the specified value to realistic ranges reported in the literature. Prior weights were used so that the 95-percent confidence intervals about the specified value (table 4) were equivalent to \pm 21 percent for R_SDM and to \pm 59 percent for R_TILL and R_WETLD. The 95-percent confidence interval for KV_PEAT was equivalent to a vertical conductivity for peat of 0.007 to $1.5 \mathrm{ft} / \mathrm{d}$. Thus, all parameter uncertainty important for model prediction was incorporated into the Monte Carlo analysis. In contrast with the South Kingstown study site, however, parameter uncertainty was constrained by observations as well as by prior information.

The parameter sets created by equation 1 for the Monte Carlo analysis are shown in figure 29A for hydraulic parameters and figure 29B for recharge parameters. The hydraulic parameters were log-transformed in the model. The parameter sets have a lognormal or normal distribution around the optimal or specified parameter value. The spread of these data indicates the certainty with which the parameter was estimated considering the observations and prior information. Parameter sets with a KV_PEAT value two orders of magnitude greater or less than the specified value of 10 (a vertical conductivity for of $0.1 \mathrm{ft} / \mathrm{d}$ ) were considered unrealistic for the vertical thickness of the peat layer simulated in the model, and thus parameter sets having these values were removed from the analysis. This accounted for 13 percent of the parameter sets.

For the Monte Carlo analysis, the model was first run with 1,000 parameter sets and the average pumping rate. The nine hydraulic and recharge parameter values in each set replaced corresponding parameter values in the calibrated model. Three acceptance criteria were used: (1) model had to converge, (2) model mass balance was 0.5 percent or less, and (3) calculated error variance was less than a specified value. The third acceptance criterion was varied in order to evaluate model fit to observations. These criteria were used so that model prediction uncertainty would not be overestimated. Results of the Monte Carlo analysis for the average pumping rate, with increasing calculated error variances, are summarized in table 5. The total size of the probabilistic contributing area was about the same (673 to 677 particles) for calculated error variances from 12 to 18 , but the size increased substantially (677 to 725 particles) if the model-fit statistic was not used. For this application of the Monte Carlo analysis, a calculated error variance criterion of 18 was used. Of the 1,000 parameter sets run with MODFLOW, 599 fit the selected criteria. The distribution of hydraulic and recharge parameters after the acceptance criteria were applied (fig. 30) was slightly altered from the original parameter sets, but a generally lognormal or normal distribution is indicated. The probability that a recharge location would be in the area contributing recharge to the production wells was determined by dividing the number of times a particle at a given location was captured by a well by the total number of accepted particle-tracking simulations. A Monte Carlo analysis with the maximum pumping rate was also done by using the parameter sets that fit the selected criteria for the average pumping rate. The criteria for the Monte Carlo analysis using the 599 parameter sets with the maximum pumping rate was a water budget of 0.5 percent or less. Of the 599 parameter sets, 584 sets or 97 percent fit these criteria and thus were run with the particle tracking program (table 5).

The probabilistic areas contributing recharge to the production wells at the average pumping rate and the maximum pumping rate are shown in figures 31 and 32; probabilities are expressed as a percentage. The sizes of the probabilistic contributing areas are larger than the deterministic contributing areas; this indicates that some areas not in the deterministic contributing area may actually be in the contributing area.

At the average pumping rate, areas with high probabilities (greater than 50 percent) are on the same side of the nearby stream as the production wells, at and near the wells. The deterministic contributing area on this side of the stream generally coincides with these high probabilities. There is 

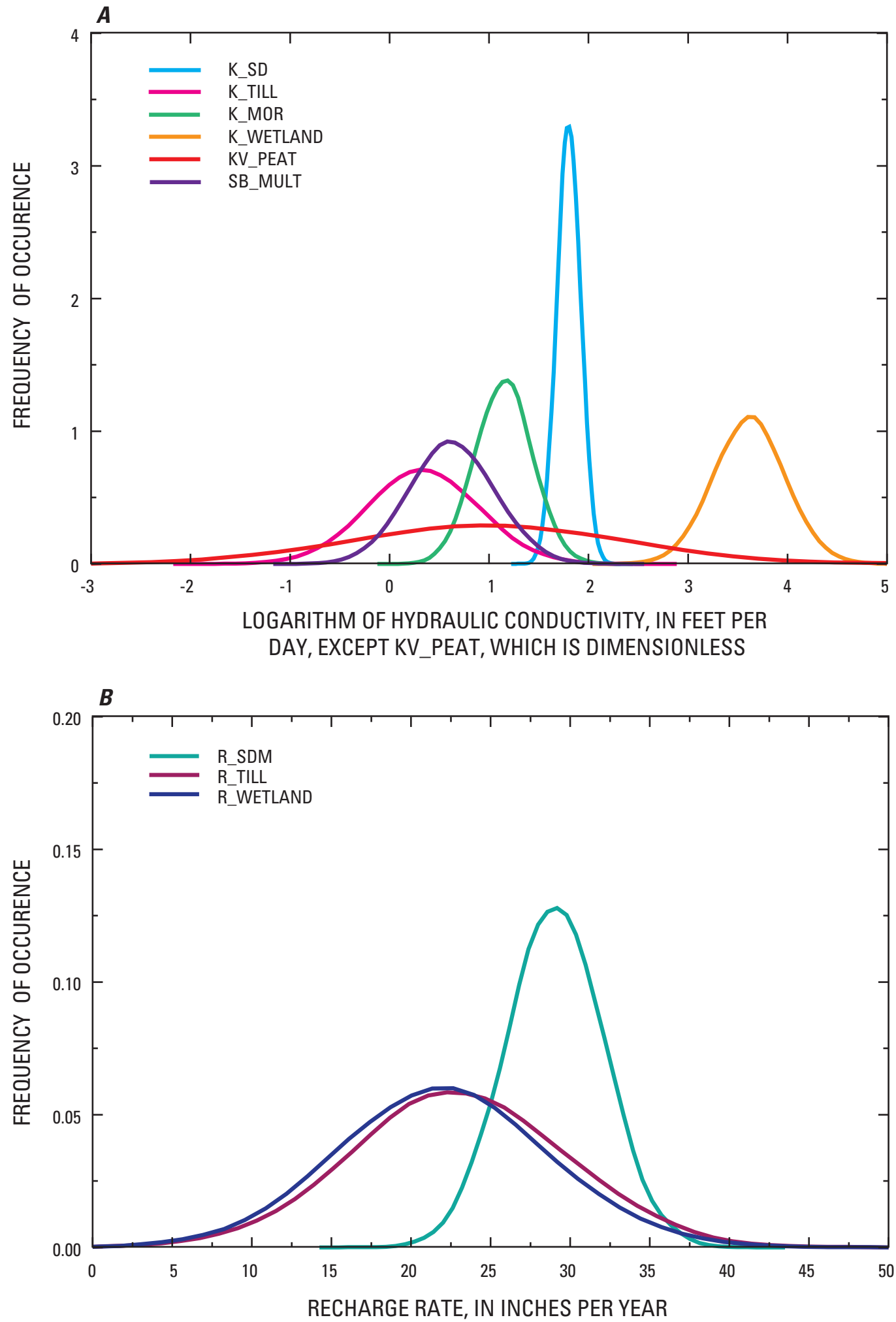

Figure 29. Frequency distribution of $A$, hydraulic parameters, and of $B$, recharge parameters, before acceptance criteria were applied to determine the probabilistic areas contributing recharge to the Central Beach Fire District and East Beach Water Association well fields (parameter information is provided on table 4), Charlestown study site, southern Rhode Island. 
Table 5. Summary of the Monte Carlo analysis for the Charlestown study site, southern Rhode Island.

[CBFD, Central Beach Fire District; EBWA, East Beach Water Association; mi², square mile; KV_Peat, ratio of horizontal to vertical hydraulic conductivity of peat deposits]

\begin{tabular}{|c|c|c|c|c|}
\hline \multirow{2}{*}{ Comment } & \multirow{2}{*}{$\begin{array}{c}\text { Calculated } \\
\text { error variance } \\
\text { criterion }\end{array}$} & \multirow{2}{*}{$\begin{array}{l}\text { Number of parameter sets } \\
\text { run with MODFLOW: } \\
\text { Number of parameter sets } \\
\text { that fit criteria' }\end{array}$} & \multicolumn{2}{|c|}{$\begin{array}{c}\text { Total size of probabilistic contributing } \\
\text { area to CBFD \& EBWA wells }\end{array}$} \\
\hline & & & $\begin{array}{c}\text { Number of particles } \\
\text { or cells }\end{array}$ & $\begin{array}{l}\text { Area } \\
\left(\mathrm{mi}^{2}\right)\end{array}$ \\
\hline \multicolumn{5}{|c|}{ Average pumping rate } \\
\hline KV_Peat conditioned & 6 & $1,000: 224$ & 530 & 0.0684 \\
\hline KV_Peat conditioned & 15 & $1,000: 591$ & 676 & 0.0873 \\
\hline KV_Peat conditioned & 18 & $1,000: 599$ & 677 & 0.0874 \\
\hline KV_Peat conditioned & None & $1,000: 620$ & 725 & 0.0936 \\
\hline \multicolumn{5}{|c|}{ Maximum pumping rate } \\
\hline
\end{tabular}

${ }^{1}$ Criteria: (1) model converged, (2) mass balance 0.5 percent or less, and (3) for some cases, a calculated error variance less than a specified value.

less spread of low probabilities on the production-well side of the stream, most likely because this area is close to the wells and is constrained by model boundaries and the groundwater mound southwestward. On the side of the stream opposite the production wells, probabilities decrease in a radially outward pattern; three quarters of the deterministic contributing area on this side of the stream coincides with probabilities greater than 10 percent to 50 percent, with the remaining deterministic contributing area in an area associated with probabilities of 10 percent or less. Areas associated with low probabilities extend northward on the west side of a simulated groundwater divide, and they include precipitation recharge originating in the till uplands.

At the maximum withdrawal rate, areas with probabilities greater than 50 percent generally coincide with the deterministic contributing area. Generally, areas with shorter traveltimes are associated with higher probabilities and are more likely to coincide with the deterministic contributing area than areas with longer traveltimes associated with lower probabilities. Areas with low probabilities extend north through the middle of Quonochontaug Neck to the mainland. These low probabilities include small isolated areas remote from the production wells, and they include recharge originating in the Charlestown Moraine near the divide between the South Coastal watershed and the Pawcatuck River watershed.

Uncertainty in the simulated areas contributing recharge may be reduced by additional observations of water level and streamflow and by other types of field measurements. Additional observations may increase the precision of estimated parameter values. Additional observations may also help to increase the number of parameters that could be estimated using nonlinear regression by providing more information and (or) by reducing parameter correlations. Specifically, streamflow observations may reduce parameter correlations for recharge parameters, which conceptually are very important for determining contributing areas. Increasing the number of parameters estimated by nonlinear regression, thereby decreasing need for using prior information, would allow an uncertainty analysis based solely on objective model-calibration data. Knowledge of the average altitudes of Block Island Sound and the coastal ponds Quonochontaug and Ninigret would reduce model-design uncertainty. 

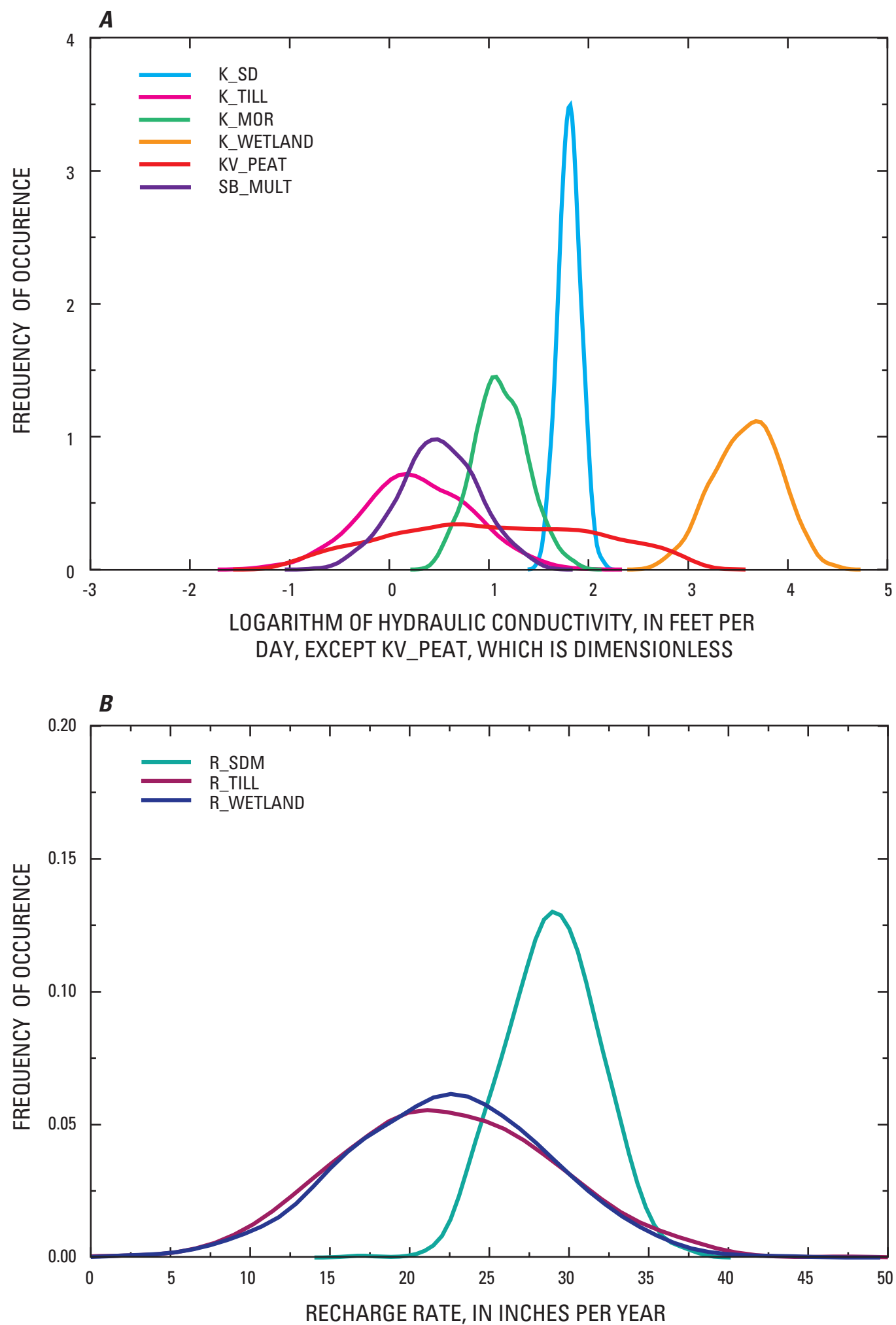

Figure 30. Frequency distribution of $A$, hydraulic parameters, and of $B$, recharge parameters, after acceptance criteria were applied to determine the probabilistic areas contributing recharge to the Central Beach Fire District and East Beach Water Association well fields (parameter information is provided on table 4), Charlestown study site, southern Rhode Island. 


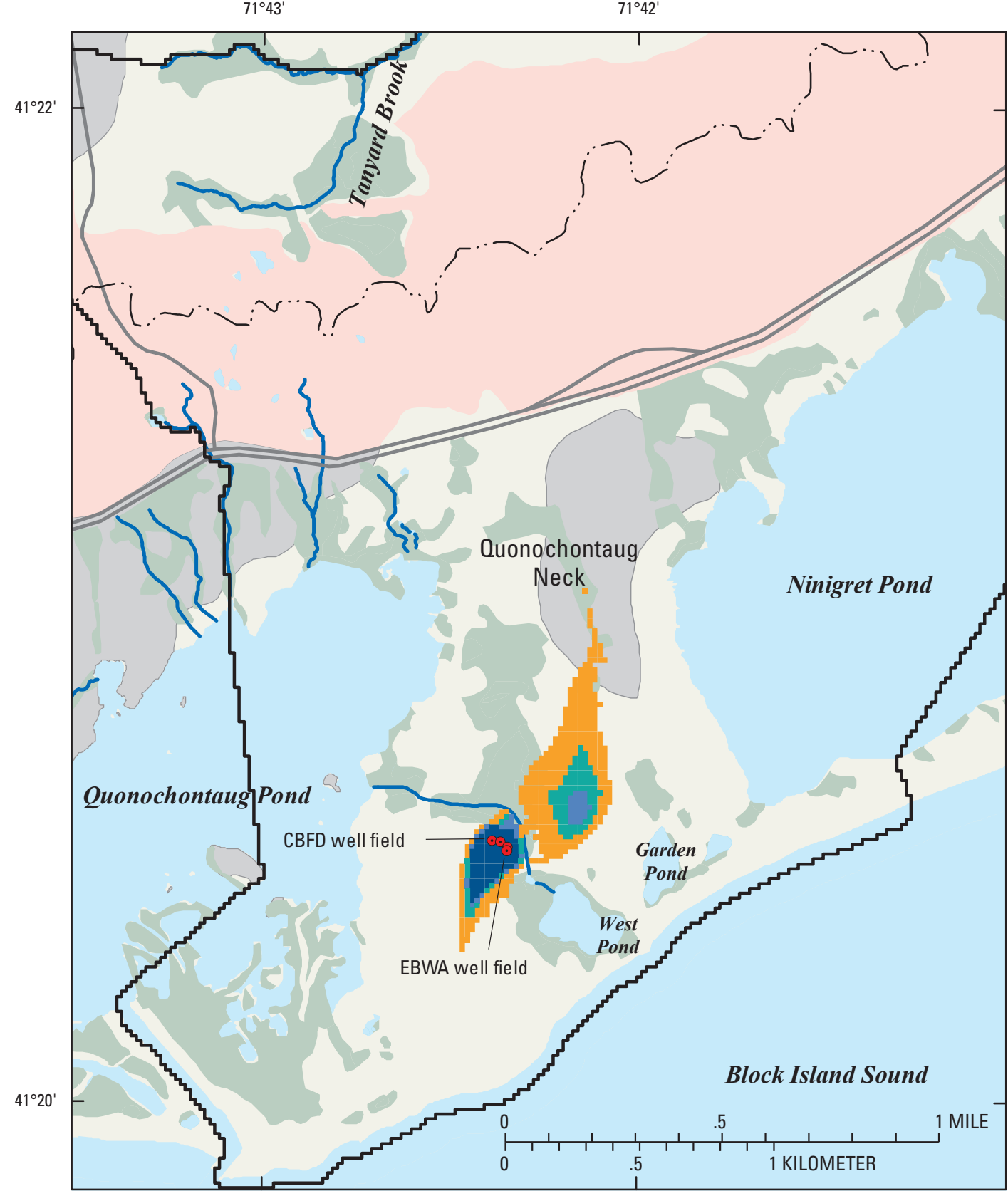

Base from U.S. Geological Survey,

Rhode Island state plane projection, 1:24,000, NAD 83

\section{EXPLANATION}

Probablistic contributing areas to

Central Beach Fire District and East Beach

Water Associations well fields, in percent

Greater than 0 to 10

Greater than 10 to 25

Greater than 25 to 50

Greater than 50 to 100

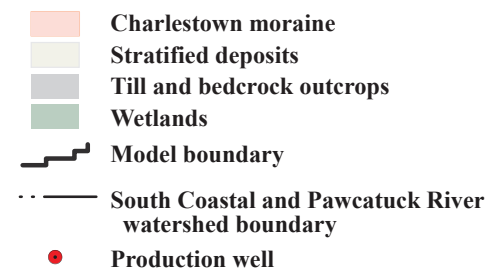

Figure 31. Simulated probabilistic areas contributing recharge to the Central Beach Fire District and East Beach Water Association well fields at their total average pumping rate of 16 gallons per minute, Charlestown study site, southern Rhode Island. 


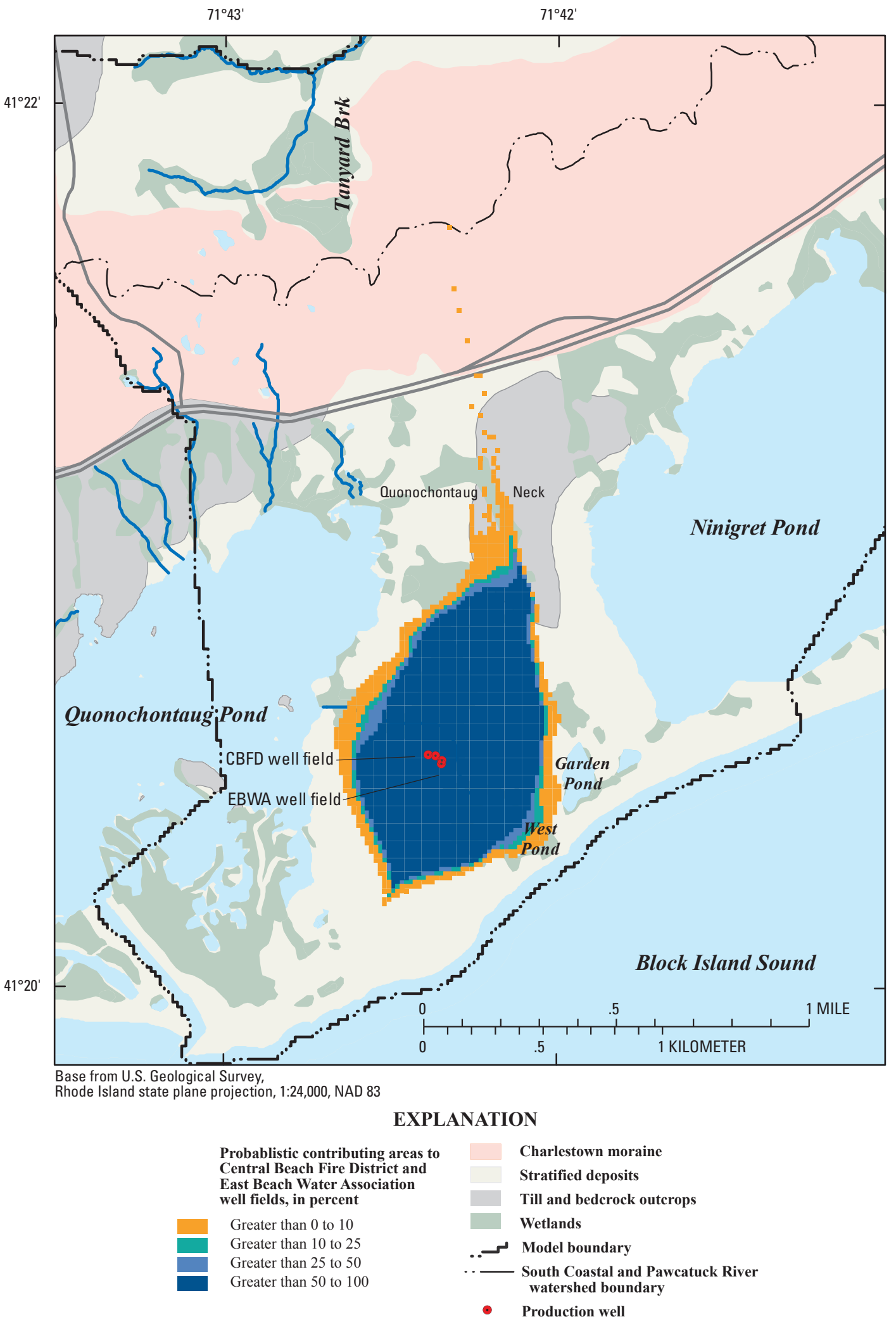

Figure 32. Simulated probabilistic areas contributing recharge to the Central Beach Fire District and East Beach Water Association well fields at their total maximum pumping rate of 230 gallons per minute, Charlestown study site, southern Rhode Island. 


\section{Summary and Conclusions}

The U.S. Geological Survey (USGS), in cooperation with the Rhode Island Department of Health, Office of Drinking Water Quality, began a 2-year investigation in 2006 to increase understanding of groundwater flow and the areas contributing recharge to four well fields in South Kingstown and Charlestown in southern Rhode Island. The well fields are screened in surficial sediments of glacial origin in wetland and coastal settings. Areas contributing recharge to the well fields were determined on the basis of numerical steady-state groundwater-flow models representing longterm average hydrologic conditions. The groundwater-flow models were calibrated to field observations collected during this and previous studies by inverse modeling using nonlinear regression. Summary statistics from nonlinear regression were used to provide a quantitative measure of model-prediction uncertainty. The area contributing recharge to a well is defined as the surface area where water recharges the groundwater and then flows toward and discharges to the well.

In South Kingstown, two UWRI well fields, composed of seven production wells, are in Mink Brook watershed and near Worden Pond and wetlands of large areal extent. Mink Brook is a small intermittent stream that drains $1.82 \mathrm{mi}^{2}$ at its confluence with Worden Pond in the Chipuxet River watershed. The wells are screened in sand and gravel deposits of a glacial morphosequence with saturated thicknesses greater than $100 \mathrm{ft}$ at the well field closest to the preglacial valley axis and about $70 \mathrm{ft}$ at the well field closest to the valley-upland contact. Wetland deposits of peat in the vicinity of the well fields range from less than $1 \mathrm{ft}$ near the edges of the wetland to greater than $11 \mathrm{ft}$ in central areas; thicknesses generally range from 5 to $8 \mathrm{ft}$. Stage measurements in Mink Brook and the wetlands and water levels in a vertical nest of piezometers installed in the peat and sand and gravel deposits near each well field indicated a downward gradient during pumping conditions, and thus the potential for surface water to infiltrate the underlying aquifer. An analytical method to determine hydraulic properties based on water-level drawdowns was used at one piezometer site when the nearby well field pumped $1,350 \mathrm{gal} / \mathrm{min}$ during 90 percent of a 20 -day period. Transmissivity estimated for the sand and gravel deposits was $18,900 \mathrm{ft}^{2} / \mathrm{d}$, which is within the range of previously reported values at the well field. The analysis indicated that the vertical hydraulic conductivity of the peat, which controls vertical flow between the surface water and the aquifer, was roughly $0.01 \mathrm{ft} / \mathrm{d}$.

Groundwater flow at the South Kingstown study site was simulated by a five-layer model representing surficial deposits and the underlying bedrock. The model was calibrated to 135 water-level observations and 5 streamflow observations. Boundary conditions and hydraulic properties were represented by 18 parameters: 3 recharge parameters, 9 horizontal hydraulic-conductivity parameters, 5 vertical anisotropy parameters, and 1 multiplier of streambed vertical hydraulic conductivity. One of the recharge parameters, which represented water available for recharge in the wetlands, was specified in the model, but it was included in modelprediction uncertainty. Nine parameters were estimated by nonlinear regression; observations did not provide enough information on the remaining parameters, most of which represented vertical anisotropies of the surficial deposits and hydraulic properties of bedrock, and these parameters were therefore specified in the model based on reported values. A model-fit statistic, the calculated error variance, which is a measure of the overall magnitude of the weighted residuals (differences between observed and simulated water levels and streamflows), was 5.32. Influence statistics indicated that nine water-level and four streamflow observations had the most overall influence in the regression and the set of estimated parameters; four of the five streamflow observations were influential, indicating the importance of streamflow observations in model calibration. The estimated optimal parameter value for recharge to stratified and morainal deposits was $29.0 \mathrm{in} / \mathrm{yr}$ and to till deposits was $23.1 \mathrm{in} / \mathrm{yr}$. Estimated optimal values for horizontal hydraulic conductivity parameters were as follows: stratified deposits, 137 and $332 \mathrm{ft} / \mathrm{d}$; till deposits, 3.8 and $7.9 \mathrm{ft} / \mathrm{d}$; Charlestown and Point Judith Moraines, $16 \mathrm{ft} / \mathrm{d}$; and a small area of mixed deposits of stratified, till, and undifferentiated morainal deposits, $26 \mathrm{ft} / \mathrm{d}$. The optimal parameter value for the streambed multiplier was equivalent to vertical hydraulic conductivities of $1.8 \mathrm{ft} / \mathrm{d}$ for coarse-grained bed sediments and $0.18 \mathrm{ft} / \mathrm{d}$ for organic-rich bed sediments. Optimal values for the two recharge parameters and the parameter representing a mix of surficial deposits were the most precisely estimated, whereas the streambed hydraulic conductivities were the least precisely estimated.

The simulated area contributing recharge to the UWRI well fields at the average pumping rates during 2003-07 (total rate of 2,138 gal $/ \mathrm{min}$ ) extended to groundwater divides in mostly till and morainal deposits, and it covered $2.30 \mathrm{mi}^{2}$. Most of a sand and gravel mining operation, which is between the well fields and near Mink Brook, was in the simulated contributing area. Precipitation recharge in some areas near small simulated streams in Mink Brook watershed and Alewife Brook watershed, which share a common boundary in transmissive stratified deposits, discharged to the streams instead of being captured by the well fields. At the maximum pumping capacities for the well fields (total rate of $5,100 \mathrm{gal} / \mathrm{min}$ ), the contributing area expanded to $5.54 \mathrm{mi}^{2}$ and intercepted additional groundwater and infiltration of surface water. Most of the precipitation recharge in Mink Brook and Alewife Brook watersheds was intercepted by the well fields, and simulated streams ceased to flow. The maximum pumping rate shifted the simulated groundwater divides and captured groundwater that would have discharged to adjacent watersheds under average pumping conditions. The contributing area included an area beneath Worden Pond and a remote, isolated area in upland till on the side of Worden Pond opposite the well fields. Particle tracks indicated that recharge originating in this upland till travels along deep 
groundwater-flow paths in the valley-fill deposits and, under pumping conditions, passes beneath Worden Pond to one of the well fields. About 12 percent of the pumped water was from surface water, primarily Worden Pond; this pondwater infiltration is less than four percent of the long-term average streamflow entering the pond. Simulated groundwater traveltimes from recharge locations to production wells for the maximum pumping rate ranged from less than 1 year to greater than 500 years; 59 percent of the traveltimes were 10 years or less.

Parameter uncertainty and associated effects on the simulated area contributing recharge to the well fields were evaluated using a Monte Carlo analysis. Optimal parameter values and the parameter variance-covariance matrix from nonlinear regression were used to create parameter sets for the analysis. Two unestimated parameters (water available for recharge in the wetlands and vertical hydraulic conductivity of the peat) that are important for model predictions were incorporated into the variance-covariance matrix. The observations provided enough information to constrain the uncertainty of these parameters within a realistic range around the specified values of $22 \mathrm{in} / \mathrm{yr}$ and $0.1 \mathrm{ft} / \mathrm{d}$, respectively, for these highly variable and poorly understood parameters. The 95-percent confidence intervals were 10.1 and $33.8 \mathrm{in} / \mathrm{yr}$ for wetland recharge and 0.006 and $1.5 \mathrm{ft} / \mathrm{d}$ for vertical hydraulic conductivity of the peat. Of 1,000 parameter sets, 749 that fit a criterion for water budget and a criterion for calculated error variance for the average pumping rate were used in the uncertainty analysis. The maximum pumping rate scenario used these 749 parameter sets with a water-budget criterion. The size of the probabilistic contributing area for both the average and maximum pumping rates was larger than the size of the deterministic contributing areas because of the effects of parameter uncertainty; this indicates that some areas not in the deterministic contributing areas may actually be in the contributing area. For both pumping rates, the deterministic contributing area generally coincides with areas associated with high probabilities (greater than 50 percent). For the average pumping rate, in addition to areas with low probabilities distant from the well fields, areas where simulated streams intercepted precipitation recharge in the calibrated model were associated with generally low probabilities, indicating that this recharge may instead go directly to a well. That part of the sand and gravel mining operation between the well fields and not in the deterministic contributing area was in the probabilistic contributing area, including some areas with high probabilities. For the maximum pumping rate, some areas on the opposite side of Worden Pond from the well fields that are not in the deterministic contributing area are in the probabilistic contributing area but at mostly low probabilities. A sensitivity analysis showed that by decreasing recharge rates or the hydraulic connection between surface water and the aquifer, the simulated contributing area at the maximum pumping rate expanded primarily by intercepting groundwater that originated on the opposite side of Worden Pond.
In Charlestown the CBFD and EBWA well fields, each composed of two production wells, are on a $0.85 \mathrm{mi}^{2}$ peninsula bounded by Block Island Sound and large saltwater ponds. The wells are screened in a coarse-grained, ice-proximal part of a morphosequence with saturated thicknesses generally less than $30 \mathrm{ft}$ on the peninsula. Streamflow measured in a stream and associated wetlands near the well fields indicated an average net gain of $0.09 \mathrm{ft}^{3} / \mathrm{s}$ at approximately average hydrologic conditions. Measured peat thicknesses generally ranged from 2 to $4 \mathrm{ft}$.

Groundwater flow was simulated by a four-layer model representing surficial deposits and the bedrock. The model was calibrated to 46 water-level and 1 streamflow observations. The model was represented by 14 parameters -3 recharge parameters, 5 horizontal hydraulic-conductivity parameters, 5 vertical anisotropy parameters, and a multiplier of streambed hydraulic conductivity. Available observations did not provide enough information to estimate parameters representing vertical anisotropies of surficial deposits and hydraulic properties of the bedrock. In addition, two sets of parameters (recharge rate to stratified and morainal deposits, and the horizontal hydraulic conductivity of the stratified deposits; recharge rate to till deposits, and the horizontal hydraulic conductivity of till deposits) were too highly correlated to be estimated uniquely. The recharge parameters, including a parameter that represented water available for recharge in the wetlands and the parameters that were insensitive to available observations, were specified in the model on the basis of reported values and parameter-estimation results from the South Kingstown study site. Five parameters (four horizontal hydraulic conductivities and the streambed multiplier) were estimated by nonlinear regression. The calculated error variance was 3.03. Influence statistics indicated that the streamflow observation, in addition to being one of four observations influential to the set of estimated parameters values, was the only observation important to more than two individual estimated parameter values. Estimated optimal values for glacial horizontal hydraulic-conductivity parameters were as follows: stratified deposits, $64 \mathrm{ft} / \mathrm{d}$; till deposits, $2.2 \mathrm{ft} / \mathrm{d}$; and the Charlestown Moraine, $14 \mathrm{ft} / \mathrm{d}$. The optimal value for a parameter that represented the lack of resistance to surface-water flow in the wetland and groundwater flow in poorly decomposed peat was $4,200 \mathrm{ft} / \mathrm{d}$. The optimal parameter value for the streambed multiplier was equivalent to hydraulic conductivities of $4.3 \mathrm{ft} / \mathrm{d}$ for coarse-grained bed sediments and $0.43 \mathrm{ft} / \mathrm{d}$ for organic-rich bed sediments. The optimal parameter value for the horizontal hydraulic conductivity of stratified deposits was the most precisely estimated, and the streambed hydraulic conductivities were the least precisely estimated.

The simulated area contributing recharge for the combined average pumping rates during 2003-07 (16 gal $/ \mathrm{min})$ for the CBFD and EBWA well fields included $0.018 \mathrm{mi}^{2}$. The contributing area extended southwestward from the well fields to a simulated groundwater mound, it underlay a small part of the adjacent wetlands, and it included isolated 
areas on the side of the wetland opposite to the well fields. For the maximum pumping rate $(230 \mathrm{gal} / \mathrm{min})$, the simulated contributing area $\left(0.26 \mathrm{mi}^{2}\right)$ expanded in all directions to capture enough water to balance the increased pumping rate. The contributing area included precipitation recharge originating in a till area on the peninsula, and it underlay part of a nearby pond. Because the wells are screened in a thin aquifer, simulated traveltimes from recharge locations to the production wells were relatively short: 94 percent of the traveltimes were 10 years or less, and the median traveltime was 1.3 years.

Four unestimated parameters that may be important for quantifying prediction uncertainty ( 3 recharge parameters and a peat vertical hydraulic-conductivity parameter) were included in the variance-covariance matrix for the Monte Carlo analysis. Including these four parameters, however, led to unrealistic uncertainties about the specified parameter value because of insufficient information provided by the observations. Prior information was used to constrain parameter uncertainties to realistic ranges so that model-prediction uncertainty was not overestimated. Of 1,000 parameter sets, 599 that fit a criterion for water budget and a criterion for calculated error variance for the average pumping rate were used in the analysis. The maximum pumping rate scenario used these 599 parameter sets with a water-budget criterion. For the average pumping rate, areas associated with high probabilities were only on the well-field side of the nearby wetlands; the deterministic contributing area on this side of the wetland corresponded to this area of high probability. On the opposite side of the wetland from the well fields, probabilities decreased in a radially outward pattern. Areas associated with low probabilities extended to the till area on the peninsula. For the maximum pumping rate, areas associated with high probabilities generally corresponded with the deterministic contributing area. Areas with low probabilities extended through the middle of the peninsula to the mainland, and they included small isolated areas remote from the well fields.

\section{Acknowledgments}

The author expresses appreciation to Clay Commons (Source Water Assessment Coordinator, RIDOH, Office of Drinking Water Quality) for initiating and supporting the study, and to Richard Amirault (RIDOH), Ernie Panciera (RIDEM), and Theodore Peters (RIDEM) for their suggestions during the study. The author thanks Jeffrey Starn (USGS, Connecticut Water Science Center) for providing a computer program to facilitate the Monte Carlo analysis and for his insights into the method, and Janet Stone (USGS Geologic Discipline, Connecticut) for her guidance in constructing the geologic sections. Finally, the author appreciates the assistance of Stanley Knox (Manager, UWRI), Neil Williamson (Chief
Operator, UWRI), William Meyer (CBFD), and Peter Ogle (EBWA) for information concerning groundwater withdrawals and for their assistance in coordinating field activities.

\section{References Cited}

Allen, W.B., Hahn, G.W., and Brackley, R.A., 1966, Availability of ground water, upper Pawcatuck River Basin, Rhode Island: U.S. Geological Survey Water-Supply Paper 1821, 66 p., 3 sheets.

Allen, W.B., Hahn, G.W., and Tuttle, C.R., 1963, Geohydrological data for the upper Pawcatuck River Basin, Rhode Island: Rhode Island Water Resources Coordinating Board Geological Bulletin 13, 68 p., 1 plate, scale 1:24,000.

Bent, G.C., 1995, Streamflow, ground-water recharge and discharge, and characteristics of surficial deposits in Buzzards Bay Basin, southeastern Massachusetts: U.S. Geological Survey Water-Resources Investigations Report 95-4234, $56 \mathrm{p}$.

Bent, G.C., 1999, Streamflow, base flow, and groundwater recharge in the Housatonic River Basin, western Massachusetts and parts of eastern New York and northwestern Connecticut: U.S. Geological Survey WaterResources Investigations Report 98-4232, 68 p.

Bierschenk, W.H., 1956, Ground-water resources of the Kingston quadrangle, Rhode Island: Rhode Island Development Council Geological Bulletin 9, 60 p., 2 plates, scale 1:31,680.

Boothroyd, J.C., 2001, Quaternary Geology of the Carolina and Quonochontaug Quadrangles, Washington County, Rhode Island: Rhode Island Geological Survey Open File 01-2001, 19 p.

Boothroyd, J.C., Freedman, J.H., Brenner, H.B., and Stone, J.R., 1998, The glacial geology of southern Rhode Island, in Murray, D.P., (ed.), New England Intercollegiate Geological Conference, 90th annual meeting, Kingston, RI, October 9-11, 1998, Guidebook for fieldtrips in Rhode Island and adjacent regions of Connecticut and Massachusetts: trip C5, 25 p.

de Lima, V., 1991, Stream-aquifer relations and yield of stratified-drift aquifers in the Nashua River Basin, Massachusetts: U.S. Geological Survey Water-Resources Investigations Report 88-4147, $47 \mathrm{p}$.

DeSimone, L.A., 2004, Simulation of ground-water flow and evaluation of water-management alternatives in the Assabet River Basin, eastern Massachusetts: U.S. Geological Survey Scientific Investigations Report 2004-5119, 133 p. 
Dickerman, D.C., 1984, Aquifer tests in the stratified drift, Chipuxet River Basin, Rhode Island: U.S. Geological Survey Water-Resources Investigations Report 83-4231, $39 \mathrm{p}$.

Dickerman, D.C., Trench, E.C.T., and Russell, J.P., 1990, Hydrogeology, water quality, and ground-water development alternatives in the lower Wood River groundwater reservoir, Rhode Island: U.S. Geological Survey Water-Resources Investigation Report 89-4031, 109 p.

Dillion, W.P., 1970, Submergence effects on a Rhode Island barrier and lagoon and inferences on migration of barriers: Journal of Geology, v. 78, p. 94-106.

Farnsworth, R.K., Thompson, E.S., and Peck, E.L., 1982, Evaporation atlas for the contiguous 48 United States: U.S. Department of Commerce, National Oceanic and Atmospheric Administration, Technical Report NWS 33, 26 p., 4 plates.

Friesz, P.J., 1996, Geohydrology of stratified drift and streamflow in the Deerfield River Basin, northwestern Massachusetts: U.S. Geological Survey Water-Resources Investigations Report 96-4115, 49 p., 1 plate.

Friesz, P.J., 2004, Delineation of areas contributing recharge to selected public-supply wells in glacial valley-fill and wetland settings, Rhode Island: U.S. Geological Survey Scientific Investigations Report 2004-5070, 57 p.

Friesz, P.J., and Church, P.E., 2001, Pond-aquifer interaction at South Pond of Lake Cochituate, Natick, Massachusetts: U.S. Geological Survey Water-Resources Investigations Report 01-4040, $42 \mathrm{p}$.

Friesz, P.J., and Stone, J.R., 2007, Simulation of ground-water flow and areas contributing recharge to production wells in contrasting glacial valley-fill settings, Rhode Island: U.S. Geological Survey Scientific Investigations Report 2007-5133, $50 \mathrm{p}$.

Gonthier, J.B., Johnston, H.E., and Malmberg, G.T., 1974, Availability of ground water in the Lower Pawcatuck River Basin, Rhode Island: U.S. Geological Survey Water-Supply Paper 2033, 40 p., 4 plates.

Guthrie, R.C., and Stolgitis, J.A., 1977, Fisheries investigations and management in Rhode Island lakes and ponds, Fisheries Report No. 3: Rhode Island Department of Natural Resources, Division of Fish and Wildlife, 256 p.

Hantush, M.S., 1956, Analysis of data from pumping tests in leaky aquifers: American Geophysical Union Transactions, v. 37 , no. 6 , p. $702-714$.

Hantush, M.S., and Jacob, C.E., 1955, Nonsteady radial flow in an infinite leaky aquifer: American Geophysical Union Transactions, v. 36, no. 1, p. 95-1000.
Harbaugh, A.W., Banta, E.R., Hill, M.C., and McDonald, M.G., 2000, MODFLOW-2000, The U.S. Geological Survey modular ground-water model-user guide to modularization concepts and the ground-water flow process: U.S. Geological Survey Open-File Report 00-92, 121 p.

Hemond, H.F., 1980, Biogeochemistry of Thoreau's Bog, Concord, Massachusetts: Ecological Monographs, v. 50, no. 4 , p. 507-526.

Hill, M.C., Banta, E.R., Harbaugh, A.W., and Anderman, E.R., 2000, MODFLOW-2000, the U.S. Geological Survey modular ground-water model-User guide to the observation, sensitivity, and parameter-estimation processes and three post-processing programs: U.S. Geological Survey Open-File Report 00-184, 209 p.

Hill, M.C., and Tiedeman, C.R., 2007, Effective groundwater model calibration - with analysis of data, sensitivities, predictions, and uncertainty: Hoboken, NJ, John Wiley and Sons, Inc., 455 p.

Johnston, H.E., and Dickerman, D.C., 1974, Availability of ground water in the Blackstone River area, Rhode Island and Massachusetts: U.S. Geological Survey WaterResources Investigations Report 4-74, 2 sheets.

Kaye, C.A., 1960, Surficial geology of the Kingston quadrangle, Rhode Island: U.S. Geological Survey Geological Bulletin 1071-I, p. 341-396, 3 plates, scale $1: 24,000$.

Lapham, W.W., 1989, Use of temperature profiles beneath streams to determine rates of vertical ground-water flow and vertical hydraulic conductivity: U.S. Geological Survey Water-Supply Paper 2337, 35 p.

LaSala, A.M., Jr., and Hahn, G.W., 1960, Ground-water map of the Carolina quadrangle, Rhode Island: Rhode Island Water Resources Coordinating Board GWM-9, scale $1: 24,000$.

LaSala, A.M., Jr., and Johnson, K.E., 1960, Ground-water map of the Quonochontaug quadrangle, Rhode Island: Rhode Island Water Resources Coordinating Board GWM-11, scale 1:24,000.

LeBlanc, D.R., 1987, Fate and transport of contaminants in sewage-contaminated ground water on Cape Cod, Massachusetts in Franks, B.J., ed., U.S. Geological Survey program on toxic waste-groundwater-contamination: Proceedings of the third technical meeting, Pensacola, Florida, March 23-27, 1987, U.S. Geological Survey Open-File Report 87-109, p. B3-B7. 
Lyford, F.P., and Cohen, A.J., 1988, Estimation of water available for recharge to sand and gravel aquifers in the glaciated northeastern United States, in Randall, A.D., and Johnson, A.I., eds., Regional aquifer systems of the United States-The northeast glacial aquifers: American Water Resources Association Monograph Series, no. 11, p. 37-61.

Masterson, J.P., Sorenson, J.R., Stone, J.R., Moran, S.B., Hougham, A., 2007, Hydrogeology and simulated groundwater flow in the Salt Pond region of southern Rhode Island: U.S. Geological Survey Scientific Investigations Report 2006-5271, 56 p.

Mazzaferro, D.L., Handman, E.H., and Thomas, M.P., 1979, Water resources inventory of Connecticut, part 8, Quinnipiac River Basin: Connecticut Water Resources Bulletin, no. 27, 88 p.

McDonald, M.G., and Harbaugh, A.W., 1988, A modular three-dimensional finite-difference ground-water flow model: U.S. Geological Survey Techniques of Water Resources Investigations, book 6, chap. A-1, 586 p.

Meinzer, O.E., 1923, The occurrence of ground water in the United States, with a discussion of principles: U.S. Geological Survey Water-Supply Paper 489, 321 p.

Melvin, R.L., de Lima, V., and Stone, B.D., 1992, The stratigraphy and hydraulic properties of tills in southern New England: U.S. Geological Survey Open-File Report 91-481, 53 p.

Mitsch, W.J., and Gosselink, J.G., 1993, Wetlands (2d ed.): New York, Van Nostrand Reinhold, 722 p.

Moore, G.E., Jr., 1959, Bedrock geology of the Carolina and Quonochontaug quadrangles, Rhode Island: U.S. Geological Survey Geologic Quadrangle Map 117, scale 1:31,680.

Moore, G.E., Jr., 1964, Bedrock geology of the Kingston quadrangle, Rhode Island: U.S. Geological Survey Geological Bulletin 1158-E, p. E1-E21, 1 plate, scale $1: 24,000$.

National Oceanic and Atmospheric Administration, 2008, Annual climatological summary, accessed October 2008 at http://cdo.ncdc.noaa.gov/ancsum/ACS.

O'Brien, A.L., 1977, Hydrology of two small wetland basins in eastern Massachusetts: Water Resources Bulletin, v. 13, no. 2 , p. 325-340.

Pollock, D.W., 1994, User's guide for MODPATH/ MODPATH_PLOT, version 3: A particle tracking postprocessing package for MODFLOW, the U.S. Geological Survey finite-difference ground-water flow model: U.S. Geological Survey Open-File Report 94-464, variously paged.
Prudic, D.E., 1989, Documentation of a computer program to simulate stream-aquifer relations using a modular, finitedifference, ground-water flow model: U.S. Geological Survey Open-File Report 88-729, 113 p.

Randall, A.D., Thomas, M.P., Thomas, C.E., Jr., and Baker, J.A., 1966, Water resources inventory of Connecticut; Part 1, Quinebaug River Basin: Connecticut Water Resources Bulletin no. 8, 102 p.

Reilly, T.E., and Pollock, D.W., 1993, Factors affecting areas contributing recharge to wells in shallow aquifers: U.S. Geological Survey Water-Supply Paper 2412, 21 p.

Rosenshein, J.R., Gonthier, J.B., and Allen, W.B., 1968, Hydrologic characteristics and sustained yield of principal ground-water units, Potowomut-Wickford area, Rhode Island: U.S. Geological Survey Water-Supply Paper 1775, 38 p., 5 plates.

Starn, J.J., Stone, J.R., and Mullaney, J.R., 2000, Delineation and analysis of uncertainty of contributing areas to wells at the Southbury Training School, Southbury, Connecticut: U.S. Geological Survey Water-Resources Investigations Report 00-4158, $53 \mathrm{p}$.

Stone, J.R., Schafer, J.P., London, E.H., DiGiacomo-Cohen, M.L, Lewis, R.S., and Thompson, W.B., 2005, Quaternary geologic map of Connecticut and Long Island Sound Basin: U.S. Geological Survey Scientific Investigations Map SIM-2784, 1:125,000 scale, with accompanying text, $72 \mathrm{p}$.

Theis, C.V., 1935, The relation between the lowering of the piezometric surface and the rate and duration of discharge of a well using groundwater storage: American Geophysical Union Transactions, v. 16, p. 519-524.

Tiedeman, C.R., Goode, D.J., and Hsieh, P.A., 1997, Numerical simulation of ground-water flow through glacial deposits and crystalline bedrock in the Mirror Lake area, Grafton County, New Hampshire: U.S. Geological Survey Professional Paper 1572, $50 \mathrm{p}$.

Tiner, R.W., 1989, Wetlands of Rhode Island: Newton Corner, MA: U.S. Fish and Wildlife Service, National Wetlands Inventory, variously paged.

Urish, D.W., 1992, Water resources of the Central Beach Fire District, Quonochontaug, Rhode Island: South Kingstown, RI, variously paged.

Urish, D.W., 2000, Groundwater resources of the Central Beach and East Beach Water Systems, Quonochontaug, Rhode Island: South Kingstown, RI, variously paged.

U.S. Environmental Protection Agency, 1991, Protecting the nation's ground water: EPA's strategy for the 1990's: U.S. Environmental Protection Agency, Office of the Administrator, Report 21Z-1020, 84 p. 
U.S. Geological Survey, 1980, Accuracy specifications for topographic mapping, in Technical instructions of the National Mapping Division: Reston, Virginia, chap. 1B4, p. 1-13.

U.S. Geological Survey, 2008, Historical water conditions statements, accessed October 2008 at http://ma.water.usgs. gov/current_cond/cwrc_statements.htm.

U.S.Geological Survey, 2007, Water-resources data for the United States, water year 2006: U.S. Geological Survey Water-Data Report WDR-US-2006, accessed September 2008 at http://wdr.water.usgs.gov.

Verry, E.S., and Boelter, D.H., 1979, Peatland hydrology, in Greeson, P.E., Clark, J.R., and Clark, J.E., eds., Wetland functions and values - the state of our understanding: Proceedings of the National Symposium on Wetlands, Lake Buena Vista, FL, 1978, Minneapolis, MN, American Water Resources Association, p. 389-402.

Wild, E.C., and Nimiroski, M.T., 2004, Estimated water use and availability in the Pawcatuck Basin, southern Rhode Island and southeastern Connecticut, 1995-99: U.S. Geological Survey Scientific Investigations Report 2004-5020, $72 \mathrm{p}$. 
Appendix 1. Water depth, and thickness of peat and organic-rich sediment (location of profiles shown on figures 3 and 20), South Kingstown and Charlestown study sites, southern Rhode Island.

[ft, foot; coordinates determined by global positioning system at South Kingstown study site and by 1:5,000 orthophoto at Charlestown study site; A, North-south profile near west well field, November 6, 2006; B, West-east profile in Mink Brook near west well field, November 6, 2006; C, North-south profile near east well field, November 7, 2006; D, West-east profile near east well field, November 7 , 2006; and E, West-east profile near east well field, November 7, 2006; F, West-east profile north of Sea Breeze Avenue, December 6 , 2006; and G, West-east profile south of Sea Breeze Avenue, December 6, 2006]

\begin{tabular}{|c|c|c|c|c|}
\hline Profile & $\begin{array}{c}\text { Easting } \\
\text { (ft) }\end{array}$ & $\begin{array}{c}\text { Northing } \\
\text { (ft) }\end{array}$ & $\begin{array}{l}\text { Water depth } \\
\text { (ft) }\end{array}$ & $\begin{array}{c}\text { Thickness of peat and } \\
\text { organic-rich sediment } \\
\text { (ft) }\end{array}$ \\
\hline \multicolumn{5}{|c|}{ South Kingstown study site } \\
\hline A & 313,880 & 128,290 & 0 & 7.5 \\
\hline A & 313,956 & 128,299 & 0 & 6.3 \\
\hline A & 313,979 & 128,276 & 0 & 5.8 \\
\hline A & 313,949 & 128,225 & 0 & 4.3 \\
\hline A & 314,024 & 128,160 & 0 & 5.3 \\
\hline A & 314,000 & 128,113 & 0 & 5.9 \\
\hline A & 313,977 & 128,036 & 0 & 6.1 \\
\hline A & 313,926 & 127,993 & 0 & 7.1 \\
\hline A & 313,930 & 127,947 & 0 & 8.6 \\
\hline A & 313,933 & 127,910 & 0 & 9.4 \\
\hline A & 313,949 & 127,877 & 0 & 7.0 \\
\hline A & 313,984 & 127,863 & 0 & 4.7 \\
\hline A & 313,984 & 127,844 & 1.0 MinkBrook & 4.3 \\
\hline A & 313,998 & 127,832 & 0 & 4.4 \\
\hline A & 313,995 & 127,806 & 0 & 5.7 \\
\hline A & 313,971 & 127,781 & 0 & 6.8 \\
\hline A & 313,978 & 127,748 & 0 & 8.0 \\
\hline A & 313,984 & 127,719 & 0 & 7.6 \\
\hline A & 313,982 & 127,689 & 0 & 6.4 \\
\hline A & 314,014 & 127,658 & 0 & 5.7 \\
\hline A & 314,021 & 127,615 & 0 & 4.6 \\
\hline A & 314,025 & 127,593 & 0 & 3.1 \\
\hline A & 314,012 & 127,577 & 0 & 2.0 \\
\hline A & 313,992 & 127,540 & 0 & 0.8 \\
\hline $\mathrm{B}$ & 313,852 & 127,808 & 1.2 & 4.7 \\
\hline B & 313,881 & 127,807 & 1.3 & 5.7 \\
\hline B & 313,929 & 127,819 & 1.4 & 6.3 \\
\hline B & 314,052 & 127,826 & 0.7 & 4.2 \\
\hline B & 314,101 & 127,797 & 0.7 & 4.8 \\
\hline B & 314,143 & 127,768 & 0.5 & 4.9 \\
\hline $\mathrm{C}$ & 317,861 & 128,228 & 2.1 & 5.0 \\
\hline $\mathrm{C}$ & 317,809 & 128,175 & 0.7 & 5.6 \\
\hline $\mathrm{C}$ & 317,834 & 128,122 & 0.4 & 7.6 \\
\hline $\mathrm{C}$ & 317,831 & 128,050 & 0.5 & 5.6 \\
\hline $\mathrm{C}$ & 317,814 & 128,009 & 0.6 & 5.6 \\
\hline $\mathrm{C}$ & 317,803 & 127,962 & 0.4 & 5.9 \\
\hline
\end{tabular}


Appendix 1. Water depth, and thickness of peat and organic-rich sediment (location of profiles shown on figures 3 and 20), South Kingstown and Charlestown study sites, southern Rhode Island.-Continued

[ft, foot; coordinates determined by global positioning system at South Kingstown study site and by 1:5,000 orthophoto at Charlestown study site; A, North-south profile near west well field, November 6, 2006; B, West-east profile in Mink Brook near west well field, November 6, 2006; C, North-south profile near east well field, November 7, 2006; D, West-east profile near east well field, November 7 , 2006; and E, West-east profile near east well field, November 7, 2006; F, West-east profile north of Sea Breeze Avenue, December 6, 2006; and G, West-east profile south of Sea Breeze Avenue, December 6, 2006]

\begin{tabular}{|c|c|c|c|c|}
\hline Profile & $\begin{array}{l}\text { Easting } \\
\quad(\mathrm{ft})\end{array}$ & $\begin{array}{c}\text { Northing } \\
\text { (ft) }\end{array}$ & $\begin{array}{l}\text { Water depth } \\
\text { (ft) }\end{array}$ & $\begin{array}{l}\text { Thickness of peat and } \\
\text { organic-rich sediment } \\
\text { (ft) }\end{array}$ \\
\hline \multicolumn{5}{|c|}{ South Kingstown study site—continued } \\
\hline $\mathrm{C}$ & 317,715 & 127,894 & 1.0 & 7.9 \\
\hline $\mathrm{C}$ & 317,701 & 127,813 & 2.0 & 7.3 \\
\hline $\mathrm{C}$ & 317,706 & 127,756 & 2.2 & 7.3 \\
\hline $\mathrm{D}$ & 317,375 & 128,302 & 1.7 & 6.6 \\
\hline $\mathrm{D}$ & 317,559 & 128,260 & 0.3 & 7.2 \\
\hline $\mathrm{D}$ & 317,671 & 128,232 & 0.5 & 3.9 \\
\hline $\mathrm{D}$ & 317,728 & 128,245 & 1.1 & 2.4 \\
\hline $\mathrm{D}$ & 317,777 & 128,233 & 0.9 & 2.7 \\
\hline $\mathrm{D}$ & 317,862 & 128,220 & 2.2 & 5.8 \\
\hline $\mathrm{D}$ & 317,925 & 128,269 & 1.4 & 5.9 \\
\hline $\mathrm{D}$ & 317,956 & 128,321 & 0.4 & 3.6 \\
\hline E & 317,536 & 127,942 & 0.3 & 11.7 \\
\hline E & 317,569 & 127,915 & 0.2 & 11.0 \\
\hline \multicolumn{5}{|c|}{ Charlestown study site } \\
\hline $\mathrm{F}$ & 271,710 & 94,400 & 0.4 & 1.2 \\
\hline $\mathrm{F}$ & 271,740 & 94,410 & 0.4 & 4.8 \\
\hline $\mathrm{F}$ & 271,770 & 94,420 & 0.4 & 4.4 \\
\hline F & 271,820 & 94,430 & 0.4 & 1.9 \\
\hline $\mathrm{F}$ & 271,850 & 94,430 & 0.4 & 2.2 \\
\hline F & 271,880 & 94,440 & 0.4 & 2.1 \\
\hline G & 271,630 & 93,670 & 0.4 & 4.5 \\
\hline G & 271,680 & 93,690 & 0.8 & 4.0 \\
\hline G & 271,720 & 93,720 & 0.7 & 3.1 \\
\hline G & 271,760 & 93,740 & 0.5 & 3.8 \\
\hline G & 271,810 & 93,760 & 0.6 & 4.0 \\
\hline G & 271,850 & 93,780 & 0.6 & 3.6 \\
\hline G & 271,890 & 93,810 & 0.8 & 3.1 \\
\hline G & 271,940 & 93,830 & 0.5 & 3.3 \\
\hline G & 271,970 & 93,860 & 0.9 & 2.5 \\
\hline G & 272,020 & 93,870 & 0.7 & 2.8 \\
\hline G & 272,060 & 93,900 & 0.6 & 2.6 \\
\hline G & 272,100 & 93,930 & 0.8 & 2.0 \\
\hline G & 272,150 & 93,950 & 0.6 & 2.2 \\
\hline G & 272,190 & 93,980 & 0.6 & 1.2 \\
\hline G & 272,240 & 94,000 & 0.5 & 2.2 \\
\hline
\end{tabular}


Appendix 2. A, Stage of Worden Pond and B, stage of Tucker Pond and water levels in a pond-bottom piezometer, 2006-2008 (location of measurement sites shown on figure 3), South Kingstown study site, southern Rhode Island.
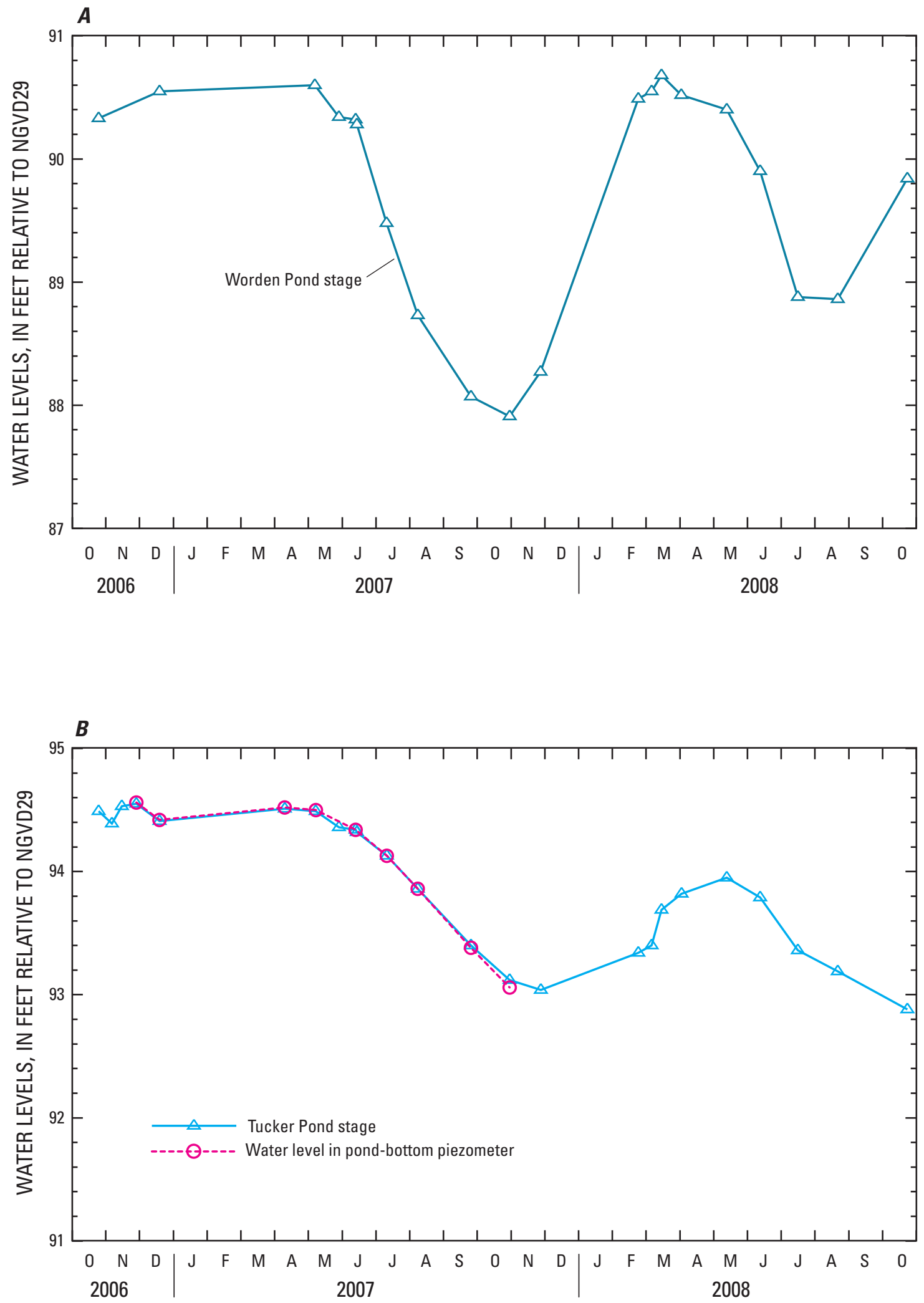
Appendix 3. Streamflow measurements made at partial-record sites (location of partial-record sites shown on figures 3 and 20), South Kingstown and Charlestown study sites, southern Rhode Island.

[USGS, U.S. Geological Survey; latitude and longitude in degrees, minutes, and seconds; $\mathrm{mi}^{2}$, square mile; $\mathrm{ft}^{3} / \mathrm{s}$, cubic feet per second; $\mu \mathrm{S} / \mathrm{cm}$, microsiemens per centimeter; ${ }^{\circ} \mathrm{C}$, degrees Celsius; --, no data]

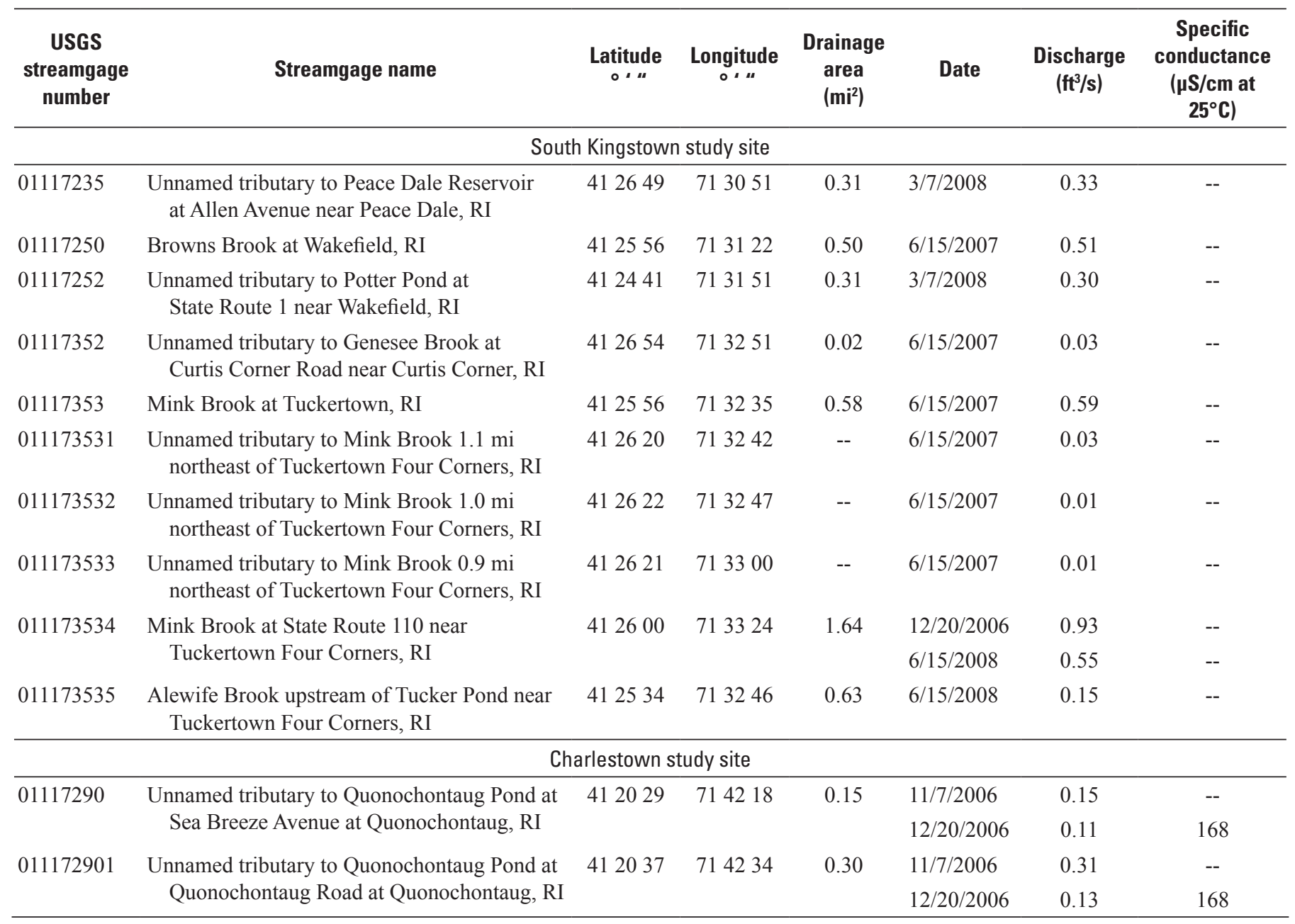


This page has been left blank intentionally. 
Prepared by the Pembroke and Weat Trenton Publishing Service Centers.

For more information concerning this report, contact:

Director

U.S. Geological Survey

Massachusetts-Rhode Island Water Science Center

10 Bearfoot Road

Northborough, MA 01532

dc_ma@usgs.gov

or visit our Web site at:

http://ma.water.usgs.gov 


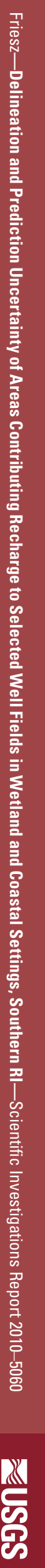

8 Printed on recycled paper

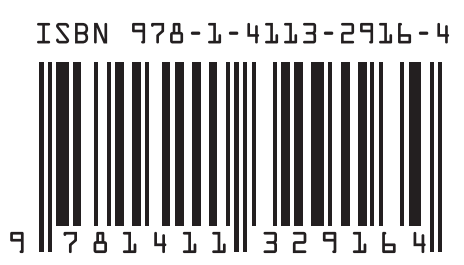

